

Department of Molecular Biology

Faculty of Sciences

Universidad Autónoma de Madrid

\title{
NANOG at the exit of pluripotency: \\ new roles in the gastrulating mouse embryo
}

\author{
Julio González Sainz de Aja. BSc Biology \\ Doctoral thesis directed by Dr. Miguel Manzanares Fourcade \\ CNIC, Madrid 2018
}



I hereby certify that JULIO GONZÁLEZ SAINZ DE AJA has carried out the experimental work leading to his $\mathrm{PhD}$ thesis entitled "NANOG at the exit of pluripotency: new roles in the gastrulating mouse embryo" under my supervision at the Centro Nacional de Investigaciones Cardiovasculares-CNIC in Madrid.

I also declare that the work presented is novel and of great importance in the field, and of sufficient quality to merit to be presented in order to obtain a PhD degree by the Universidad Autónoma de Madrid.

Madrid, $11^{\text {th }}$ of May 2018

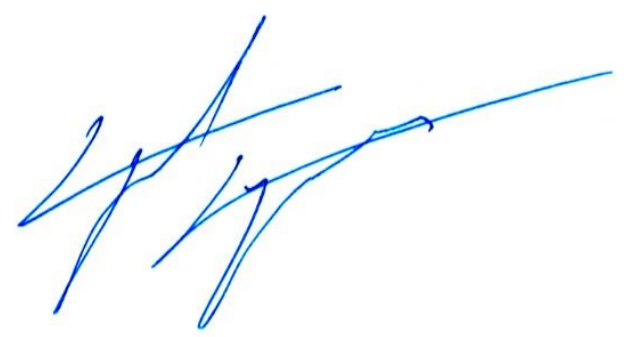

Miguel Manzanares

Area of cell and developmental biology

Centro Nacional de Investigaciones Cardiovasculares-CNIC

Melchor Fernandez Almagro, 3

28029 Madrid, Spain

tel: (34) 914531200 , ext. 3109

fax: (34) 914531304

mmanzanres@cnic.es

https://www.cnic.es/es/investigacion/genomica-funcional 



ACKNOWLEDGEMENTS 



\section{ACKNOWLEDGEMENTS}

Esta tesis ha tenido infinitos brazos, muchas piernas y varias cabezas trabajando en ella, y aunque los nombres de esas personas no aparezcan en la portada de esta tesis, en mi cabeza están todos los nombres de aquellos que han hecho que este trabajo merezca la pena ser publicado.

Miguel, has sido un jefe maravilloso. Muchas gracias por acogerme en tu laboratorio como lo hiciste. Por cogerme de la mano o dejarme volar cuando lo he necesitado. Nunca podré devolverte el esfuerzo que le has puesto a que yo aprendiera lo necesario para llevar a cabo este proyecto. Gracias también por dejarme hablar alto y claro siempre que he querido. Gracias por escucharme incluso cuando hablaba bajito y confuso. Si hay algo que tengo que reprocharte es que nunca voy a encontrar otro jefe que esté a tu altura. Has dejado el listón demasiado alto. Gracias por mostrarme lo que es la ciencia de verdad y dejarme disfrutarla como un niño en una juguetería. Igual no vas a echar de menos que te interrumpa todo el tiempo en tu despacho, pero yo lo voy a echar de menos cada día. Espero que me dejes molestarte por mail todas las veces que no podré hacerlo llamando a tu puerta. También tengo que agradecerte que me empujaras a hacer estancias (cierto que yo no puse ninguna resistencia) y cursos sin descanso, me han valido muchos nuevos colegas, compañeros y amigos, y por supuesto muchas experiencias nuevas tanto científicas como personales.

Cuando entré en el laboratorio la gente era muy distinta a la que hay ahora, pero me acuerdo mucho de todos. Eva, gracias por acompañarme los primeros días y por estar atenta a cada cosa que necesitaba o que ignoraba, tus consejos me sirvieron para empezar con buen pie y seguro de mí mismo. Luis, fuiste mi compañero de bench durante bastante tiempo, te agradezco tu paciencia, que soy consciente de que la ponía a prueba cada día. Gracias por perdonármelo todo. Gracias Inma por compartir tus conocimientos y aportar cada día con tus consejos. Gracias Elena, tu paso por el labo me ha hecho ser mejor científico y persona.

Susana, ya no estabas en el labo cuando llegué, pero como si lo estuvieras. Fuiste mi postdoc personal para todo lo que necesité y una muy buena amiga. 
Gracias por todos los consejos, por explicarme que también puedo estar disconforme, por enseñarme a tener filtro (claramente quien más lo ha agradecido ha sido Miguel), por tu cariño, por todas las cervezas.

Melisa, desde antes de que te fueras del labo ya te estaba echando de menos, has sido siempre para mi esa persona sabia que sabía qué tenía que decir en cada momento, aunque fuesen palabras al azar, siempre decías lo que me hacía sentir mejor. Gracias por tu fuerza, tu ánimo y tus ganas. Gracias también por ser mi amiga, por quererme tal y como soy y por hacerme sentir necesario. De ti he aprendido muchísimo, gracias por enseñarme con el ejemplo a tener desenvoltura en las presentaciones de mis trabajos científicos.

Teresa, te admiro científicamente por encima de todo, pero el hecho de que compartamos gustos tanto dentro como fuera del mundo científico ha hecho que de mayor quiera ser como tú todo el rato. Gracias por estar ahí siempre, tanto estando cerca como lejos. Gracias por discutir conmigo todo lo discutible de ciencia and else. Tus constantes ganas de aprender y tu capacidad para maravillarte me hacen querer ser mejor científico cada día. Gracias por ser el mejor ejemplo. Y por Xoel, y por Bigott, y por las risas.

Aurora, fuiste la primera en acogerme en el departamento y, casualidades de la vida, acabaste en el laboratorio compartiendo proyecto conmigo. Muchas gracias por todas tus enseñanzas sobre MSC, me encantó compartir Nanog, canciones por youtube y pelis tristes contigo, pero sobre todo Nanog. Fue una aventura visitarte en tu nueva etapa de postdoc, espero que nuestros caminos se sigan cruzando.

Sergio, hemos seguido un camino infinitamente distinto aunque paralelo, desde que entramos en el labo casi al mismo tiempo (siempre serás tú el veterano). Gracias por estar ahí a cada paso. Ha sido todo un honor y un placer compartirlo contigo. Estoy orgulloso de poder decir que aunque somos diametralmente opuestos hemos conseguido construir una relación científica y personal casi perfecta. Va a ser duro tenerte lejos, pero ya tendremos tiempo de coincidir en el próximo destino. Gracias por todo tu apoyo (y por tus desacuerdos) tanto con la pipeta como con el paper en la mano. Quiero que sepas que gran parte de la culpa de que este trabajo haya salido adelante es 
tuya. Gracias a tu buena planificación y a tu capacidad de trabajo he podido hacer experimentos que sólo no me hubiera ni planteado. Te estaré siempre agradecido.

Hector, lo nuestro fue un flechazo científico, y no puedo estar más feliz de haber podido compartir contigo todo este camino, desde el master hasta la lectura de la tesis. Has sido el perfecto compañero a cada paso. Gracias por todas las horas discutiendo ciencia o analizando resultados codo con codo, como si tu proyecto fuera el mío y el mío tuyo. Gracias por los experimentos secretos de fin de semana y por los consejos buenos y a tiempo. Hemos trabajado mucho pero los findes de juegos después del labo compensaban las horas pipeteando.

Claudio, has estado ahí casi desde el inicio, y no solo me has enseñado a ser cuidadoso y meticuloso, sino que te has esforzado por razonar conmigo cada protocolo y has trabajado conmigo como si fueramos un ser con cuatro manos. Muchas gracias por tu apoyo y todos los experimentos. Gracias también por defenderme cuando me tenías que defender y por ser justo y paciente. Han pasado muchas cosas desde que empezamos en el labo, pero tu sabiduría sólo ha crecido. Gracias por compartirla.

Isa, ya sabes que no te puedo estar más agradecido. Tu capacidad de trabajo nos inspira a todos en el labo, y nos empuja a darle más duro cada día. Eres un pilar del labo en el que todos nos apoyamos, pero yo te tengo que dar las gracias por estar ahí para mi, en las duras y en las maduras. Tu esfuerzo ha sido indispensable en esta tesis y por eso te agradezco cada valioso minuto de tu tiempo (y han sido muchos minutos...). Mil millones de gracias por todos los experimentos en los que has puesto la misma ilusión que yo, y en los que no te has rendido nunca. Serás siempre un ejemplo a seguir para mi. Aquí quiero hacer un inciso y agradecer también a Fernando, a Inés y a Clara por ser compresivos cuando sales del labo a las mil por algún experimento importante. Fernando muchas gracias por cuidar a Isa y apoyarla, me encanta veros juntos. Inés, cuando crezcas, espero que tu madre te hable de las cosas malas y buenas de la ciencia, para que puedas elegir objetivamente qué ser de mayor. Miedo me da que con la ilusión que le pone tu madre a la ciencia te metas en 
este mundo de cabeza, sin pensarlo mucho... Que la ciencia es muy sacrificada! Clara, de momento yo tengo claro que de mayor vas a ser artista, así que no me preocupa que oigas a tu madre hablar de CRISPR y de mutaciones guays, porque para mí que vas a ser una estrella de los escenarios, pero si no es así, lee el consejo que le doy a tu hermana. Os voy a echar mucho de menos a las dos. Espero veros crecer cada vez que vuelva a España, pero sobre todo espero ver crecer a vuestra madre en la ciencia. Es una de las científicas más valientes que conozco, se merece todo lo bueno.

Raquel, desde que entraste en el labo demostraste ser una persona muy dispuesta a aprender cosas nuevas, independientemente de los obstáculos que se presentaran en tu camino. Eres un ejemplo de resiliencia. Muchas gracias por esforzarte tanto, has conseguido que el labo sea un lugar mejor. Aunque nos cuesta mucho arrastrarte fuera del labo siempre es un placer disfrutar de tu presencia.

El labo fue cambiando poco a poco y empezó a entrar sangre fresca. María Lopez fue una sorpresa muy grata. María eres lo más, no cambies nunca. Tu manera de pensar en ciencia out of the box pero resolutiva nos encantó desde el principio. Gracias por tu sinceridad (“...pero esto sirve para algo?”). Eva nos dio la vida con sus ganas de aprender bioinformática. Ojalá no te hubieras ido nunca, te seguimos echando de menos. Te deseo toda la suerte del mundo. Gracias por toda la ilusión por nuestros proyectos. Nos la contagiaste desde el principio. Gonzalo, el input que me has dado durante esta tesis no tiene precio, pero no solo te tengo que agradecer eso, sino también tu desparpajo para hablar de ciencia y lo que no es ciencia. Lo haces todo más fácil.

Y de repente el labo dio su mayor cambio cuando llegaron Mariajo, Jesús y Alba. Y más adelante Antonio, Claire, Sara, María, Javi, Marta y Marcos. Fue un cambio definitivamente a mucho mejor. Vosotros no seréis conscientes del cambio, pero estoy seguro de que me creeis. Gracias infinitas por ponerle piernas y coco a todos los proyectos del labo con vuestras contribuciones.

Mariajo, fuiste nuestra primera postdoc real y te estaré eternamente agradecido por ello y por las ganas que le pones no sólo a tus proyectos sino a los de todo el labo. Espero que la ciencia te regale momentos tan buenos como los que te 
mereces. Tu visión de la vida, tan distinta de la mía me ha hecho crecer mucho como persona, espero que nuestros debates no acaben aquí. Te voy a echar de menos.

Jesús, te quiero y te respeto a partes iguales. Eres una persona brillante que me ha regalado momentos muy buenos tanto dentro como fuera del labo. Espero que nuestros caminos no dejen de cruzarse nunca, muchas gracias por todas tus ideas, las discusiones, y tu pragmatismo. Muchas veces me hace falta pasar por tu filtro para ver los obstáculos a los que me enfrento desde fuera. Gracias por hacérmelos ver bajo tu perspectiva. Siendo consciente o no me has ayudado a cada paso.

Alba, me ha encantado estar expuesto a tu forma de pensar. Creo que eres una científica excelente, con las preguntas adecuadas, y sobre todo, con una mirada crítica admirable. Muchas gracias por cada aportación y por arrimar el hombro siempre que ha sido necesario.

Claire, you are a very special scientist and singer, I hope everything goes however you like, because you deserve that and better. I know you know, but I really hope you can make it back into the lab. It will be much better with you in it. Thank you very much for your hard work and your clever points. You made better persons out of all of us.

Antonio L, fuiste todo un descubrimiento en el labo. Espero poder seguir disfrutando de tu presencia para siempre. Muchas gracias por abrirme los ojos a la cultura underground más molona ever. Virutas!

Antonio B, ya sabes que te estaré eternamente agradecido por todo el sudor y lágrimas (de risa?) que le has puesto a este trabajo. Esta tesis tiene un pedacito tuyo. Gracias por dejarme enseñarte lo que sé, y por atreverte a saltar y volar solo. Eres un valiente, no dejes de serlo nunca. Gracias también por las cenas, y por las discusiones científicas.

Sara, espero que en tus nuevas etapas aprendas tanto como has aprendido y nos has hecho aprender a los demás con tu trabajo. Muchas gracias por tu paciencia explicándonos variaciones y desviaciones. 
María, ha sido todo un lujo conocerte (otra postdoc genial en el labo!). Muchas gracias por todo el input y la discusión. Eres tan guay que ya solo por no poder ser tu colega más tiempo me da pena irme justo ahora del labo. Muchas gracias por inyectar de energía todo el labo. Espero que todo te vaya genial.

Javi, me ha encantado poder coincidir contigo en el labo. Es un gusto trabajar contigo, espero que sigas aprendiendo y disfrutando de la ciencia como hasta ahora.

Marta, acabas de llegar y ya has revolucionado el laboratorio con tu pasión. Las ganas que le has puesto ya han dado sus frutos y aquí me tienes flipando contigo. Muchas gracias por cada pregunta, cada observación. Has hecho de este labo un lugar mejor.

Marcos, eres un grande en todos los sentidos, espero que todo te vaya genial, y que la ciencia te trate bien, porque te lo mereces. Muchas gracias por hacérnoslo pasar tan bien tanto dentro como fuera del labo. De momento me consta que este laboratorio te ha marcado, espero que haya sido para bien.

I have been lucky enough to do a lot of stages in different labs. For this again I have to thank Miguel, but I also would like to thank the people who have open the doors of their labs and make me feel welcomed and at home.

For this reasons I want to thank Tristan Rodriguez, who taught me how to dissect and cultivate E5.5 embryos. Every morning he would go to the animal facility and bring me uterus for me to practice. You also allow me in your lab meetings and make me feel part of your lab, I will be forever grateful. In the lab Barbara Pernaute helped me out with the immunos on these early stages as well as showed me really good music. Thank you Barbara also for the discussions about epi stem cells and Nanog vs Brachyury. Aida Di Gregorio taught me one of the most important lessons: "a la ciencia hay que echarle piernas". Thank you Aida for all your advice.

When I first arrived to Takashi Hiiragi's lab in EMBL I was so excited to carry on a project that finally did not came out as expected, even so Takashi, you encourage me to pursue different approaches, always claiming that I could do as I dimmed necessary, as it was my project. Thank you for believing in me and 
for giving me the opportunity to work in such great scientific environment. From your lab I can't forget Laura Panavaite, who had to take care of my mouse colony, and Jean-Leon Maître and Ritsuya Niwayama, who were always eager to discuss science with me and whose friendship during those long summer I will never forget. From that time at EMBL I have to thank as well the technical support I received from Vladimir Benes and his unit and Alexis Pérez. Thank you both for your patience and the discussion. While in the EMBL guest house, I met amazing people with whom I still enjoy talking about projects and science. Thank you Jules, Jeremy and Justine. You made my stage at the EMBL more enjoyable and fruitful, and way less stressful that it should have been. Pierre, with the time you became a good friend, I hope the ocean won't take that away from us. Thank you for all the interesting scientific questions you are always asking, it makes my brain work at full capacity.

I would have never expected the good vibes I found when I first arrived to Jenny Nichols' lab. The whole Cambridge is a vibrant and interesting scientific community waiting in a pub around the corner, beer at hand. For that vibes I specially have to thank Carla Mulas, Kevin Chalut, Ayaka Yanagida, Tim Lohoff, Stanley Strawbridge, Tuzer Kalkan, Amy Li, Nicholas Bredenkamp, Masaki Kinoshita and Lawrence Bates. From all of you guys I learnt a lot. Thank you for all the scientific conversations and input, I was floating in science with you and I enjoyed it a lot. Especially I have to thank Carla and Ayaka, who helped me out a lot from finding reagents to protocols and for sitting with me to talk about all the projects I was interested in. It meant the world to me. Ken, I won't forget the effort you put in having the crosses set up for my experiments, thank you very much for that. Jenny, you have patiently taught me how to dissect all the periimplantation stages. It is amazing to see you at work and I feel very lucky to have witnessed all of it. Thank you very much for taking me in and for all your precious time teaching me and discussing with me. You are an amazing teacher.

Thanks to my stage in Jenny Nichols lab (and because she is so encouraging and helpful) I met a lot of incredible scientist and was able to discuss my project over and over. I have to thank for listening and for his input to Azim Surani (and for the mice as well, although they are still to be used). Alfonso Martinez Arias 
sat with me in numerous occasions to discuss about mine and other projects, for that many many thanks.

Jenny once came with me to meet Bertie Göttgens. From that meeting in which I tried to convince him that my project rocked, a collaboration sprout out. Thank you very much for letting me convince you and allowing me to use your resources. Thank you Wajid Jawaid for all your input, your analysis and your patience teaching me how to do single cell experiments and analysis. You are the best! Also thank you Fernando Calero, you made me feel at home.

Gracias Manolo por nuestras reuniones anuales, de ti he aprendido a sacar el máximo partido a las historias y a hacerme buenas preguntas. Gracias también por dejarme colaborar estrechamente con Daniela. Daniela mil gracias por todo tu input, por tu tiempo y por tu ilusión en mi proyecto.

Gracias Ángela por estar desde mi primer poster en un congreso internacional interesándote por mi proyecto. Ha sido un honor poder interactuar de congreso en congreso contigo, gracias por tus siempre interesantes preguntas, y gracias por acceder a ser parte de mi tribunal de tesis.

En el CNIC no solo la gente del labo ha sido importante en esta tesis, sino que gente de todos los departamentos del CNIC, de las unidades técnicas y del animalario han sido cruciales para mi desarrollo como científico y para este proyecto. Frank y Merche, nadie podría haber cuidado de las colonias como vosotros. Os agradezco infinito vuestros cuidados, vuestra paciencia y vuestra capacidad de organización e improvisación. Os voy a echar mucho de menos. Junto a ellos tengo que dar las gracias también a Antonio, Eva, Raquel, Isabel, Santi, Rubén y Edu, por hacer mi paso por el animalario cada vez más fácil.

Antonio de Molina y Roisin, muchas gracias por todo el tiempo invertido en mis muestras, lo habéis hecho con tanto cuidado y dedicación como si fuera vuestra tesis.

Gracias también a Raquel y a Javi por los largos ratos irradiando ratones, se hacía mucho menos pesado gracias a vosotros. 
Fátima, Carlos y Manuel, habéis seguido de cerca mi trabajo en el labo y me habéis ayudado en cada paso. Muchísimas gracias por vuestros análisis, por los ratos enseñándome a analizar mis datos, y por el tiempo dedicado a discutir mis proyectos. He aprendido mucho de vosotros, no lo olvidaré (por la cuenta que me trae...) nunca.

Giovanna, Nines, Paco y Elisa: habéis sido mi faro en cultivos durante toda mi estancia en el labo. Ya sabéis que os lo agradeceré siempre, pero quería que quedara constancia de no solo lo trabajadores que sois, sino de lo majos y de vuestra capacidad para ayudar a mil personas lloronas a la vez. Ha sido un placer poder trabajar con vosotros.

Elvira y Vero, me habéis enseñado todo lo que sé de microscopía de epifluorescencia, confocal, multifotón y análisis de imágenes. Muchas gracias por todo vuestro tiempo. Bajar a microscopía, aparte de ser muy divertido, ha sido siempre asistir a una de mis clases favoritas. Gracias por hacer de la óptica algo entretenido.

Sergio, Alberto y Ana, desde las qPCRs a las secuenciaciones más difíciles habéis hecho que todo pareciera factible. Muchas gracias por cuidar de mis muestras como si fueran vuestras. Gracias por vuestro conocimiento transmitido y por arriesgaros a secuenciar locuras.

Raquel, Mariano, Jose y Elena, muchísimas gracias por todos vuestros consejos, por asistirme de urgencia cuando se atascaba el citómetro o cuando no sabía qué le pasaba al Canto. Vuestra paciencia me ha hecho aprender muchísimo más de lo que hubiera esperado con mi uso esporádico de los citómetros. Estoy muy contento de haber trabajado con vosotros, y muy triste porque a ver dónde encuentro un equipo como el vuestro! Muchas gracias a María por ese casting tan maravilloso que ha hecho.

Gracias Juande, Chema y Luis Miguel. Vuestra pericia con el microinyector ha hecho de esta tesis un trabajo mejor. Gracias por hacer lo necesario para que mis experimentos fueran un éxito. 
Marta Ramón, gracias por cada petición cumplida, por cada momento dedicado a los papeles y a la intranet que muchas veces me superaban y tú hacías llevaderos.

Teresa Casaseca, gracias a que existes no hemos perecido de sequía de reactivos, y hemos tenido una logística casi perfecta en el labo. Muchísimas gracias por todos los pedidos con urgencia que te hemos pedido y que seguimos pidiéndote. Muchas gracias también por tu actitud, nos alegra el día cada vez.

Gracias Sonia por estar siempre dispuesta a sacar dinero de donde hiciera falta para que pudiera terminar experimentos. Gracias por trabajar tan duro para que nuestros papeles estuvieran siempre en regla. Llenas de energía buena el labo cada día, te voy a echar de menos.

Gracias a Ángel, a Elena, a Jose a Loli y a Eva por ser tan majos y flexibles cada día. Por llamarnos a todos por nuestro nombre y hacernos sentir en casa, alimentándonos así de bien. Especialemente a Ángel, qué hubiéramos hecho sin ti en la cafetería? Tu rapidez nos permite a todos empezar el día más o menos a la hora.

Ana y Luis, vuestro trabajo siempre en la sombra ha sido importante cada día, muchas gracias por hacerme más fácil todo desde el principio.

Aun sabiendo la de aventuras que me esperan fuera del CNIC, me muero de pena al pensar que mi tiempo aquí se acaba, y que voy a tener que despedirme de todos vosotros, que habéis hecho mi estancia aquí tan especial y tan disfrutable tanto científicamente como personalmente.

Tengo que agradecer en especial a Joan Isern, gracias a tu input mi tesis es ahora lo que es. Espero poder seguir discutiendo ciencia contigo en los próximos años.

Miguel Torres y Rui Benedito, muchas gracias por todas vuestras preguntas, tanto en congresos, como en seminarios o en el pasillo. Me han hecho crecer un poco más como científico. 
Simon Mendez Ferrer, junto con Tristán Rodriguez fue parte de mi comité de tesis, a él quiero agradecerle todas las veces que se reunió conmigo para examinar el fenotipo de mis embriones. Muchas gracias por tu input.

Nadia, muchas gracias por escuchar todo mi proyecto y discutirlo conmigo, gracias por dejarme colaborar a manos llenas con Héctor.

Andrés Hidalgo, en el tramo final de la tesis has sido de gran ayuda, tanto con tus observaciones como con tus reactivos y con las colaboraciones en general (gracias por dejarme trabajar con Itziar).

Itziar, has sido una de mis últimas colaboradoras. No solo te estoy agradecido por tu ayuda pipeteando, sino por enseñarme nuevas y desconocidas formas de organizarme el trabajo, por tu humor hasta altas horas de la noche trabajando y por todos los análisis y la discusión. Ha sido un placer tenerte cerca, tanto dentro como fuera del labo.

Rocío, lo bueno de que ya te hayas ido es que no me tengo que despedir de ti. Aun así, te echo mucho de menos, tanto para reirme como para llorar, pero sobre todo para discutir de ciencia, aunque no te gustara hacerlo fuera del labo y a veces te tuviéramos que obligar, siempre has sido una interlocutora genial para hablar de experimentos presentes y futuros. Muchas gracias por tu paciencia, tu ilusión y tu asertividad.

Son muchísimas las personas que han hecho de mi trabajo en este centro algo por lo que merecía la pena levantarse cada mañana. Os tengo que dar las gracias a tantos... Gaetano, Guille, Lao, Dani Mateos, Giulia, Sara Cogliati, Marta Roche, Samu, Maca, Briane, Guislaine, María Galardi, Andrés Sanz, Laura, Cris del Carmen, Noelia, Cova, Cris Clavería, Sandra, Andrés, Cris2 y Cris3, Dani, Juan, Silvia, Marta, Jose, Geo, Iván, Fran, Jorge Alegre, Elías, Carla, Ángel, Diana, Sara (muchas gracias por estar ahí en los últimos papeleos de la tesis), Carles, Jose, Javito, Ana, Verdiana, Laura, Dimitri, Jesús, Paula (me has aguantado los últimos estertores de la tesis, bendita paciencia), Eli... A todos vosotros mil millones de gracias. Especialmente tengo que agradecer las visitas de Maca y Briane al bench, a salvarnos del pipeteo. Muchas gracias Briane por compartir conmigo tu gusto por la literatura. Ha sido 
un placer compartir campo de investigación contigo. Jose (Manu), mil gracias por todo, ha sido un honor compartir cañas, ciencia, pelis y switch contigo. Ana Paredes, eres una de las mejores personas del CNIC, te lo mereces todo, muchas gracias por todo tu esfuerzo en cada paso. María Galardi, no soy místico pero en tu caso creo que lo has hecho todo tan bien que el universo te lo tiene que devolver con creces, muchas gracias por compartir cada reactivo y protocolo. Javito, hay pocas personas en el CNIC que me hayan sacado una sonrisa cuando estaba desesperado con algún experimento duro de pelar. Tú eres una de ellas, muchas gracias por las risas dentro y fuera. Cris del Carmen, de tu mano he conocido algo tan inolvidable como la feria de Sevilla, muchas gracias por enseñarme a bailar sevillanas y por invitarme a tu casa y a tu caseta, espero que nos veamos en más ferias. Carles, de ti aprendo cada día. Muchas gracias por todo lo que nos das, espero que algún día sepamos devolvértelo. Andrés Sanz, gracias por lanzarte de cabeza a colaborar conmigo, y por enseñarme a inyectar peces. Verdiana, aunque ya te has ido, irme yo del labo significa tenerte aún más lejos, pero nunca olvidaré el tiempo (corto) que coincidimos en el tiempo y el espacio, todavía me dura la resaca. Gracias por tu humor y por tus ganas. Eli, tus ganas de vivir y tu ilusión se me contagian cada vez que estoy contigo, muchas gracias por transmitirme todo lo bueno. Sara y Alberto, carambola del destino haberos conocido. Me alegro mucho de haber tenido tanta suerte. Dani Mateos, empezamos siendo colegas de cigarro y conversación de epigenómica, y acabaste siendo padrino de mi boda (por supuesto seguimos hablando de interacciones de factores de transcripción). A ti no solo te debo el interés por la bioinformática y la conformación del ADN, sino que me presentaste a la que es mi compañera de vida. No tengo palabras para poder agradecerte eso y todo lo demás. No voy a saber qué hacer sin ti.

Giulia, mi otra madrina, muchas gracias por todos los consejos, científicos y de otro calado que me has dado a lo largo de toda la tesis. Gracias también por ser tan buena anfitriona tanto en Madrid como en Londres.

A todo tu grupo de master le debo una cantidad de consejos infinita, lo que da la experiencia. Muchas gracias Lucía, Miguel, Lara, Inés, David, Pilar, Alfonso, Edu, Flo (la que más sabe de becas en USA), Marta, Alejo... Muchas gracias a 
todos por vuestros consejos con la tesis, con las becas, con los labos de postdoc.... Os debo varias cenas.

A los que debo también muchas cenas es al grupo maravilloso de científicos en Boston como Kike, Javi, Olga, Mariam... y por supuesto Alejo, Edu y Flo otra vez, que hicieron de mi búsqueda de postdoc algo fácil y entretenido. Mil gracias a todos!

Mi familia ha jugado un papel muy importante durante toda la tesis. Mamá, gracias por hacer de mí la persona que soy hoy, por sentirte orgullosa de mi cuando lo necesitaba. Gracias por todo el esfuerzo físico y mental que le has puesto a mi educación como científico, como músico y como persona. Gracias por los desayunos entre semana, por esperarme fuera del conservatorio, por llevarme a los mejores teatros y conciertos. Gracias por abrirme a un mundo de posibilidades donde, si he elegido bien, ha sido gracias a ti.

Tía Ayi, has sido como una madre para mí, muchas gracias por todos los cuidados y las preocupaciones, pero también por mandarme a la mierda cuando me lo merecía. Has sido un ejemplo a seguir desde que era pequeño. No sería nadie sin tus consejos.

Papá, has tenido que soportar no verme casi nada durante la tesis, espero que haya valido la pena. Muchas gracias por estar ahí cada vez que te he necesitado, o incluso sin hacerlo.

Abuela Luisa y abuelo Julio, muchas gracias por preocuparos por mi tesis, gracias por sentiros orgullosos de mi cuando ni yo sabía muy bien qué estaba haciendo. Me habéis dado fuerzas para seguir sin descanso.

Abuela Nena y abuelo Tomás, ya no estáis aquí pero os tengo muy presentes cada día, en parte gracias a mamá y a los tíos. Obviamente sin vosotros no estaría aquí, pero también quiero pensar que se me pegó algo de vuestra inteligencia, diligencia y sentido del humor. Os quiero mucho y no os olvido.

Tío Carlos, Luis, tía Ana, Elena, primos Laura, Diego y Juan muchas gracias por vuestro cariño y por vuestro apoyo. Gracias por estar ahí en cada paso. 
Con vosotros he aprendido a hablar de mi proyecto más abiertamente, sin tecnicismos. Espero que vengáis a verme siempre que podáis.

Sandra, he crecido contigo, admirando cómo podías aprenderte "esos tochos" de memoria. Muchas gracias por estar ahí siempre. Muchas gracias por seguir cultivando mi cultura cada vez. Soy mejor persona gracias a ti.

Tía Marisa, Carmen y tío Angel, muchas gracias por interesaros en mis proyectos. Gracias también a mis tíos Juancarlos, José y Asun y a mis primas Almudena, María, Irene y Virginia, habéis crecido conmigo y hemos aprendido juntos, espero que sigamos haciéndolo.

Gracias también a mi familia política. Mamen, muchísimas gracias por tus consejos y por tu ayuda en cada viaje Boston (y en todo lo demás). Gracias por compartir tu casa y tu familia conmigo. Gracias Celia, Lucía y Marina por dejarme disfrutar de Cris, aunque soy consciente de que el ojo de Sauron que todo lo ve sigue mirando de cerca, os quería decir que "yo tengo un moco, lo saco poco a poco". Gracias a Carmen, Manu, a Carlos e Isa, a Mariano y a los telerines en general, por interesarse por la tesis y por meterme prisa. Un empujón a tiempo siempre se agradece. Muchas gracias a Julio y a Maribel, aprecio mucho vuestro apoyo desde el inicio de la tesis. Gracias también a Pedro y a Rosa, así como a Elena, que me habéis acogido en distintas etapas de la tesis, siempre con una sonrisa. También gracias al resto de los Gutierrez Ríos, por tener siempre palabras de aliento.

La gente de la universidad ha contribuido en gran medida a que esté hoy aquí. En especial me gustaría agradecer a Mónica de la Fuente, que fue mi primera jefa en el laboratorio y que supo guiarme en los distintos proyectos que realicé en su labo. Gracias lanire y Oskarina por ser buenas compañeras y mejores amigas. Gracias Lorena, fuiste mi primer paso en la ciencia, la primera persona que me enseñó lo que es pipetear de verdad. Te estaré siempre agradecido. Gracias Carmen y Julia por hacer de mi estancia en el labo un lugar ideal para trabajar. Juncal, Virginia, Lore, Carmen, Bego, Ana, Irene, Chonch, habéis sido mi pilar fundamental durante la carrera, espero que sigáis siendo una referencia para mi siempre, tanto personal como laboralmente. Virginia, muchas gracias por hacerme sentir en casa en tu casa, gracias por tener mi 
cepillo de dientes, por hacer los deberes conmigo, por aguantarme y dejar que te aguante, gracias por venirte de aventura conmigo a Pisa. Juncal, has sido mi ancla a la realidad durante todos estos años entre tanta gente competitiva. Muchas gracias por ser mi amiga, tu amistad no es cosa menor, es cosa mayor. Lore, has sido un ejemplo para mi, mucha suerte en tu nueva etapa, aunque no la vas a necesitar. Muchas gracias por cuidar de nosotros como lo haces. Dónde estaríamos sin ti?

Gracias a Jose y a Camino que me metieron en el grupo de teatro he podido convertirme en el amigo de personas muy especiales que me han acompañado de caña en caña, miércoles a miércoles cada año de tesis, por ello muchísimas gracias a Mera, Ana, Myriam, Pecha, Raquel, Joyu, Amorfo, Sevi, Costa y Chechi.

Además de este grupo genial de amigos, me llevo a las personas que hicieron que el teatro y los juegos de mesa se convirtieran en dos pilares de mi entretenimiento y mi pasión. Muchas gracias Bea, Gago, Anita, Fagot, Antón, Charlie, Paloma... ha sido un honor teneros como amigos, sois todos gente tan inteligente y tan maja que a veces es abrumador teneros al lado. Sois los mejores, no os voy a perder de vista. Artistas!

Tengo unos pocos amigos que han crecido conmigo a los que tengo que agradecer haberme hecho la persona que soy hoy. Muchas gracias por todo, mis Tolis. Gracias a Marta (que en la distancia te preocupas de nosotros como si estuvieras cerca), Irene (porque has sido un apoyo enorme durante la tesis, allí donde nos llevaran nuestros pasos), Alba (que tiene un arte especial para hacer de cualquier situación algo disfrutable, y que es una artista), Dani (has sido mi compañero de carrera y lo seguirás siendo siempre, sé que puedo contar contigo, aunque no me sepas explicar qué es una matriz compleja), Yago (eres un ejemplo de superación para todos, estoy muy orgulloso de lo que has conseguido), Clara (porque cada día quiero ser más como tú), Rosa (por fin, ya está aquí, mi tesis. Gracias por estar presente en cada paso, por preocuparte y animarme aunque tú ya tuvieras suficiente con lo tuyo), Tanya (muchas gracias por todo el amor, sigo sintiéndome tan seguro cuando estoy contigo como si estuviera con mi prima de zumosol), Natalia (porque eres un 
rayo de sol, tu alegría nos contagia a todos y nos ayuda a seguir adelante), Jose (Luna! Luna! Ven aquí! Eres un ejemplo a seguir, y yo te seguiré allí donde vayas), Bea (mi compañera de fatigas, la incansable, gracias por cuidarme como tú solo sabes. Con un trago de cocacola arreglas el mundo a cualquiera)... Estoy orgulloso de poder considerarme vuestro amigo.

Cris, gracias por acompañarme en toda esta aventura. Por quererme, apoyarme y disfrutar de mi ciencia conmigo, como yo lo he hecho con la tuya. Gracias por todas las discusiones científicas y las no científicas. Me has hecho crecer como persona y como científico mucho más de lo que yo hubiera podido solo. Eres una científica brillante y tu fuerza me inspira cada día. Gracias no solo por esto, sino también por lo demás: por pipetear conmigo hasta las mil para que pudiera salir antes del labo, por enseñarme a usar el citómetro, por darme los mejores consejos en cultivos, por prepararme la cena cuando yo no podía con mi vida, por tener las mejores palabras en los peores momentos, por emborracharte conmigo, por bailar la vida conmigo como si se tratase de un protocolo bien articulado. Te debo tanto, que ya sé que nunca saldaré mi deuda. Gracias por el amor por la ciencia, y por el que me das a mí. 
SUMMARY 



\section{SUMMARY}

Developmental biology studies the processes by which a cell divides and differentiates to generate a full functional organism.

Up to the onset of gastrulation, cells from the embryo remain pluripotent, but precisely at this stage they differentiate towards mesoderm, endoderm, ectoderm and primordial germ cells. Pluripotency factors maintain uncommitted cells of the blastocyst and embryonic stem cells in culture in the pluripotent state. However, little is known about the role played by these factors during later development, despite their being expressed in the postimplantation epiblast. At this stage, progenitors of the first hematopoietic cells in the mouse arise in the early mesodermal progenitors in the posterior-proximal region of the epiblast, but the mechanisms that specify primitive blood cells are still largely unknown. At the same time, the embryo polarizes and asymmetry arises with the formation of the anterior-posterior axis.

Using a dual transgene system for controlled expression at postimplantation stages, we found that NANOG, a pluripotency factor crucial for pluripotency maintenance, blocks primitive hematopoiesis in the gastrulating embryo, resulting in a loss of red blood cells and downregulation of erythropoietic genes. Accordingly, Nanog deficient embryonic stem cells are prone to erythropoietic differentiation. Moreover, Nanog expression in adults prevents the maturation of erythroid cells. By analysis of available data for NANOG binding during stem cell differentiation and CRISPR/Cas9 genome editing, we found that Tal1 is a direct target of NANOG.

We also found that Nanog represses anteriorization of the epiblast. By analyzing NanogKO ES cell RNAseq during naïve to primed transition and single cell RNAseq of gastrulating mouse embryos, we discovered that Nanog directly downregulates Pou3f1, that codes for a transcription factor important for anteriorization and neural development. Our results show that Nanog exerts crucial functions at the exit of pluripotency, and that it regulates primitive hematopoiesis and anteriorization of the embryo by directly repressing critical lineage specifiers. 



\section{RESUMEN}

La biología del desarrollo estudia los procesos por los cuales una célula se divide y se diferencia hasta generar un organismo completo y funcional.

Hasta el momento de la gastrulación, las células del embrión permanecen pluripotentes, pero a partir de este estadio embrionario se diferencian a mesodermo, endodermo, ectodermo y células del primordio germinal. Los factores de pluripotencia mantienen indiferenciadas las células madre en cultivo y del epiblasto embrionario, sin embargo, poco se sabe de su función más tardía, pese a seguir expresados más allá del epiblasto pluripotente y de la gastrulación. En este estadio los progenitores de las primeras células hematopoyéticas aparecen a partir de los progenitores tempranos del mesodermo y al mismo tiempo, el embrión se polariza dando lugar a la formación del eje anteroposterior.

NANOG es un factor de pluripotencia crucial para el mantenimiento de ésta en el blastocisto y células madre. Usando un modelo de ratón doble transgénico mediante el cual podemos controlar la expresión de Nanog en estadios de postimplantación, hemos descubierto que Nanog bloquea la hematopoyesis primitiva y genes específicos de anteriorización del embrión durante la gastrulación. Como consecuencia, los embriones que expresan Nanog de manera ubicua son anémicos y tienen defectos craneofaciales. Además, la expresión ectópica de Nanog en médula ósea de adulto tiene como consecuencia el bloqueo madurativo de los eritrocitos. Mediante el análisis de data previos de sitos de unión al genoma de NANOG en células madre, junto con edición del genoma mediante CRISPR/Cas9, hemos demostrado que la expresión de factores críticos en la especificación de estos linajes, Tal1 y Pou3f1, se regulan negativamente de manera directa por NANOG. 



\section{INDEX}

SUMMARY

$\begin{array}{lr}\text { INTRODUCTION } & 17\end{array}$

1. From one to many 20

2. Gastrulation $\quad 21$

$\begin{array}{ll}2.1 \text { The road to gastrulation } & 21\end{array}$

2.2 The onset of gastrulation 23

3. The genetic control of pluripotency and its dismantling 25

3.1 The exit of pluripotency 26

$\begin{array}{ll}3.2 \text { Exit of pluripotency in vivo } & 27\end{array}$

3.3 Pluripotency factors after implantation 28

4. Emergence of hematopoiesis in the mouse embryo 30

5. Anterior patterning and neural fate 32

$\begin{array}{ll}\text { OBJECTIVES } & 33\end{array}$

$\begin{array}{ll}\text { MATERIALS AND METHODS } & 39\end{array}$

1. Animal model 41

2. Transient transgenic analysis and line generation 41

3. Culturing embryos at the onset of gastrulation 43

4. Chimeras generation 43

5. RT-qPCR assays 43

6. Flow cytometry 44

$\begin{array}{ll}\text { 6.1 Transplant assays } & 45\end{array}$ 
7.2 Anterior neural differentiation 46

7.3 Naïve to primed pluripotency differentiation 46

8. In situ hybridization 47

9. RNAseq analyisis 47

9.1 NanogKO ES cell RNAseq $\quad 47$

9.2 Analysis of gene set in Nanog ${ }^{K O}$ versus control 48

9.2 Analysis of scRNAseq of E6.5 49

9.3 RNAseq of Nanog ${ }^{\text {tg }}$ at E7.5 49

9.4 Intersection analysis $\quad 49$

$\begin{array}{ll}\text { RESULTS } & 51\end{array}$

1. Embryonic defects induced by Nanog in the E9.5 mouse 53

1.1. A mouse model for controlled Nanog gain-of-function 53

1.2 Nanog induces loss of blood and neural defects in the embryo 53

2. A role for Nanog in primitive haematopoiesis 52

2.1. Nanog blocks erythropoiesis in developing mouse embryos

2.2. Nanog does not affect developing vessels 56

2.3. Flow cytometry analysis reveals a specific effect of Nanog on 57 erythroid differentiation

2.4. Nanog downregulates the expression of key erythroid determination genes in the embryo 
4. Loss of Nanog enhances hematopoietic differentiation of ES cells

4.1. Colony forming units assay reveals increased potential for erythroid differentiation in Nanog ${ }^{K O}$ ES cells

4.2. Hematopoietic genes are expressed regardless of the delay in Brachyury expression during differentiation of $\mathrm{Nanog}^{-/}$ES cells

5. Effects of Nanog gain-of-function on haematopoiesis in the adult mouse

5.1 Blockade of adult erythrocyte maturation by Nanog

5.2. Differentiation of megakaryocyte-erythroid progenitors is blocked by Nanog

5.4. Nanog-expressing MEPs are outcompeted by the host in bone marrow transplants

6. Tal1 is a target of Nanog at gastrulation

6.1. Nanog expression is mutually exclusive with that of Tal1 in the nascent mesoderm

6.2. A distal NANOG-binding element represses Tal1 expression in the embryo

7. Regulation of anterior fates in the epiblast by Nanog

7.1 Lack of Nanog upregulates anterior neural genes at the exit of naïve pluripotency

80

7.2 Integration of different RNA-seq data reveals Pou3f1 as a primary target for repression by NANOG in gastrulating mouse embryos

7.3 Nanog expression impairs neural differentiation in vitro

7.4 A distal NANOG-binding element represses Pou3f1 expression in the posterior epiblast

DISCUSSION

CONCLUSIONS

BIBLIOGRAPHY

PUBLICATIONS 



\section{LIST OF ACRONYMS}

AGM

A-P axis

AVE

BFU-E

CFU

CFU-E

CFU-G

CFU-GEMM

CFU-GM

CFU-M

CFU-MEP

CFU-Mk

CMP

dox

DVE

EMT

EPC

EpiLC

Ery-P

ES cell

ExE

GMP

GRN

HSC

ICM

$\mathrm{Kb}$ aorta-gonad-mesonephros región

anterior-posterior axis

anterior visceral endoderm

burst forming unit erythroid (CFU)

colony forming unit

erythroid progenitor cells (CFU)

Granulocyte (CFU)

granulocyte, erythroid, macrophage, and megakaryocyte progenitor (CFU)

granulocyte-macrophage progenitor (CFU)

Monocyte (CFU)

megakaryocyte-erythroid progenitors (CFU)

Megakaryocyte (CFU)

common myeloid progenitors

doxycycline

distal visceral endoderm

epithelial to mesenchymal transition

ectoplacental cone

epiblast like cell

primitive erythroid colonies

embryonic stem cell

extraembryonic ectoderm

Granulocyte-Monocyte progenitors

gene regulatory network

hematopoietic stem cells

inner cell mass

Kilobases 
LSK

MEP

Nanog $^{-/ 2}$

Nanog ${ }^{\text {tg }}$

NSC

PE

PGC

RBC

sgRNA

$\mathbf{T}$

TE

tetO

TF

TGC

tracrRNA

VE
Lin-Sca1+cKit+, hematopoietic stem cells enriched population

megakaryocyte-erythroid progenitors

Nanog knockout ES cells

TetON transgenic model for Nanog ectopic expression

neural stem cells

primitive endoderm

primordial germ cells

red blood cells

guide RNA

Brachyury

trophectoderm

doxycycline responsive promoter

Transcription factor

trophoblast giant cells

Trans-activating crRNA

visceral endoderm 
A todas las mujeres, que luchan cada día por lo que a los hombres nos viene dado.

En especial a tres luchadoras:

A Carmina, a Dori y a Cris. 

"All sorts of things can happen when you're open to new ideas and playing around with things"

Stephanie Kwolek 



\section{INTRODUCTION}





\section{INTRODUCTION}

Developmental biology has been studying the embryonic growth and differentiation of different species of plants and animals from the egg to the individual for the past century. From the observation that cancer cells and embryo cells differentiate and grow differently by Calkins in 1908 or the mixed culture of embryonic tissue and tumor of Rous in 1911, the discovery of the organizer by Mangold and Spemann in 1927, going through the realization that induction of the epiblast was done by the endoderm in chicken by Waddington in 1933, or the discovery that preimplantation embryos could be cultured outside the uterus of the mother by Runner in 1947 up to the generation of embryonic stem cells out of blastocyst outgrowth by Gardner and Beddington in 1988. All these discoveries have in common that all are important breakthroughs in development and have pushed forward the understanding of life as we know it (Calkins, 1908; Gardner and Beddington, 1988; Mangold and Spemann, 1927; Rous, 1911; Runner, 1947; Waddington, 1933). This requires the dynamic interplay of many cellular processes coordinated in space and time. Scientific research in the developmental area pursues the elucidation of the general principles and mechanisms underlying the cellular organization in developing organisms. The breakthroughs in developmental biology have reshaped our society, for instance through the introduction of new technologies such as the in vitro fertilization. Developmental sciences have as well yielded huge technological advances in science, such as chimeras and transgenic mouse line or embryonic stem (ES) cell generation (Gardner, 1968; Martin, 1981a). However, scientific advances in developmental biology have also contributed to other fields such as cancer (Nieto, 2013), evolution (Conway Morris, 2000), neurosciences (England et al., 2006), immunology (Martín-Gayo et al., 2017), genetics (Duboule and Morata, 1994) or adult stem cell biology (Koo and Huch, 2016). 


\section{From one to many}

One of the most important scientific questions of our time that developmental biology has been trying to address for the past century is: how can just one cell give rise to a whole organism? However, we are still far from having an answer (Fig1).

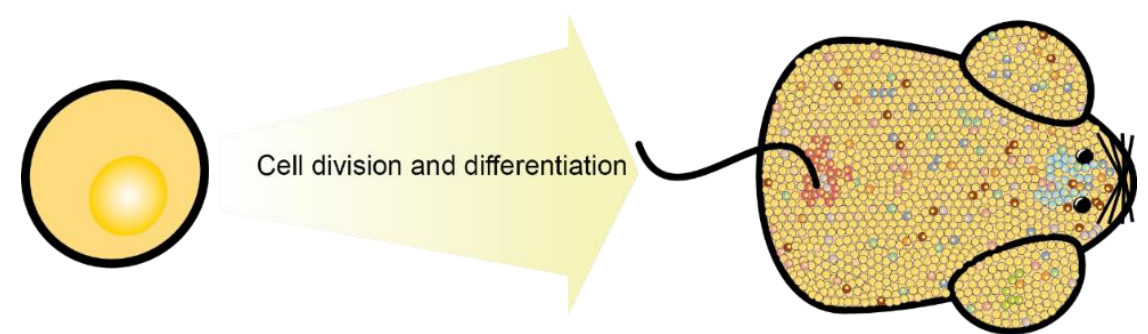

Figure 1. From one cell to a whole grown and differentiated organism: On the left one cell (zygote) that will give rise to a whole organism composed by many different types of cells (indicated with cells of various colours) on the right

Conrad Hal Waddington was one of the first to elaborate a theory on how a cell acquires a specific fate through differentiation, providing a paradigm that developmental biologists still use to visualize the differentiation potential of a cell. He imagined competence (competence being the ability of a cell to respond to inducing -differentiation- signals) as a cell in a state of instability. Induction would push the cell towards a specific developmental pathway from this point of instability. If the cell does not receive the inducing signal, it would self-differentiate according to its own tendencies. He represented this theory with the epigenetic landscape (Baedke, 2013; Fig 2).

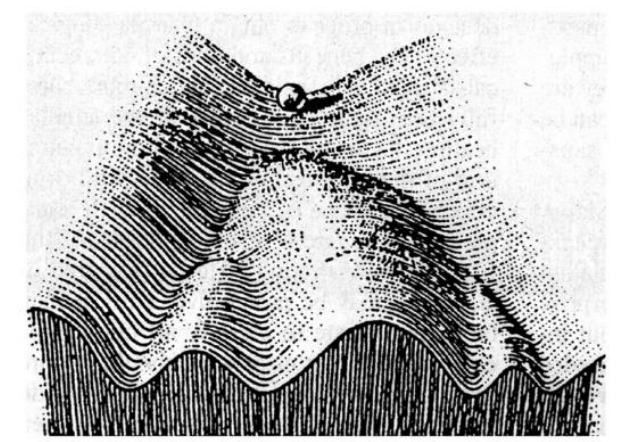

Figure 2. Epigenetic landscape of a differentiating cell as envisioned by Conrad Hal Waddington: Picture was first published in the book Organisers and genes (Waddington, 1940) 


\section{Gastrulation}

The time in which cells from the embryo have to undergo important differentiation processes in animals is the gastrulation stage. As Lewis Wolpert put it, "It is not birth, marriage or death, but gastrulation which is truly the most important time of your life". In this stage, undifferentiated cells give rise to the different germs layers that will generate all different tissues in the organism.

Currently there are animal models well suited for the study of gastrulation mainly because at this stage they can be observed without much interference or handling, such as the African clawed toad Xenopus laevis, or the zebrafish Dario rerio (Heisenberg et al., 2000; Winklbauer et al., 2001), where gastrulation process can be observed in the microscope. However, one of the animal models that have been used extensively for studying the gastrulation stage has been the mouse. This is mainly because of its evolutionary resemblance to humans, both being mammals, its breeding capabilities, and its small size.

\subsection{The road to gastrulation}

For a mouse embryo, it takes 6 days since fertilization to reach the onset of gastrulation. To arrive to this stage from the fertilized egg, an equilibrium between pluripotency -that forces the cells to grow undifferentiated- and differentiation that drives the generation of new tissues- must exist (Fig 3).

Once the egg is fertilized it undergoes a series of divisions until the stage of 8 to 16 cells, when the so called morula is compacted (Pratt et al., 1982). From the two cell stage (when maternal to zygotic transition occurs) through the next two division rounds, each blastomere retains full competence to develop into any cell, embryonic or extraembryonic. This ability of the cell to give rise to any tissue is called totipotency (Boroviak and Nichols, 2014; Morgani and Brickman, 2014). The first morphological differences appear during compaction, in which cells increase their cellular adhesions. Subsequent divisions -from 16 to 32 cells- result in polarized cells in the surface of the embryo and apolar cells in the inner region. At this stage, a large fluid-filled cavity is formed within the embryo called blastocoel. Blastocoel expansion reshapes the embryo and finishes with the formation of the blastocyst (Chisholm et al., 1985; Motosugi, 2005). At the early 
blastocyst stage, we already observe two different populations: the trophectoderm (TE) that are epithelial cells on the outer layer of the embryo, which surround the second population, a group of cells called inner cell mass (ICM) that are sitting in contact with the TE. The ICM will give rise to the embryo proper and the yolk sac, while the TE will differentiate to form the majority of extraembryonic tissues (mainly the placenta). The ICM at this stage conserves the ability to give rise to any cell type in the embryo except for the placenta, therefore becoming pluripotent, instead of totipotent.

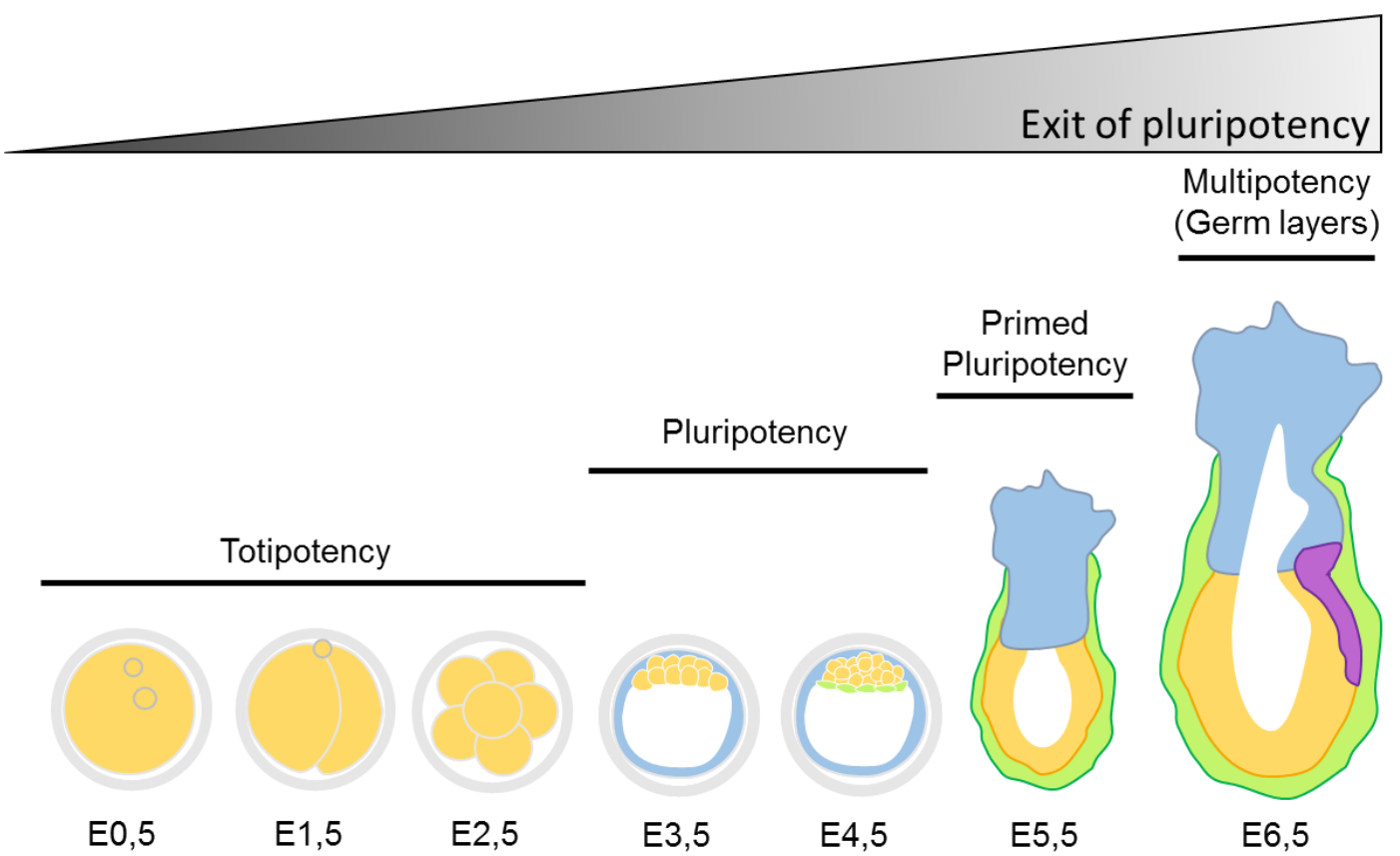

Figure 3. Stages in early mouse embryonic development: From egg fertilization to gastrulation. In orange the embryo, trophectoderm and derivatives in blue, primitive endoderm and derivatives in green, mesoderm in purple.

One day later, at embryonic day 4.5 (E4.5), the primitive endoderm (PE) that eventually will give rise to the visceral endoderm (VE), an extraembryonic group of cells that are involved in patterning and protection of the embryo, differentiates from the ICM. Between the PE and the TE a group of cells called epiblast still retains pluripotent capabilities and will give rise to all of the tissues of the embryo (Gardner, 1982).

After hatching from the zona pellucida -a glycoprotein layer surrounding the plasma membrane of oocytes (Mainland, 1932)- the blastocyst implants in the uterus of the mother through the mural TE, which are the trophoblast cells 
opposite to the ICM pole. Implantation requires a complex set of interactions between the embryo and the uterine epithelium, involving different proteases, adhesion molecules and signaling events (Aplin and Ruane, 2017).

The first definitive cell type that differentiates from the TE upon implantation are the trophoblast giant cells (TGC). The TGCs cover the embryo with the exception of the polar TE, which are the trophoblast cells in direct contact with the epiblast. The polar TE gives rise to two different cone shaped structures: the extraembryonic ectoderm (ExE), in direct contact with the epiblast, and the ectoplacental cone (EPC), that is located proximal to the ExE and that mediates early interactions with the maternal endometrium.

At the same time, the epiblast acquires a cylinder shape with cells arranged in a pseudo-stratified epithelium, and is covered by the VE. The ExE establishes a complex crosstalk with the epiblast that will be necessary for anterior-posterior axis establishment, germ cell formation and gastrulation of the epiblast (Beck et al., 2002a; Feldman et al., 1995; Yoshimizu et al., 2001).

\subsection{The onset of gastrulation}

Formation of the primitive streak is the morphological cue for gastrulation. Proper location of the primitive streak demands the previous establishment of the anterior-posterior (A-P) axis in the epiblast. The A-P axis arises from the opposite signals from the ExE (BMP4 and NODAL activation) and the VE, first distal (DVE) and later anterior (AVE) with the nodal agonist Cer1 and Lefty1. For Nodal activation, its dephosphorilation is fundamental. Furin and Pcsk6 (protein convertases), both secreted in the ExE, dephosphorylate Nodal in the epiblast (Beck et al., 2002b). These signaling events, together with Wnt3 that triggers the expression of Brachyury (T) and Fgf8 make gastrulation possible (Fig4). 


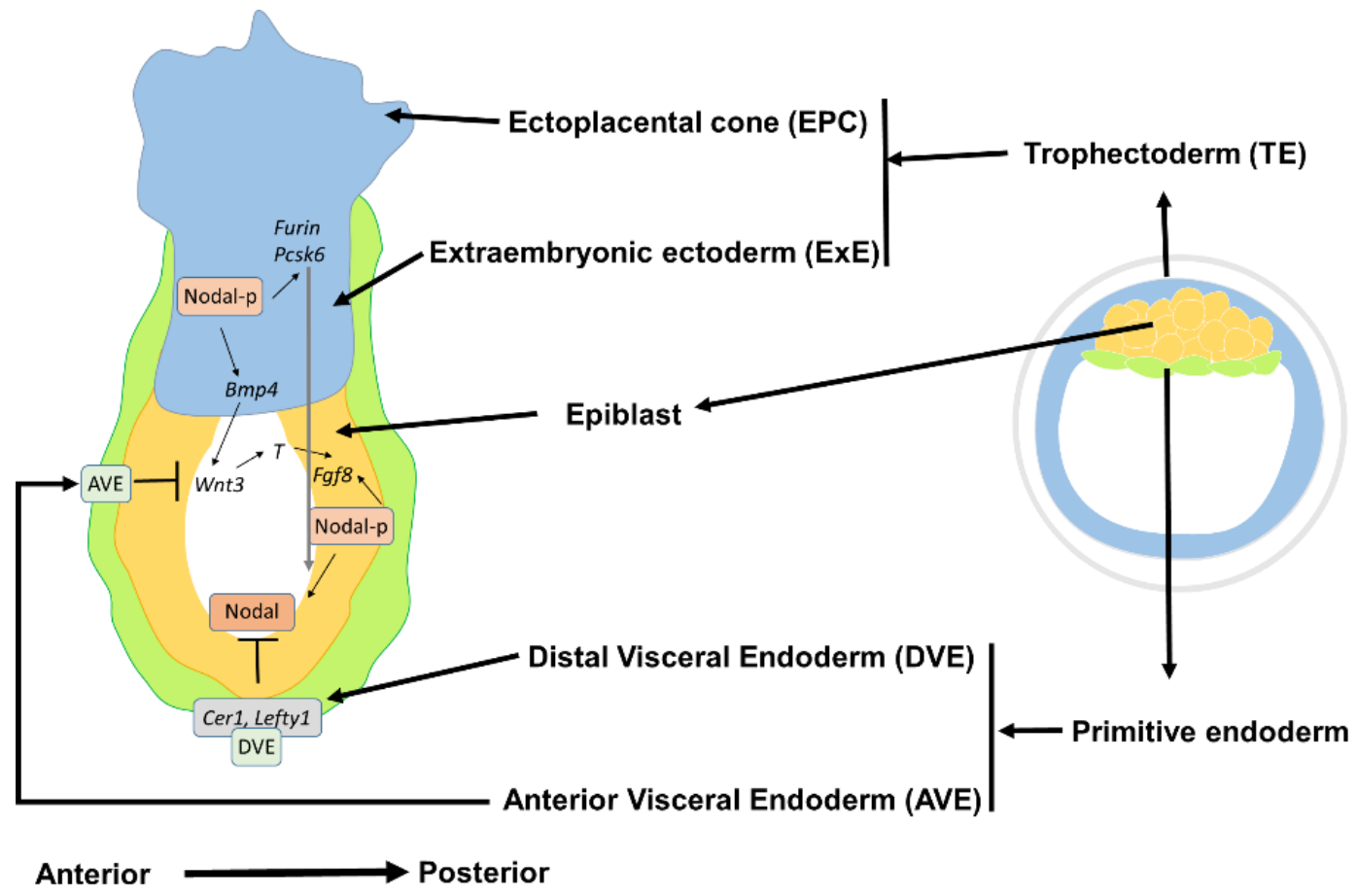

Figure 4. Signaling and gene expression in A-P axis formation: On the left a representation of an E5.5 embryo with schematic signaling for A-P axis formation; arrows indicate activation, blunt arrows indicate repression. On the right, an E4.5 blastocyst from which the different structures commented in the figure develop.

During gastrulation, cells that were attached to each other in the epiblast by adhesion molecules such as E-Cadherin lose said adhesions and separate from the epiblast undergoing an epithelial to mesenchymal transition (EMT) to migrate through the primitive streak. Snail genes code for key factors that regulate this primary EMT by downregulating E-Cadherin and promoting motility (Nieto et al., 1994; Thiery et al., 2009). The previous location of these cells in the epiblast predict which tissues they will give rise to (Padrón-Barthe et al., 2014; Tam and Beddington, 1987; Tam and Zhou, 1996). From proximal to distal, precursor mesoderm cells ingress the primitive streak in an orderly fashion. First blood, then allantois, cardiac, lateral plate and presomitic mesoderm. Finally the last cells that delaminate from the epiblast will differentiate into definitive endoderm (Scialdone et al., 2016; Fig 5). An important role here is played by the node, that acts to organize the body plan inducing the formation of posterior structures by producing Nodal. It is essential for mesoderm and endoderm differentiation (Tam and Beddington, 1987). Next to the node, at the node-streak border is where the neuromesodermal progenitors appear (Henrique et al., 2015). 


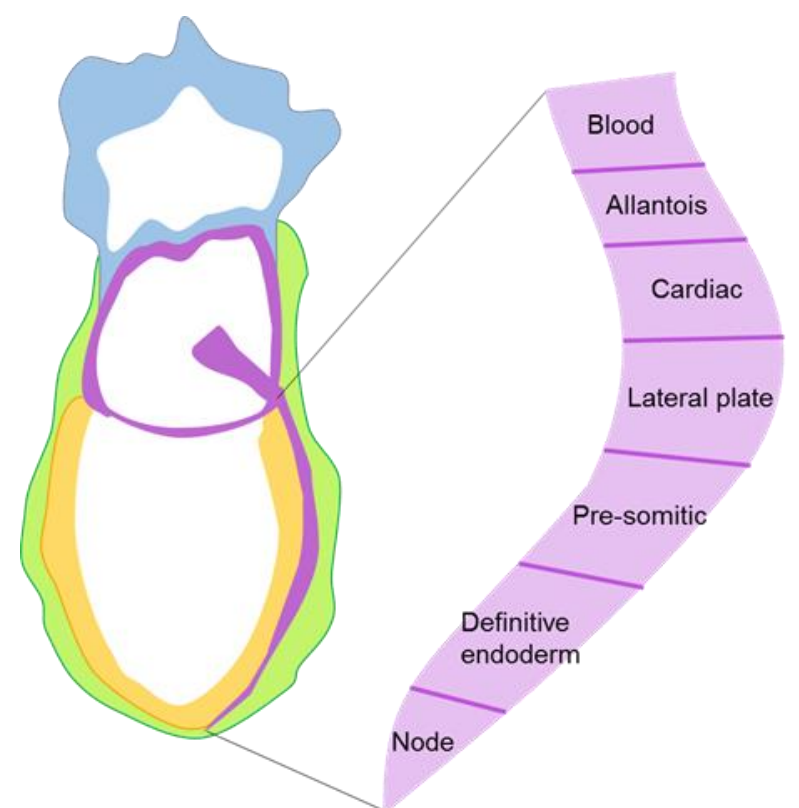

Figure 5. Mesoderm lineages distribution: Along the axis of the primitive streak in order from proximal to distal lineage specification

Up to the onset of gastrulation epiblast cells conserve the ability to give rise to any germ layer, although epigenetic and transcriptomic changes make them more prone to differentiate. Thus cells at this stage are considered to be in a state of primed pluripotency (Nichols and Smith, 2009a). Therefore, one of the most important processes that takes place during the first stages of embryo development is the exit from pluripotency, what allows these cells to differentiate down Waddington's epigenetic landscape.

\section{The genetic control of pluripotency and its dismantling}

Pluripotency is a steady state in which cells can self-renew and remain undifferentiated, retaining the capacity to give rise to any germ layer. This cell state is maintained thanks to an intricate network of genes that are tightly regulated by three main TFs: NANOG, OCT4 and SOX2.

NANOG is a constituent of the core set of transcription factors, together with OCT4 and SOX2, involved in establishing and maintaining embryonic pluripotency, both in the blastocyst and in embryonic stem (ES) cells in culture (Chambers and Tomlinson, 2009). ES cells were first obtained from blastocyst and cultured in teratocarcinoma stem cell conditioned medium (Martin, 1981b) 
and described as pluripotent cells able to form teratocarcinomas when injected into mice. Since then, ES cells have been used for chimeras generation, differentiation assays and xenograft implants. The instrumentalization of this ES cells relies on the understanding of the pluripotency gene network. This gene regulatory network (GRN) regulates pluripotency by repressing genes involved in differentiation and activating other genes important for pluripotency (Osorno et al., 2012a; Thomson et al., 2011) (Fig 6). Most importantly, it also leads the process of exiting pluripotency by responding to extrinsic and intrinsic signals and changing the regulatory regions and partners they bind to (Kalkan and Smith, 2014; Mohammed et al., 2017a; Pfeuty et al., 2018).

\subsection{The exit of pluripotency}

Although multiple studies have addressed embryonic stem (ES) cell differentiation (Mendjan et al., 2014; Radzisheuskaya et al., 2013; Thomson et al., 2011), the exit of pluripotency in vivo is still not well understood (Tam and Behringer, 1997). Most of the work has been done in the blastocyst, given that at this stage it is the first time a lineage choice occurs (Chazaud et al., 2006; Rossant and Tam, 2009; Yagi et al., 2007), and also because of the versatility and easy handling of preimplantation embryos.

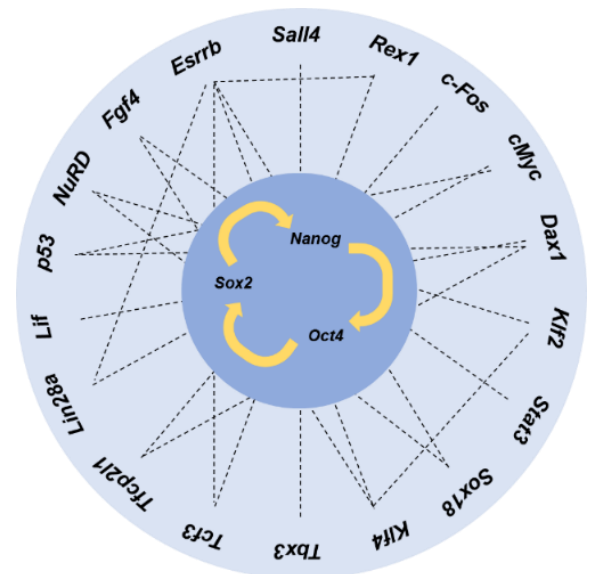

Figure 6. The pluripotency Gene Regulatory Network: Multiple genes regulate the activation and the maintenance of pluripotency in vivo and in vitro, and at its core SOX2, NANOG and OCT4 are in charge of regulating the process at a transcriptional level. This is a representation of the interconnections between genes instrumental for pluripotency instruction that at the same time are regulated by the core GRN (modified from (Parfitt and Shen, 2014)).

As we have discussed earlier, the dynamics of the core pluripotency GRN in vivo vary at different developmental stages of the early embryo, and these variations are actually the ones that configure the disposition of the exit of pluripotency. 
Rewiring of pluripotency GNR is fundamental for the exit of pluripotency (Aksoy et al., 2013). In ES cells, SOX2 and OCT4 bind together to most genomic regions, which are also frequently bound by NANOG (Chen et al., 2008; Marson et al., 2008). Changes in levels of expression of these TFs can induce a change of partners, what can also be due to novel factors being expressed or to changes in the chromatin accessibility of key loci (Navarro et al., 2012; Niwa, 2007). This is how TFs that previously worked together to maintain pluripotency are able to adjust their function to allow differentiation when changes in the cellular environment occur (Iwafuchi-Doi et al., 2011a). This has been proven to happen both in vitro and in vivo (Avilion et al., 2003). A good example of how this network is rewired at the exit of pluripotency is the selective influence of SOX2 in either OCT4 (Pou5f1) or OCT6 (Pou3f1). These TFs interact differently in ES cells and in differentiated multipotent neural stem cells (NSC): In ES cells SOX2 binds to OCT4 in the Sox/Oct motives, but in neural stem cells OCT6 and SOX2 bind to those motives on their own (Mistri et al., 2015), without interacting with each other.

\subsection{Exit of pluripotency in vivo}

The early blastocyst is a good example of how these dynamics are important for differentiation in vivo. In the inner cell mass (ICM) of the blastocyst the cells are in a pluripotent stage in which Nanog levels fluctuate from low Nanog to high Nanog expressing cells (Abranches et al., 2013). The cells that express low levels of Nanog are the ones that are able to differentiate and give rise to the primitive endoderm (Chazaud et al., 2006). The late blastocyst stage contains the primitive endoderm and the epiblast. In the epiblast, all of the cells hold highly expressed levels of Nanog, Sox2 and Oct4 and hence do not differentiate towards any lineage. How these epiblast cells escape pluripotency and the role of the core pluripotency factors in this process is largely unknown.

Therefore, in order to explore the exit of pluripotency towards different germ layers and tissues we need to study later stages of postimplantation development, when gastrulation takes place (Tam and Behringer, 1997). 


\subsection{Pluripotency factors after implantation}

Despite they key role of OCT4, SOX2 and NANOG in the preimplantation embryo and in ES cells to maintain cells in the pluripotent state, it is a fact that all three factors are expressed at later, postimplantation stages of mouse development, which suggest roles not directly related to pluripotency (Osorno et al., 2012b)

At E6.5, Sox2 is expressed in the anterior region of the epiblast and will remain expressed in the anterior neural region up to E9.5, when it gets restricted to specific neural structures. At E6.5 Nanog gets reexpressed in the posterior epiblast. In the proximal region is a key factor for the induction of PGCs, where it gets restricted at E8.0 while it disappear from the rest of the epiblast (Chambers et al., 2007a; Hart et al., 2004a; Zhang et al., 2018). On the other hand, Oct4 is expressed throughout the whole epiblast and continuously expressed up to E8.5, when it starts restricting to the posterior part of the embryo (Yeom et al., 1996) (Fig 7).

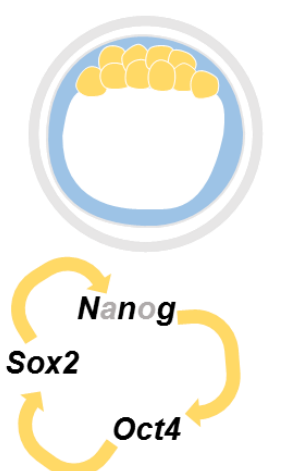

Early blastocyst

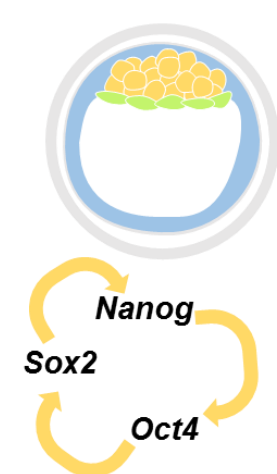

Late blastocyst
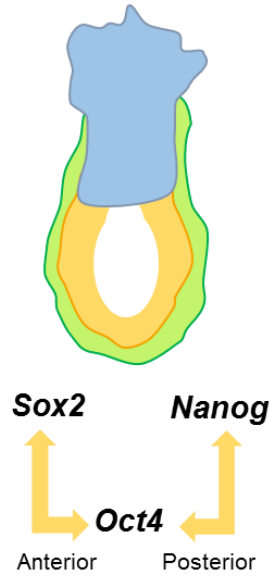

Early postimplantation

Figure 7: Pluripotency GRN during development: At the early blastocyst stage the levels of Nanog change from cell to cell of the ICM (Nanog in gray and black). In the late blastocyst all three transcription factors are highly expressed in the epiblast. After implantation Oct4 is expressed in the whole epiblast while Sox2 is restricted to the anterior and Nanog to the posterior epiblast.

To study the role of the different components of the pluripotency GRN the three core TFs have been knocked out (KO) of the embryo. In all three cases, the deletion is lethal at blastocyst stage (Masui et al., 2007; Mitsui et al., 2003a; Nichols et al., 1998). This precludes the analysis of possible postimplantation 
phenotypes. In order to address this issue, conditional KO lines have been generated. In the case of Oct4, mutants show proliferation defects at gastrulation (DeVeale et al., 2013). Sox2 conditional mutant embryos result in neural defects, with mild effects in brain development probably due to other Sox genes, such as Sox 1 and Sox3, that might compensate for Sox2 absence (Bylund et al., 2003; Ferri et al., 2013; Graham et al., 2003)

However, no conditional mouse line of Nanog deletion in the epiblast has been published yet. Interestingly, Nanog-deficient ES cells are still able to maintain pluripotency, although they are prone to differentiate (Chambers et al., 2007a). Nanog expression is turned off during implantation only to be re-expressed again at E6.0 in the posterior part of the embryo, were gastrulation will start later. This pattern gradually disappears and at E8.0 the expression of Nanog is restricted to the primordial germ cells (PGCs), were Nanog plays an important role in their differentiation and migration (Chambers et al., 2007a; Yamaguchi et al., 2009; Zhang et al., 2018) (Fig 8). Besides its function in the germline, there is little evidence for the role of Nanog in the postimplantation epiblast or in the gastrulating embryo.

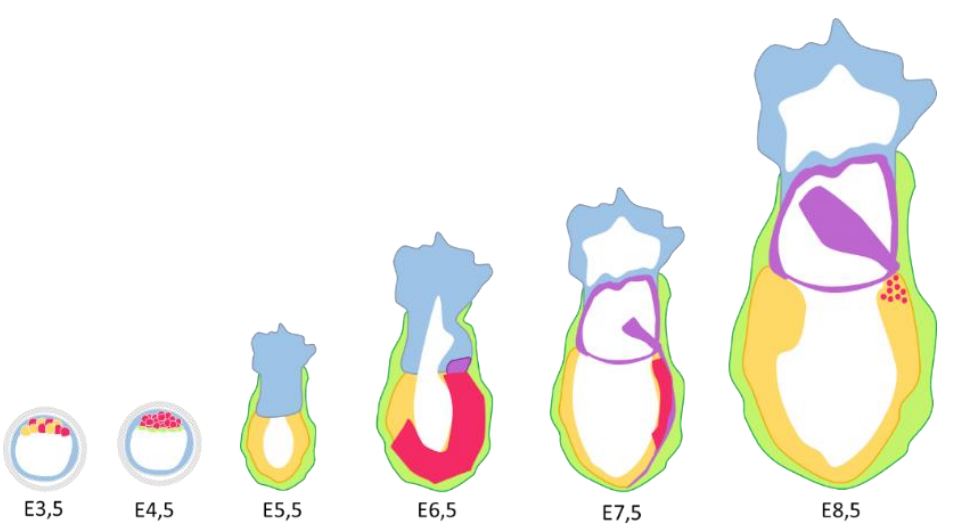

Figure 8: Nanog pattern of expression during development: Nanog expression is shown in red. Embryonic stages are indicated below embryos. Nanog is expressed at E3.5 in the ICM in a salt and pepper manner, and at E4.5 it is expressed in the whole epiblast. Expression turns off at E5.5, to be re-expressed at E6.5 throughout the posterior region of the epiblast. At E7.5 it is gradually downregulated until E8.0 when it is only expressed in the PGCs, where the expression is maintained until E12.5-E13.5. 
Since there is no conditional KO for Nanog in the epiblast, we decided to address the question of the role of Nanog during the gastrulation stage by using a TetON transgenic model (Nanog ${ }^{\text {tg }}$ ). This system has been successfully used to uncover a previously unsuspected role for Nanog in adult epithelia (Piazzolla et al., 2014). With this model in hand, we could express Nanog at will in defined time windows during postimplantation stages of mouse development. When we first extended Nanog expression from gastrulation up to E9.5 we observed two specific phenotypes: a complete lack of blood in the embryos, and consistent anterior neural defects (Results Fig 11). During this thesis work, we aimed to understand both processes and how they relate to the function of Nanog in the gastrulating embryo.

\section{Emergence of hematopoiesis in the mouse embryo}

Hematopoiesis first arise when diffusion of oxygen is insufficient for the maintenance of the growing embryo. Cells from the posterior epiblast are able to give rise to red blood cells during a very short period of time. The precursors of the first erythroid cells are already present at the initial stages of gastrulation, in the nascent mesoderm at the posterior end of the embryo (Huber et al., 2004; Lawson et al., 1991). Moreover, detailed fate mapping suggests that these cells are specified in the epiblast before gastrulation (Kinder et al., 1999; PadrónBarthe et al., 2014). In fact, there are allegedly two different precursors in the posterior epiblast: those that firstly ingress the primitive streak and that will give rise to red blood cells (RBC) and those that follow this first wave and give rise to endothelial cells as well as RBC, megakaryocytes and macrophages (PadrónBarthe et al., 2014; Scialdone et al., 2016). Hematopoietic precursors are specified after the determination of the early mesoderm from the epiblast, which is driven by the sequential action of the transcription factors encoded by Brachyury and Mesp1 and finally in the expression of FLK1 (encoded by Kdr), which marks most mesodermal cells at gastrulation (Pfister et al., 2007; Scialdone et al., 2016). Subsequently, primitive hematopoiesis progenitors start expressing a battery of lineage-specific transcription factor genes such as Tal1, Gata1, and Klf1 as they migrate to the extraembryonic region and generate the blood islands of the yolk sac (Baron et al., 2012; Doré and Crispino, 2011). 


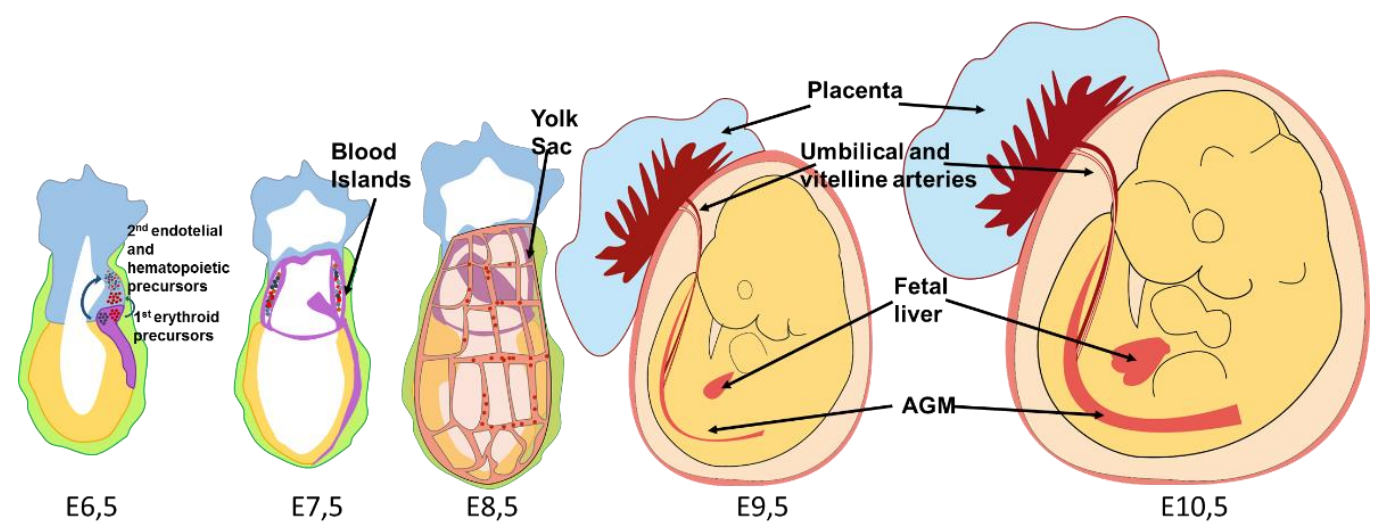

Figure 9: Hematopoietic development: Embryo in orange, ExE and placenta in blue, VE in green, hematopoietic sites in red. Arrows indicate anatomic sites of hematopoiesis during development.

The first erythroid cells are immature RBC with unique characteristics and are found only in the early embryo (Palis et al., 1999). They are much larger than definitive erythrocytes and express embryonic globins, and upon maturation they lose the nucleus as occurs with adult erythrocytes (Tober et al., 2008). Macrophages and megakaryocytes progenitors are produced as well at the first stages of primitive hematopoiesis (Tober et al., 2007) but they are indistinguishable from their definitive counterpart. At E8.0 erythro-myeloid progenitors rise and are able to produce mature erythrocytes and most myeloid lineages. At E9.5, B and T cells appear both in the yolk sac and the aorta-gonadmesonephros region (AGM; Yoshimoto et al., 2011). It is at this stage that resident macrophages are generated (Ginhoux and Guilliams, 2016). Since the first burst of erythroid cells occurs at E7.5, at E9.5 still most of the circulating RBC population derives from the primitive, first wave of hematopoiesis (Lux et al., 2008; Fig 9).

It is not until E10.5 that the first long-term hematopoietic stem cells (HSC) are generated (Medvinsky and Dzierzak, 1996). HSCs are produced in the major arteries of the embryo: AGM, and vitelline and umbilical arteries. Later they are also found in the placenta and yolk sac (de Bruijn et al., 2000; Gekas et al., 2005). HSCs migrate to the fetal liver were their numbers increase massively and by E16.5 they colonize the bone marrow, where they will engraft and stay during all the adult life. 
Since Nanog is highly expressed at E6.5 in the posterior region of the epiblast, which is when and where the first RBCs come from, we hypothesize that Nanog might be blocking the RBC lineage at E6.5, and that property of Nanog is echoed in the anemic phenotype of the E9.5 embryos.

\section{Anterior patterning and neural fate}

As we have described above, anterior-posterior axis determination of the mouse embryo relies on gastrulation, signaling from extraembryonic tissues, and morphological changes. However, studies in gastruloids have shown that ExE and AVE are not strictly necessary for triggering gastrulation in culture (Turner et al., 2017). Furthermore, growth of human and mouse ES cells on micro-patterned cultures have demonstrated that no shape cue is necessary for gastrulation or exteriorization (Deglincerti et al., 2016; Hemmati-Brivanlou and Melton, 1997; Morgani et al., 2018; Muñoz-Sanjuán and Brivanlou, 2002). Therefore, this evidence suggests that epiblast-intrinsic properties are responsible for driving anterior-posterior fates and neural specification, and not dependent exclusively on signaling processes driven by extraembryonic tissues.

Nevertheless, the precise timing of the regulation at a transcriptional level of anterior neural formation in vivo is still not fully understood. Transcription factors (TF) such as SOX2 have been identified as neural fate-promoting factors. Actually, it has been demonstrated that in chicken SOX3 repress Snail genes and vice versa for defining anterior and posterior territories. This is conserved in mice -which mechanism involves Sox2- and in human cancer cells (Acloque et al., 2011). The earliest TF expressed in postimplantation epiblast involved in anteriorization is Pou3f1, it is known to activate Sox2 in the epiblast and later in anterior neural differentiation (Zhu et al., 2014).

This, together with our observation that Nanog can interfere with the development of the anterior neural region, suggests that rewiring of the pluripotency gene regulatory network could also be at play during this process at gastrulation. 


\section{OBJECTIVES}





\section{OBJECTIVES}

The general objective of this thesis is to elucidate the role of Nanog at the exit of pluripotency.

The specific objectives addressed during this thesis work are:

1. To study the role of Nanog in hematopoietic differentiation by:

1.1 Investigating the effect of continued expression of Nanog in the embryo on hematopoietic differentiation at gastrulation.

1.2 Analyzing the hematopoietic differentiation potential of embryonic stem cells in the absence of Nanog.

1.3 Assessing the effect of Nanog gain-of-function in the adult bone marrow.

1.4 Identifying hematopoietic genes that could be direct targets of NANOG at gastrulation.

2. To study the role of Nanog in regionalization of the gastrulating embryo by:

1.1 Exploring the role of Nanog at the exit of pluripotency by analyzing the transition of naïve to primed embryonic stem cells.

1.2 Identifying putative targets of NANOG at this transition by integration of different transcriptomic analysis.

1.3 Analyzing genomic loci of selected target genes to look for NANOG responsive regulatory elements. 



\section{OBJETIVOS}

El objetivo general de esta tésis es esclarecer el papel de Nanog en la salida de la pluripotencia.

Los objetivos específicos desarrollados durante la tesis han sido:

\section{Estudiar el rol de Nanog en la diferenciación hematopoiética:}

1.1 Investigando el efecto de la expresión continua de Nanog en la diferenciación hematopoiética del embrión durante la gastrulación.

1.2 Analizando el potencial de diferenciación hematopoiética de células madre embrionarias en ausencia de Nanog.

1.3 Evaluando el efecto de la ganancia de función de Nanog en la médula ósea adulta.

1.4 Identificando genes hematopoiéticos que pudieran ser dianas directas de NANOG durante la gastrulación.

\section{Estudiar el papel de Nanog en la regionalización del embrión durante} gastrulación:

1.1 Explorando el papel de Nanog en la salida de la pluripotencia mediante el análisis transcripcional de la transición de células madre embrionarias naïve a diferenciadas.

1.2 Identificando posibles dianas de NANOG en esta transición mediante la integración de diferentes análisis transcriptómicos.

1.3 Analizando diferentes loci del genoma para buscar posibles elementos reguladores que respondan a NANOG. 

MATERIALS

AND METHODS 



\section{MATERIALS AND METHODS}

\section{Animal model}

We obtained the Nanog/rtTA mouse line (R26-M2rtTA;Col1a1-tetO-Nanog) (Piazzolla et al., 2014) from Manuel Serrano (CNIO, Madrid) and Konrad Hochedlinger (Harvard Stem Cell Institute). This is a double transgenic line that carries the M2-rtTA gene inserted at the Rosa26 locus and a cassette containing Nanog cDNA under the control of a doxycycline-responsive promoter (tetO) inserted downstream of the Col1a1 locus (Fig 10). Mice were genotyped by PCR of tail-tip DNA as previously described (Hochedlinger et al. 2005; Piazzolla et al. 2014). Mice were housed and maintained in the animal facility at the Centro Nacional de Investigaciones Cardiovasculares (CNIC, Madrid, Spain) in accordance with national and European Legislation. Procedures were approved by the CNIC Animal Welfare Ethics Committee and by the Area of Animal Protection of the Regional Government of Madrid (ref. PROEX 196/14).

Double-homozygote transgenic males were mated with CD1 females, which were then treated with doxycycline (dox) to induce the Nanog cassette by replacing normal drinking water with a $7.5 \%$ sucrose solution containing dox $(1 \mathrm{mg} / \mathrm{ml})$, with replacement with fresh solution after 2 days. For transgene induction in embryos to be harvested at E7.5, a single $100 \mu \mathrm{l}$ intraperitoneal injection of $25 \mu \mathrm{g} / \mu \mathrm{l}$ doxycycline was administered to pregnant females at E5.5, followed by dox administration in drinking water as above.

\section{Transient transgenic analysis and transgenic line generation}

For the generation of transgenic embryos, 7 weeks old F1 (C57BI/6xCBA) females were superovulated to obtain fertilized oocytes as described (Nagy et al., 2014). Females were injected with 5 units of pregnant mare's serum gonadotropin (PMSG, Foligon 5000) and 5 units of chorionic gonadotropin (Sigma) two days later, followed by embryo collection the next day. After 1 hour incubation, viable zygotes were microinjected into the pronucleus with commercially available Cas9 protein (30ng/ul; PNABio) and guide RNA (sgRNA; 25ng/ul; Sigma). All those components were previously hybridized to genereate ribonucleoprotein 
complexes. First we incubated 100ng/ul of Trans-activating crRNA (tracrRNA) and sgRNA 5 minutes at 95을 $\mathrm{C}$ and then 10 minutes at room temperature (RT). After that, we incubated them with the Cas9 for 15 minutes at RT, and stored at $4^{\circ} \mathrm{C}$. Injection buffer contains Tris $50 \mathrm{nM} \mathrm{pH7.4,} \mathrm{EDTA} 1 \mathrm{nM}, \mathrm{H}_{2} \mathrm{O}$ embryo tested and is filtered through a 0.22 um filter.

sgRNA were designed with an online tool (http://crispr.mit.edu/). Details of the sequences are shown in Table 1 and Figure $34 \mathrm{~B}$.

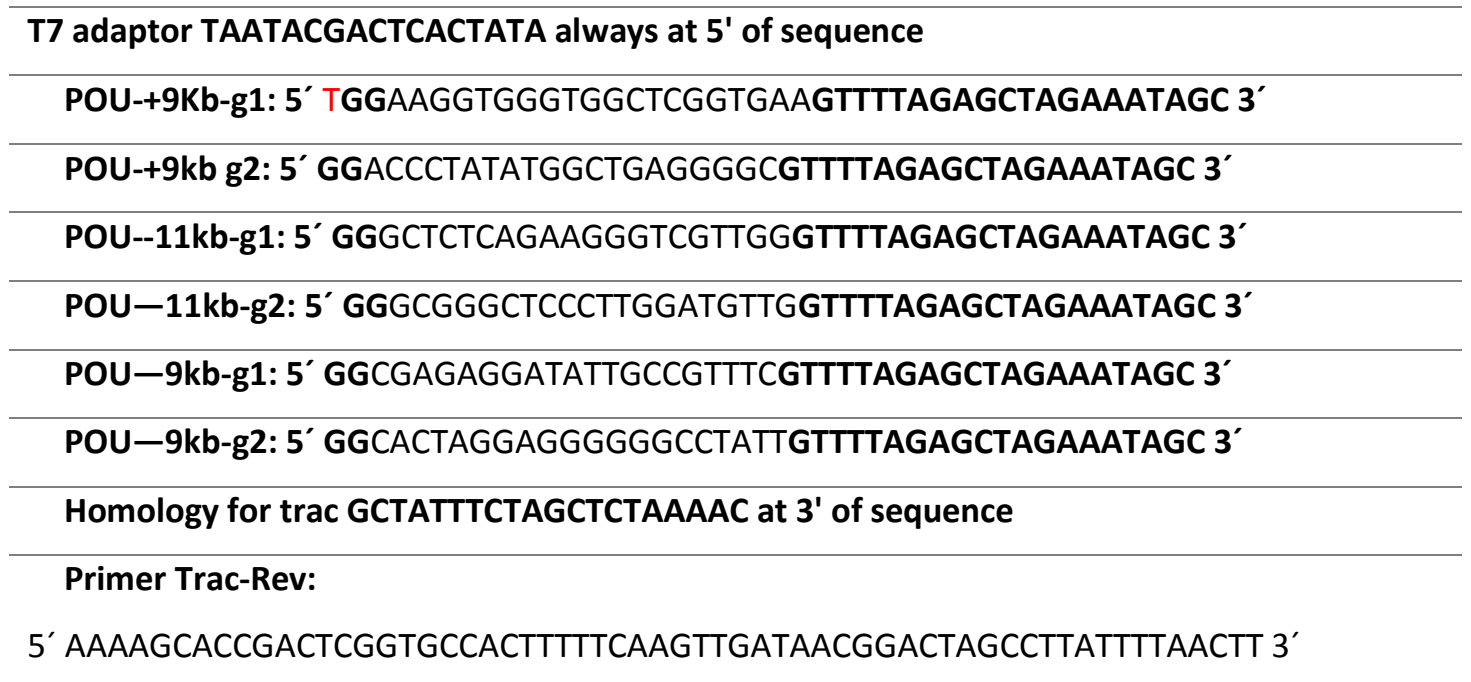

Table 1. List of sequences necessary to obtain the sgRNA+tracrRNA: T/ sequence was add to all the sgRNAs.

Primers for genotyping the deletions are detailed in table 2 :

\begin{tabular}{c}
\hline "Pou3f1 del-9kb Fw": 5'CtAGTATGCCCGGGTTtGTG 3' \\
\hline "Pou3f1 del-9kb Rv": 5' TCAATGGTCCTTCTGGCTCT 3' \\
\hline "Pou3f1 del-11kb Fw": 5' tCTCTCTCTCCCCCTGATGA 3' \\
\hline "Pou3f1 del-11kb Rv": 5' AAGCCTCCACGACAGAAGAA 3' \\
\hline "Pou3f1 del +9kb Fw": 5' AACCAGCCTCAGACATTTGG 3' \\
\hline "Pou3f1 del +9kb Rv": 5' tCCAGCACTTGGACTCACAC 3'
\end{tabular}

The product of the PCR was run on an agarose gel, the specific band was excised and DNA was extracted with the DNA extraction kit (Qiagen). Purified DNA was transcribed for RNA collection/isolation. 
After injection, embryos were cultured in M16 (Sigma) covered with mineral oil (Nid Oil, EVB) up to the two cell stage. Living embryos were then transfered into a pseudopregnant CD1 female, previously crossed with a vasectomized male.

E6.5 embryos were recovered for transient experiments. For the generation of a stable line we let the embryos be born. $+9 \mathrm{~Kb}$ Pou3f1 deletion line is maintained in an outbred background (CD1). Control mice for the line experiments are embryos from $\mathrm{F} 1$ males crossed with CD1 females.

\section{Culturing embryos at the onset of gastrulation}

We recovered the embryos at E6.25 and cultured them for 8 hours up to primitive streak (PS) stage (Downs and Davies, 1993). Culture medium has been already described (Glanville-Jones et al., 2013), it contains half rat serum and half a N2B27 based medium. Embryos were cultured in pools, as close contact among them was shown to improve growth. As rolling culture did not represent any improvement in the embryo morphology we culture them in four-well plates at $37^{\circ} \mathrm{C}$ and $5 \% \mathrm{CO}_{2}$.

\section{Chimera generation}

Chimeras were generated by the transgenic unit at CNIC. Control and Nanog ${ }^{/-}$ ESC were injected/delivered in 8 cell stage embryos as previously described (Nagy et al., 2014). After transferring the embryos into pseudopregnant females, embryos were collected at E10.5.

\section{RT-qPCR assays}

RNA was isolated from ESCs, using the RNeasy Mini Kit (Qiagen) and reverse transcribed using the High Capacity cDNA Reverse Transcription Kit (Applied Biosystems). RNA from individual E6.5-7.5 embryos, sorted E9.5 or sorted bone marrow populations was isolated using the Arcturus PicoPure RNA Isolation Kit (Applied Biosystems) and reverse transcribed using the Quantitect Kit (Qiagen). 
cDNA was used for quantitative-PCR (qPCR) with Power SYBR® Green (Applied Biosystems) in a 7900HT Fast Real-Time PCR System (Applied Biosystems). Expression of each gene was normalized to the expression of the housekeeping genes Actin and Ywhaz (Table 3).

\begin{tabular}{|c|c|c|}
\hline & Forward Primer & Reverse Primer \\
\hline Nanog & CTTACAAGGGTCTGCTACTGAGATGC & TGCTTCCTGGCAAGGACCTT \\
\hline Brachyury & GTCTAGCCTCGGAGTGCCT & CCATTGCTCACAGACCAGAG \\
\hline Eomes & TTCACCTTCTAGAGACACAG & GAGTTAACCTGTCATTTTCTG \\
\hline$K d r$ & TTTGGCAAATACAACCCTTCAGA & GCAGAAGATACTGTCACCACC \\
\hline Runx1 & GCAGGCAACGATGAAAACTAC & GCAACTTGTGGCGGATTTGTA \\
\hline Tal1 & CACTAGGCAGTGGGTTCTTTG & GGTGTGAGGACCATCAGAAATCT \\
\hline Gata1 & CTGCATCGCTCCCTGTCAC & GCAGGCTTCCATGAAACTTGG \\
\hline KIf1 & AGACTGTCTTACCCTCCATCA & GGTCCTCCGATTTCAGACTCA \\
\hline$H b b-b h 1$ & GAAACCCCCGGATTAGAGCC & GAGCAAAGGTCTCCTTGAGGT \\
\hline Stil & GACACAATTCAGGACTGGTAGAC & GGATGATCCACTTTCTGTTCA \\
\hline Ywhaz & CGTTGTAGGAGCCCGTAGGTCAT & TCTGGTTGCGAAGCATTGGG \\
\hline Actin $b$ & CAGAAGGAGATTACTGCTCTGGCT & TACTCCTGCTTGCTGATCCACATC \\
\hline
\end{tabular}

Table 3. Primer sequences for RTqPCRs

\section{Flow cytometry}

E9.5 and E10.5 embryos were disaggregated with $0.25 \%$ collagenase type I (Stemcell Technologies) at $37^{\circ} \mathrm{C}$ for $30 \mathrm{~min}$, and the cells were washed with PBS containing $2 \% F B S$ (Gibco) and filtered through a $70 \mu \mathrm{m}$ mesh. The single cell suspension was then incubated for $30 \mathrm{~min}$ at $4^{\circ} \mathrm{C}$ with the following antibodies: antiCD71-FITC (BD Biosciences, 1:100), antiTer119-APC (BD Biosciences, 1:100), anticKit-PEcy7 (BD Biosciences, 1:100), and antiCD41-PE (BD Biosciences, 1:100). Samples were analyzed with the BD LSRFortessa flow cytometer.

Bone marrow of adult mice was obtained from femurs and tibias crushed in a mortar and filtered through a $70 \mu \mathrm{m}$ mesh to obtain single-cell suspensions. For hematopoietic cell maturation assays, a small fraction of the bone marrow was separated and the rest was depleted of red blood cells by lysis in FACSLysing solution (BD Biosciences). Antibodies used for blood maturation assay were 
antiCD71-FITC (BD Biosciences, 1:100) and antiTer119-APC (BD Biosciences, 1:100). Antibodies for BM precursor sorting were Biotinylated lineage cocktail (BD Biosciences, 1:50), antiCD34 (RAM34)-FITC (BD Biosciences, 1:100 30min at RT), anticKit-PEcy7 (BD Biosciences, 1:100), antiCD16/32-BV605 (BD Biosciences, 1:100), and antiSca1-PerCP-Cy5.5 (BD Biosciences, 1:100).

\subsection{Transplant assays}

C57BI6 CD45.1+ mice of 15 weeks old were treated with cefovecin to avoid infections and the next day irradiated in an irradiator with 5.5 grays and 3 hours later with another 5.5 grays. The same day were injected with 1.500 .000 bone marrow cells CD45.2+ from Nanogtg mice. Bone marrow was depleted of erythrocytes with sterile FACSLysing solution (BD Biosciences). All the process was performed in sterile conditions.

\subsection{Methocult and cytospin}

1000 cells of sorted populations and total BM were plated in methyl cellulose (Methocult GF M3434, Stemcell technologies). After counting and assessing the different types of colonies, to verify the type of colonies, we recover them from the plate and cytospin them to observe cell morphology, centrifuging the samples directly into microscope slides. Staining was done with hematoxylin and eosin.

\section{Cell culture}

ESCs were maintained in serum-free conditions with Knock out serum replacement (Thermofisher), LIF (produced in-house), and 2i (CHIR-99021, Selleckchem; and PD0325901, Axon) and over mouse embryonic fibroblast (MEFs). The ESCs used were BT12 (NanogKO) and E14Tg2a (its parental wt cell line), kindly provided by lan Chambers and Austin Smith (Chambers et al., 2007). Gain of function ES cells (NOES) were derived in the lab from Nanogtg mice and karyotyping of the obtained lines was performed by the pluripotent cell technology unit at CNIC (Nagy et al., 2014).

\subsection{Hematopoietic differentiation}

ESC were differentiated toward hematopoieisis according to modified protocols (Irion et al., 2010, Lesinski et al., 2012, Sroczynska et al., 2009). For embryoid 
body formation, 5000 ESCs were plated in StemPro34 medium supplemented with nutrient supplement (Gibco) and $2 \mathrm{mM}$ I-glutamine (I-Gln), penicillin/streptomycin (Gibco), $50 \mu \mathrm{g} / \mathrm{ml}$ ascorbic acid, $200 \mu \mathrm{g} / \mathrm{ml}$ iron saturated transferrin, $4 \mathrm{ng} / \mathrm{ml}$ recombinant human BMP4, and $4 \times 10^{-4}$ monothioglycerol. After 2.5 days, the cultures were supplemented with $5 \mathrm{ng} / \mathrm{ml}$ recombinant human fibroblast growth factor 2 (rhFGF2; basic fibroblast growth factor [bFGF]), $5 \mathrm{ng} / \mathrm{ml}$ recombinant human activin $A, 5 \mathrm{ng} / \mathrm{ml}$ recombinant human VEGF (rhVEGF), 20 $\mathrm{ng} / \mathrm{ml}$ recombinant murine thrombopoietin (TPO), and $100 \mathrm{ng} / \mathrm{ml}$ recombinant murine stem cell factor (rmSCF). Cytokines were obtained from R\&D Systems Inc. or Peprotech. EBs were dissociated at day 5, 6 and 7 by treatment with $0.05 \%$ trypsin-EDTA at $37^{\circ} \mathrm{C}$ for $2-5$ minutes.

Dissociated EBs at day 5 and 6 were plated in Methocult SF M3436 methylcellulose medium for quantification of primitive erythroid progenitor cells (BFU-E). Dissociated EBs at day 5, 6, and 7 were plated in Methocult GF M3434 methylcellulose medium for quantification of erythroid progenitor cells (CFU-E), granulocyte-macrophage progenitor cells (CFU-GM, CFU-G, CFU-M), and multipotential granulocyte, erythroid, macrophage, and megakaryocyte progenitor cells (CFU-GEMM). Cells were plated in triplicate on ultra-low attachment surface plates (Corning) at 50,000 cells per plate. Plates were incubated in high humidity chambers for 12 days at $37^{\circ} \mathrm{C}$ and $5 \% \mathrm{CO}_{2}$. Whole plates were counted. For qPCR, EBs were directly lysed in extraction buffer and frozen at $-80^{\circ} \mathrm{C}$.

\subsection{Anterior neural differentiation}

NOES cells were differentiated to forebrain lineage as described (Gouti et al., 2014,2017 ) in monolayer using corning p24 plates with cell bind surface and with $0.1 \%$ gelatin (Sigma) added 30 min before passing. Cells were grown in N2B27

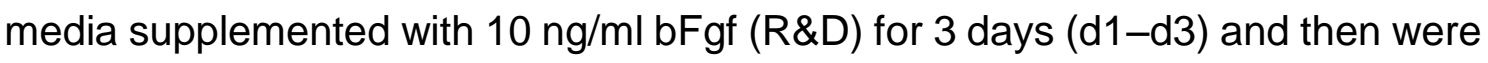
transferred to supplemented N2B27.

\subsection{Naïve to primed pluripotency differentiation}

NanogKO and control ES cells were maintained in serum-free conditions with Knock out serum replacement (KOSR,Thermofisher), LIF (produced in-house), and 2i (CHIR-99021, Selleckchem; and PD0325901, Axon) for two passes. When cells were growing at the same rate, they were resuspended and plated in 
adherent culture plates coated with gelatin $0.1 \%$ at a density of $7 \times 10^{4} \mathrm{cells} / \mathrm{cm}^{2}$ (Heo et al., 2005) on the same naïve media. $12 \mathrm{~h}$ after plating, media was removed and cells were washed with PBS $\times 2$. Differentiating media was added: DMEM (Invitrogen) with 20\%FBS (Hyclone), $2 \mathrm{mM}$ glutamine (Biosurce), 100U/ml penicillin/streptomycin (Biosource) and Bmercaptoethanol (Sigma) 1:1000. Cells were recover at $0 \mathrm{~h}, 12 \mathrm{~h}$ and $24 \mathrm{~h}$, considering 0 as $12 \mathrm{~h}$ after the cells have been replated in naïve conditions. RNA was extracted by adding RLT buffer (Qiagen) directly into the well.

\section{In situ hybridization}

Embryos were collected in cold PBS, transferred to 4\% PFA, and fixed overnight at $4^{\circ} \mathrm{C}$. After washing, embryos were dehydrated through increasing concentrations of PBS-diluted methanol (25\%, 50\%, 75\%, and 2X 100\%). In situ hybridization in whole mount embryos was performed as described (Acloque et al., 2008, Ariza-McNaughton \& Krumlauf, 2002). For embryos up to 8.5 we used nested wells to facilitate the process.

Signal was developed with anti-dioxigenin-AP (Roche) and BM-Purple (Roche). Images were acquired with a Leica MZ-12 dissecting microscope. Probes were obtained by PCR of cDNA with the following primers (Table 4):

\begin{tabular}{lll}
\hline & PrimerF & PrimerR \\
\hline Gata1 & ATTTAGGTGACACTATAGAA & GTAATACGACTCACTATAGGG \\
& GATGGAATCCAGACGAGGAA & CACTCAGGAACTGAGGCACA \\
\hline Klf1 & ATTTAGGTGACACTATAGAA & GTAATACGACTCACTATAGGG \\
& CCACAGTACCAAGGCCACTT & ATCTCACCCCAGTCCATCTG \\
\hline Hbb-bh1 & ATTTAGGTGACACTATAGAA & GTAATACGACTCACTATAGGG \\
& ACTCTGGGAAGGCTCCTGAT & TTGTGCTCTCAATGCAGTCC \\
\hline Redrum & ATTTAGGTGACACTATAGAA & GTAATACGACTCACTATAGGG \\
& GTTGCACTGCAGGTTCTTCA & TTCCCGCTATGTGAGTTCC \\
\hline Sox2 & ATTTAGGTGACACTATAGAA & GTAATACGACTCACTATAGGG \\
& ATGGGCTCTGTGGTCAAGTC & TGGACATTTGATTGCCATGT \\
\hline Pou3f1 & ATTTAGGTGACACTATAGAA & GTAATACGACTCACTATAGGG \\
& CCTGGGGTCCTTCTAACTCC & TTCGGTTTAGTCGGGCATAC
\end{tabular}

Table 4. Primer sequences for probe preparation for ISH. 


\section{RNAseq analysis}

\subsection{Nanog ${ }^{K O}$ ES cell RNAseq}

RNA from NanogKO ES cells and their parental line was extracted as indicated before. Next generation sequencing single read (Illumina HiSeq 2500) and library preparation (New England Biolabs Nest Ultra RNA library prep Kit) was performed in the genomic unit at CNIC.

Sequencing reads were inspected by means of a pipeline that used FastQC (http://www.bioinformatics.babraham.ac.uk/projects/fastqc) to asses read quality, and Cutadapt v1.3 (Martin, 2011) to trim sequencing reads, eliminating Illumina adaptor remains, and to discard reads that were shorter than $30 \mathrm{bp}$. For libraries amplified with the NuGen Ovation Single Cell kit, the first 8 nucleotides of each read were also eliminated with fastx_trimmer (http://hannonlab.cshl.edu/fastx). The resulting reads were mapped against the mouse transcriptome (GRCm38 assembly, Ensembl release 76) and quantified using RSEM v1.2.20 ( $\mathrm{Li}$ and Dewey, 2011). Raw expression counts were then processed with an analysis pipeline that used Bioconductor packages EdgeR (Robinson et al., 2010) for normalization (using TMM method) and differential expression testing, and ComBat (Johnson et al., 2007) for batch correction. Only genes expressed at a minimal level of 1 count per million, in at least 3 samples, were considered for differential expression analysis. Changes in gene expression were considered significant if their Benjamini and Hochberg adjusted p-value (FDR) was lower than 0.05 .

\subsection{Analysis of gene set in $\operatorname{Nanog}^{K O}$ versus control}

To obtain the set of genes that are upregulated in Nanog ${ }^{K O}$ or in control along time, we look into genes that had no differences at Oh between wt and Nanog KO, and that had increase expression for either Nanog ${ }^{K O}$ or wt at $24 \mathrm{~h}$. For that we used this conditions to filter them in R program.

For increased expression in KO ES cells

\# No great difference at Oh between WT and KO, CPM based abs(data\$ave_E14_0h - data\$ave_BT12_0h) <

$0.6^{\star}$ pmax(data\$ave_E14_0h,data\$ave_BT12_0h)

\# Increased expression with time for the $\mathrm{KO}$

\& data\$BT12_0h_vs_BT12_12h_logFC $<0$ 
\& data\$BT12_12h_vs_BT12_24h_logFC $<0$

$\&$ data\$BT12_0h_vs_BT12_24h_logFC <- $\log 2(3)$

\# Significant negative difference at $24 \mathrm{~h}$ between WT and KO, CPM based

$\&-1$ * (data\$ave_E14_24h - data\$ave_BT12_24h) $>3$ *

abs(data\$ave_E14_0h - data\$ave_BT12_0h)

\& data\$E14_24h_vs_BT12_24h_logFC $<0$

\& data\$E14_24h_vs_BT12_24h_adj.P.Val $<0.05$

For increased expression in control ES cells

\# No great difference at Oh between WT and KO, CPM based

abs(data\$ave_E14_0h - data\$ave_BT12_0h) <

$0.6^{*}$ pmax (data\$ave_E14_0h,data\$ave_BT12_0h)

\# Increased expression with time for the WT

\& data\$E14_Oh_vs_E14_12h_logFC $<0$

\& data\$E14 12h vs E14 24h $\operatorname{logFC}<0$

\& data\$E14_0h_vs_E14_24h_logFC <-log2(3)

\# Significant positive difference at 24h between WT and KO, CPM based

$\&\left(\right.$ data $\$ a v e \_E 14 \_24 \mathrm{~h}$ - data\$ave_BT12_24h) $>3 *$ abs(data\$ave_E14_0h data\$ave_BT12_0h)

\& data\$E14_24h_vs_BT12_24h_logFC $>0$

$\&$ data\$E14_24h_vs_BT12_24h_adj.P.Val $<0.05$

Both set of genes are filtered for adjusted Pvalue in the comparison between Control 24h Vs Nanog ${ }^{K O} 24 \mathrm{~h}$

\subsection{Analysis of scRNAseq of E6.5}

Two different data sets from different experiments (Mohammed et al., 2017a; Scialdone et al., 2016) were normalized by quantiles and batch corrected. To plot the cells in a tSNE genes with variance $=0$ were eliminated.

For correlation of genes with Nanog we used the slope of the line and how it adjusts to the points. For mutual exclusion in nascent mesoderm of the flk $1+$ cells (Scialdone et al., 2016) we use a hypergeometric test. In both cases for ploting we used ggPlot package from $\mathrm{R}$, where we also perfomed statistics.

\subsection{Intersection analysis}

The intersection analysis of the genes coming from different RNAseq datasets was performed in the web tool from Bioinformatics and Evolutionary Genomics (http://bioinformatics.psb.ugent.be/webtools/Venn/) 

RESULTS 



\section{RESULTS}

\section{Embryonic defects induced by Nanog in the E9.5 mouse}

\subsection{A mouse model for controlled Nanog gain-of-function}

Nanog loss of function leads to embryonic lethality at preimplantation stages (Mitsui et al., 2003a), therefore preventing the analysis of its putative role at later stages of development when it is re-expressed at the posterior part of the gastrulating mouse embryo (Hart et al., 2004b). To overcome this obstacle, we used an inducible TetON transgenic model (Nanog ${ }^{\text {tg) }}$ in which Nanog expression is induced by the administration of doxycycline (dox) (Piazzolla et al., 2014). It consist in a double transgenic line comprising:

1. M2-rTA transactivator under the Rosa26 promoter, and therefore expressed throughout the whole embryo (not extraembryonic tissues). In the presence of doxycycline is able to bind a Tet-operator (Tet-OP)

2. TetOP that upon binding of the M2-rTA activates the expression of Nanog cDNA. It is inserted in the Col1a1 locus.

Consequently, with this double transgenic line we can regulate Nanog expression temporarily by the administration of doxycycline (dox) (Fig 10).

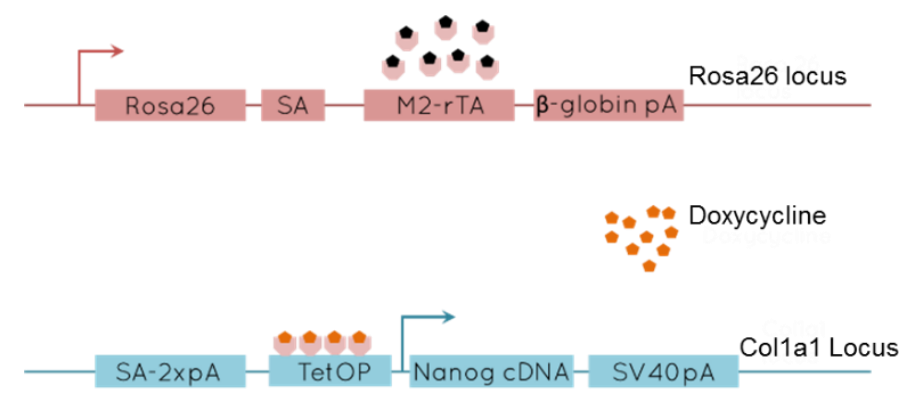

Figure 10. Nanog ${ }^{\text {tg }}$ TetON system: Schematic representation of both loci necessary for the expression of Nanog. In pink the Rosa26 locus, that expresses the transactivator. In blue the tetracycline operator, if bound by the transactivator together with the doxycycline (in orange) it is able to express Nanog cDNA.

\subsection{Nanog induces loss of blood and neural defects in the embryo}

We induced Nanog from E6.5 in order to prolong its expression beyond E7.5, when it is normally turned off (Hart et al., 2004b), and examined the embryos at E9.5. Since we were ectopically expressing a pluripotency factor we could have found a general reversion of the embryonic tissues towards a pluripotent stage. However, based on previous works where overexpressing Sox2 or Oct4 leads to 
a directed differentiation towards specific tissues (Niwa et al., 2000; Wang et al., 2012), we were also expecting more limited effects.

Actually, when we recovered the Nanogtg embryos at E9.5 after treating them with doxycycline we observed a much delimited and specific phenotype: Embryos had anterior neural defects and a complete lack of blood (Fig 11). Since apparently Nanog was not affecting any other lineage or tissue, we wondered what could be the reason for these phenotypes and how could that relate with the physiological role of Nanog given its pattern of expression during gastrulation.

On one hand, red blood cells (RBC) are the first mesodermal cells to migrate through the primitive streak and they are already primed in the epiblast at the time Nanog is still expressed. Also, these primitive erythroid cells are conforming the majority of circulating blood cells in the E9.5 embryo.

E9.5 Nanog ${ }^{\text {tg }}-$ dox

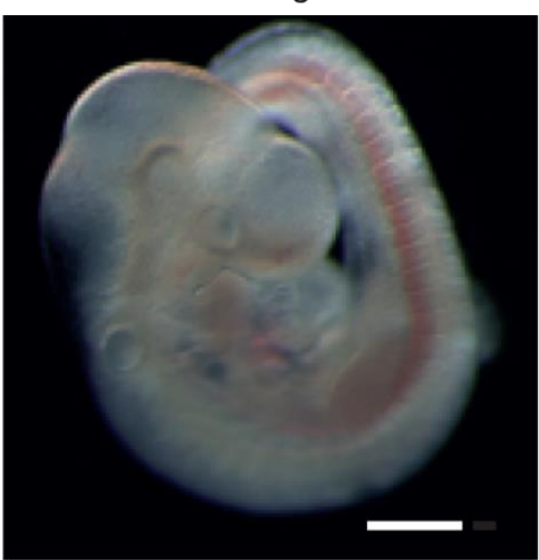

E9.5 Nanogtg + dox

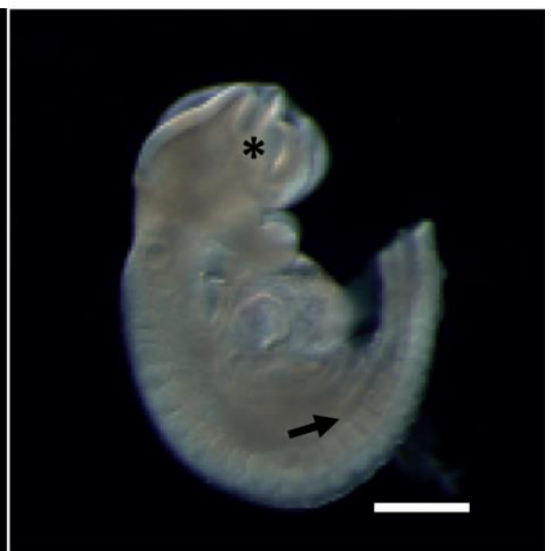

Figure 11. Phenotype of Nanog $^{\text {tg }}$ embryos at E9.5 after treatment with doxycycline for three days: Representatives embryo without (-dox) and with (+dox) treatment. Asterisk marks craniofacial defects and arrow points out the lack of blood. Scale bar, 750um.

On the other hand, since Nanog is one of the earliest genes to show restricted expression in the posterior epiblast, it could have a role not only promoting gastrulation (Hoffman et al., 2013a; Tarafdar et al., 2013) but also repressing anterior fate.

These observations suggested that Nanog could be playing very specific roles at the onset of gastrulation, by maintaining hematopoietic and anterior neural determination on hold. Exploring the putative mechanism by which Nanog exerts these actions has been the aim of this work. 


\section{A role for Nanog in primitive hematopoiesis}

\subsection{Nanog blocks erythropoiesis in developing mouse embryos}

To confirm the observation of the lack of blood we carried out whole mount in situ hybridization for Hbb-bh1 (Wilkinson et al., 1987), encoding the beta-like embryonic hemoglobin, and for Redrum, an erythroid-specific long non-coding RNA (Alvarez-Dominguez et al., 2014; Paralkar et al., 2014). At E9.5, Hbb-bh1 labels primitive red blood cells that are distributed throughout the yolk sac. Expression of Nanog up to this stage results in a nearly complete block of $\mathrm{Hbb}$ bh1 expression (Fig 12). Redrum expression is observed in the developing aortagonad-mesonephros (AGM) region and in the tail bud of the embryo. Again, induction of Nanog leads to loss of Redrum expression in the AGM, but interestingly not in the tail bud (Fig 12).

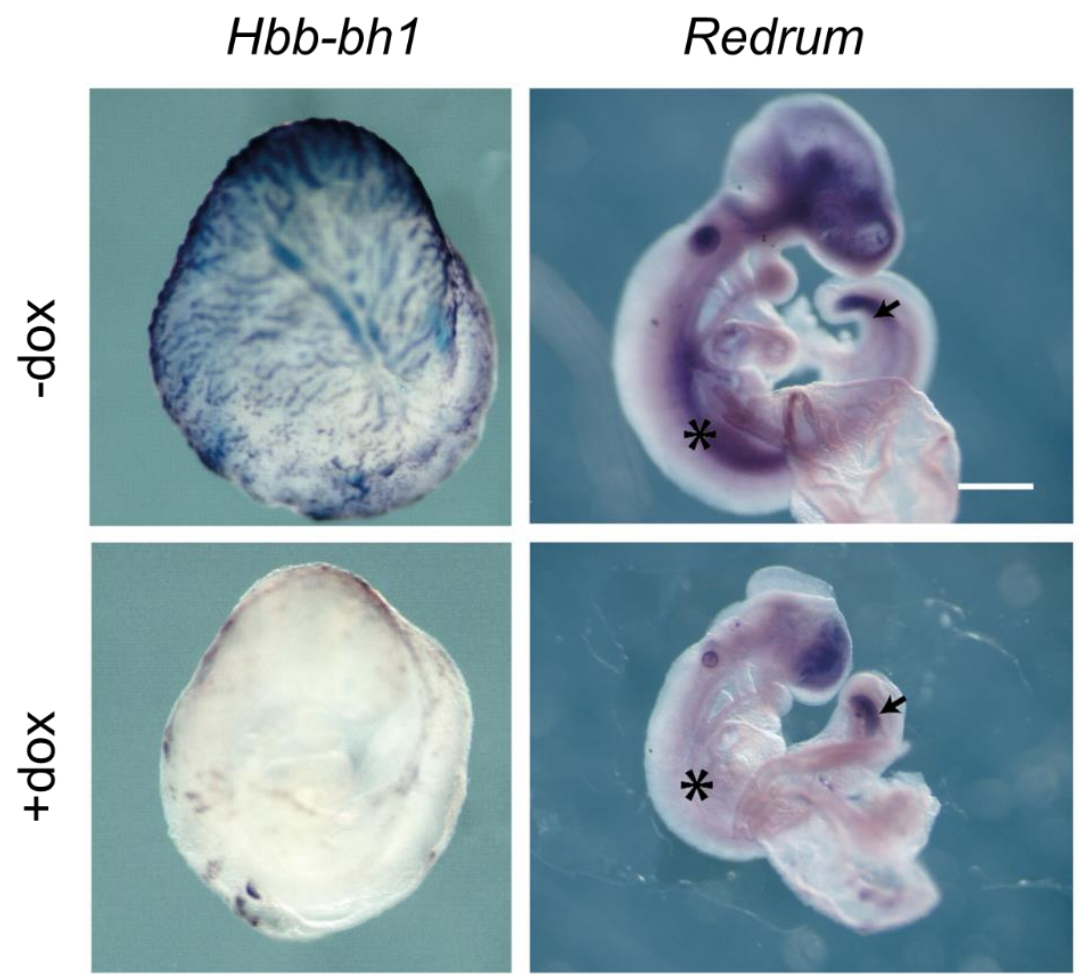

Figure 12. In situ hybridization of $\mathbf{H b b}$-bh 1 and Redrum: Effect in E9.5 embryos of sustained Nanog on the expression of Hbb-bh1 (left) and Redrum (right). Upper panels, controls not treated with doxycycline; lower panels, 3 days doxycycline treated embryos. The asterisk indicates expression of Redrum in the AGM, and the arrow in the posterior region. Scale bar, 750 um. 


\subsection{Nanog does not affect developing vessels}

In the early gastrulating embryo, cells from the epiblast that will give rise to RBC migrate through the primitive streak to the extraembryonic region, where they can give rise to either vessels or hematopoietic cells (Padrón-Barthe et al., 2014). Therefore we checked if the apparent lack of blood was accompanied by vasculature defects. Immunostaining for Endomucin, a marker for endothelial cells expressed in embryonic endothelial cells, revealed no substantial differences at E9.5 between dox-treated and untreated Nanog ${ }^{\text {tg }}$ embryos, as is observed in the correct patterning of intersomitic vessels (Fig 13).
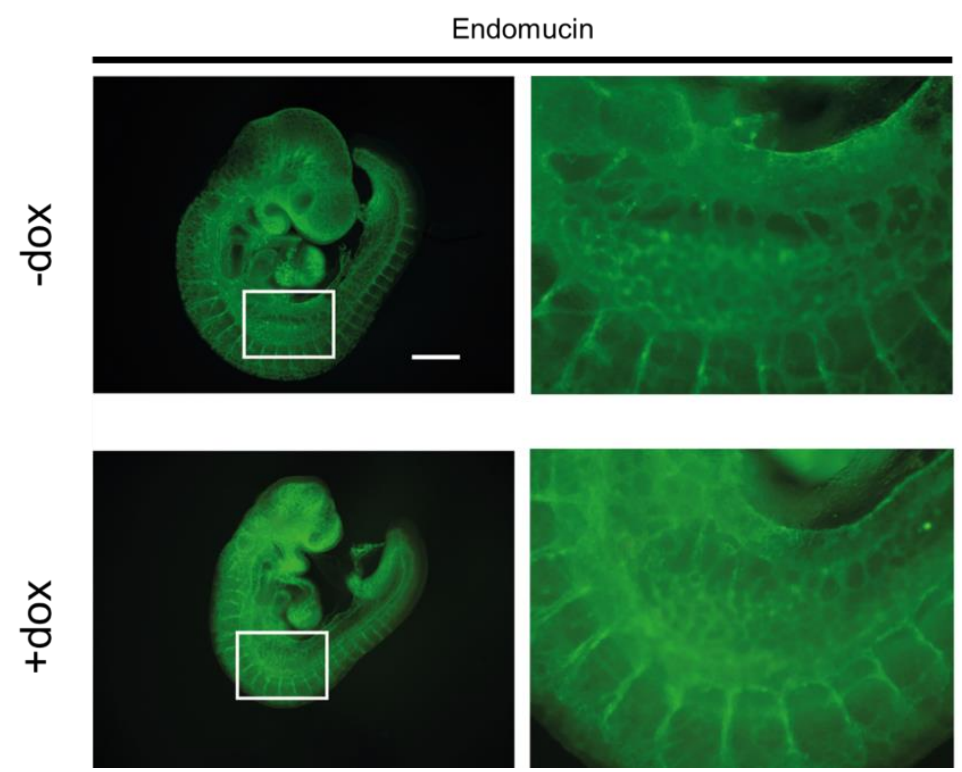

Figure 13. Endomucin staining of vessels of E9.5 Nanog ${ }^{\text {tg }}$ embryos: with (+dox) and without (-dox) treatment. Right panels show close-up view of the boxed areas on left panels. White box is zoomed in in the panel next to it. Scale bar 750um.

Prolonged Nanog expression in the embryo causes a deficit in primitive red blood cells that is accompanied by lack of expression of erythroid-specific genes, but does not affect early vascular development.

This anaemic phenotype was present in all stages of development. When we treated Nanog ${ }^{\text {tg }}$ embryos with dox from E10.5 to E14.5 we recovered embryos with a strong anaemic phenotype (Fig 14). 


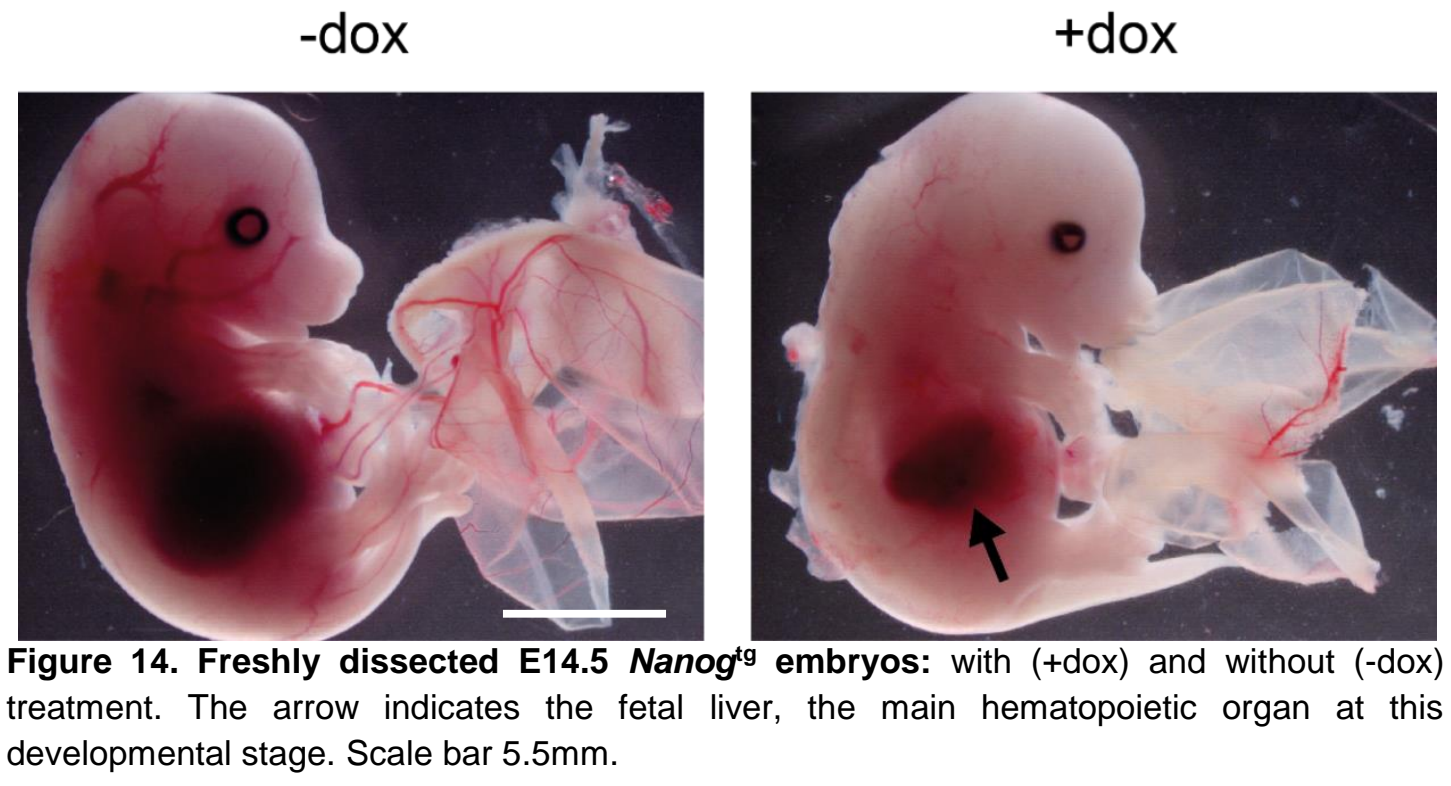

\subsection{Flow cytometry analysis reveals a specific effect of Nanog on erythroid} differentiation

To characterize the effect of Nanog induction on hematopoiesis, we separated progenitors and red blood cells by flow cytometry of dispersed yolk sacs of E9.5 embryos using c-Kit (a marker of early uncommitted progenitors), CD41 (hematopoietic progenitors) , CD71 (red blood cell precursors), Ter119 (matured red blood cells) (Baron et al., 2012; Tober et al., 2007). We found no differences in total cell number of uncommitted (c-Kit+) or committed hematopoietic progenitors (c-Kit+ CD41+) nor in megakaryocyte precursors (c-Kit- CD41+) (Fig $15 A, B)$. 

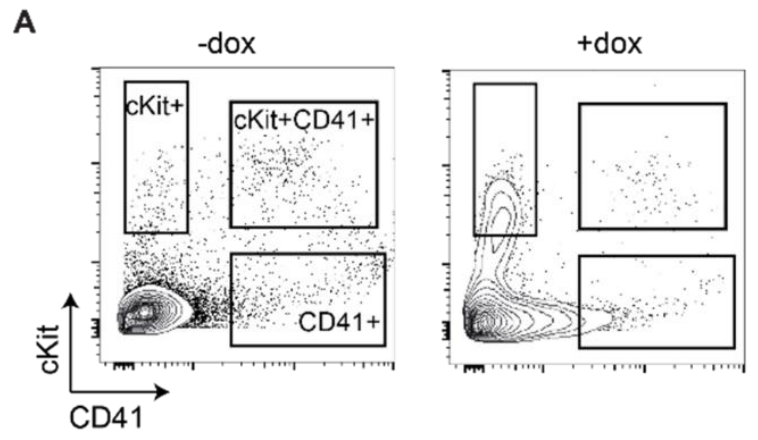

B

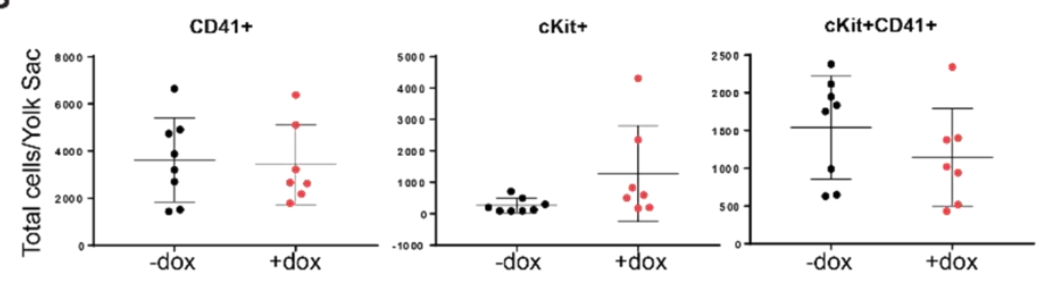

Figure 15. FACS analysis of E9.5 hematopoietic population: (A) Repesentative FACS images showing the distribution of cKit+CD41-, cKit+CD41+ ckit-CD41+ fractions in the E9.5 embryo. (B) Graphic representation of the cKit+CD41-, cKit+CD41+ ckit-CD41+ FACS dot plots. Each assay contained a pool of 10 E9.5 embryos per condition: 8 untreated (-dox) and 7 treated (+dox). All statistics were performed using Student's $t$ test.

We further characterized the erythroid phenotype by analyzing cell maturation by flow cytometry using CD71 and Ter119 (Borges et al., 2012). We observed an increase in the proportion of immature types (S0 and S1) together with a reduction in more mature erythroid cells (S2), suggesting a block in the differentiation of red blood cells (Fig 16A,B). Together, these results show that Nanog expression in the embryo leads to a specific deficiency of the erythroid lineage. 
A

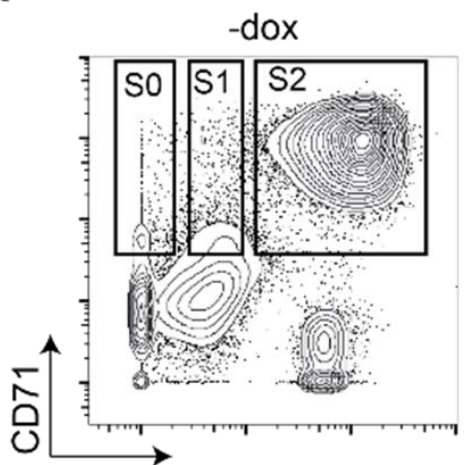

Ter119
B

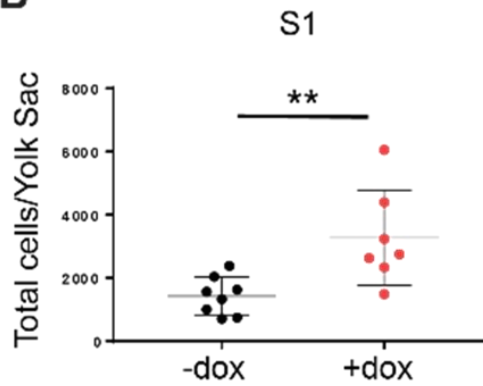

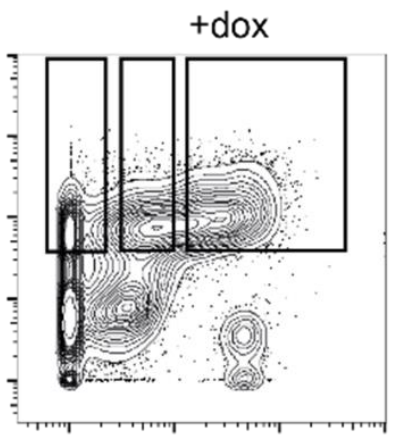

S2

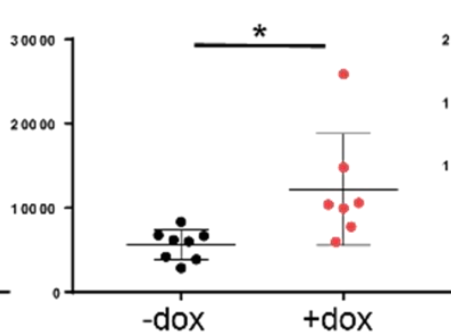

C

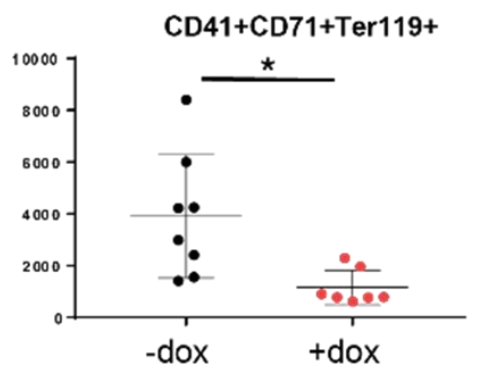

3

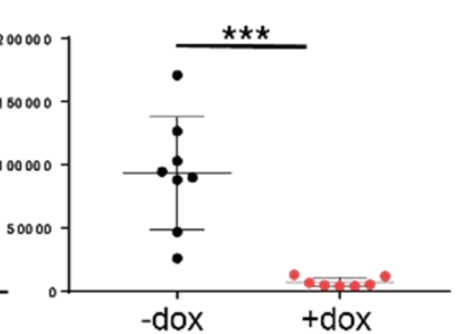

Figure 16. FACS analysis of E9.5 erythroid population: (A) Representative FACS images showing the distribution of the CD71+Ter119+population in E9.5 single Nanog tg embryos with and without doxycycline. S0: CD71+Ter119-, S1:CD71+Ter119low and S2:CD71+Ter119+ represent different state of progression of blood maturation. (B) Graphic representation of the Ter119 CD71 CD41+ FACS dot plots in untreated (-dox) and treated (+dox) embryos. $n=7^{* * *} \mathrm{P}<$ 0.00005, ${ }^{* *} \mathrm{P}<0.0005,{ }^{*} \mathrm{P}<0.005$. (C) Graphic representation of the Ter119 CD71+ FACS dot plots. $n=7{ }^{*} P<0.005$. All statistics were performed using Student's $t$ test.

\subsection{Nanog downregulates the expression of key erythroid determination genes in the embryo}

We next investigated how the extension of Nanog expression to E9.5 influences hematopoietic gene expression. For this, we isolated progenitor and mature populations by flow cytometry as described above (Fig 15A 16A), and conducted RT-qPCR to examine the expression of core lineage determinants of hematopoietic fate: Runx1, Tal1, Gata1, and Klf1 (Chen et al., 2009; Kuvardina et al., 2015; Palis et al., 1999; Yokomizo et al., 2008). Despite consistent gain of Nanog expression in all populations, we only found significant changes in gene expression in mature erythrocytes (S2: CD71+Ter119+ population) where we observe significant downregulation of Tal1 and an upregulation of Runx1, and in early hematopoietic progenitors (ckit+CD41-) in which we find Tal1 and Runx1 
downregulated, (Fig17). Expression of Gata1 is not affected in megakaryocyte precursors (CD41+), as is also the case for Runx1 (Fig 17). Taken together, these results suggest that Nanog causes a blockade in hematopoietic progenitors, preventing their differentiation towards erythroblast cells.

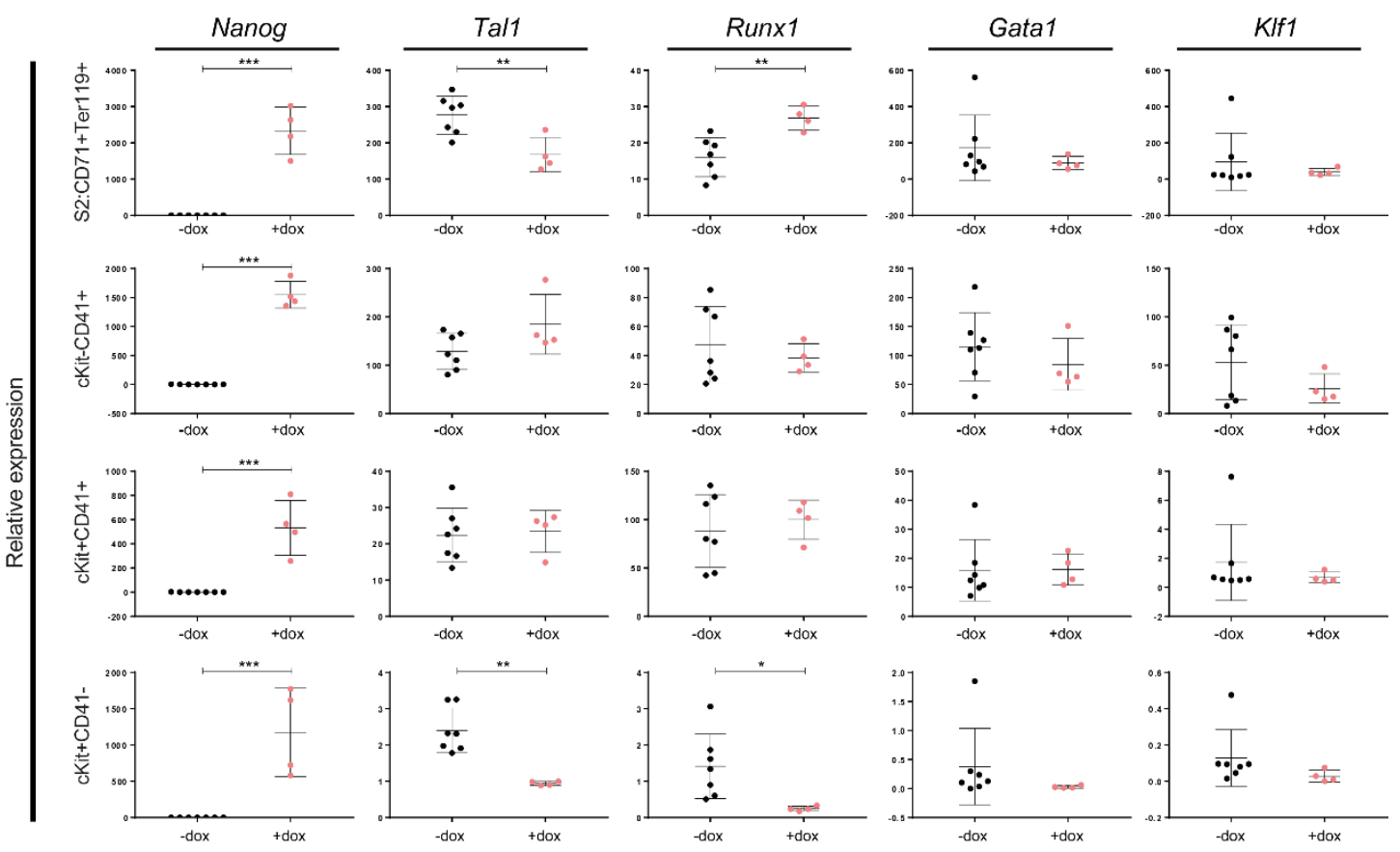

Figure 17. RT-qPCR of sorted hematopoietic populations: Differences in the expression levels of hematopoietic genes and Nanog between Nanog ${ }^{\top 9}$ with and without doxycycline of E9.5 embryos.-dox $n=7,+$ dox $n=4{ }^{* * *} P<0.0005,{ }^{* *} P<0.005,{ }^{*} P<0.05$. All statistics were performed with Student's t test.

To examine if red blood cell changes occur at earlier stages, we induced Nanog expression from E5.5 to E7.5, a time window spanning initiation of primitive hematopoiesis. Whole mount in situ hybridization showed decreased expression of Gata1 and Klf1 in the extraembryonic region, corresponding to the blood island domain (Fig 18). 


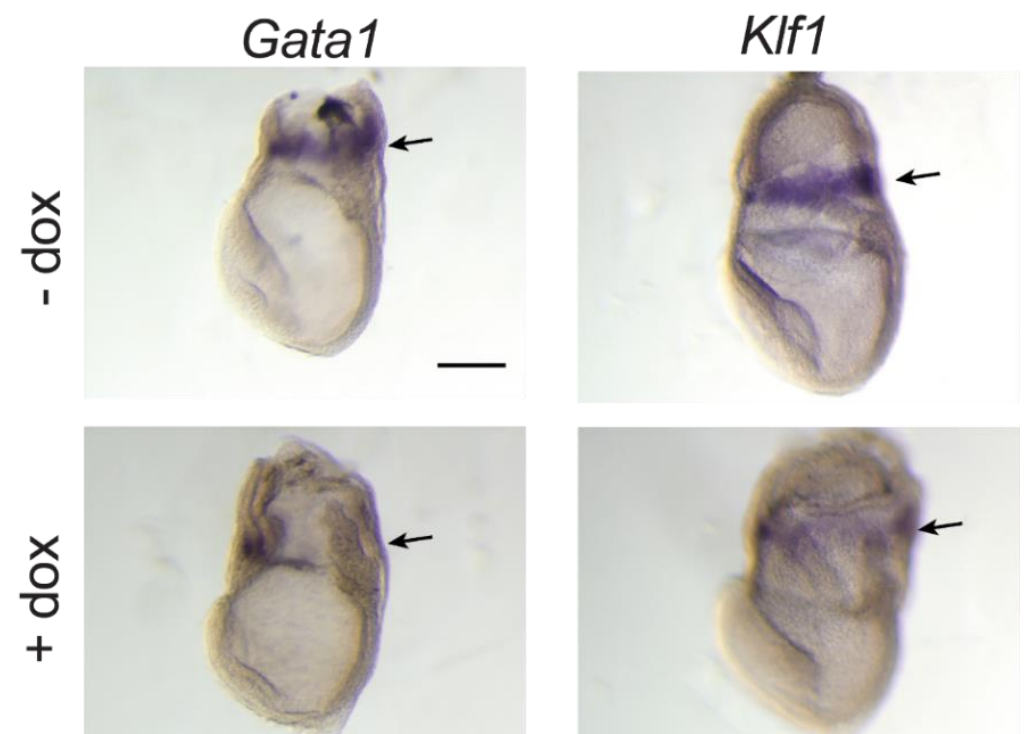

Figure 18. Whole mount in situ hybridization for Gata1 and KIf1: E7.5 Nanog ${ }^{\text {tg }}$ embryos without (-dox) and with (+dox) treatment with doxycycline. Arrows indicate the location of blood islands in the extraembryonic yolk sac. Scale bar, $750 \mu \mathrm{m}$.

RT-qPCR of individual dox-treated or control E7.5 Nanogtg embryos showed decreased expression of the core erythropoietic genes Tal1, Gata1, and Klf1 but no change in Runx1 (Fig 19). A possible explanation for our observations would be that Nanog expression causes a general blockade of mesodermal specification, with the downregulation of early hematopoiesis genes being merely a secondary effect of this. We therefore tested the expression of lineage determinants expressed at gastrulation (Brachyury and Eomes) and the early mesodermal gene Kdr (Palis et al., 1999; Shalaby et al., 1995). Exogenous Nanog induced the expression of both Brachyury and Eomes, in line with published data (Teo et al., 2011), but did not alter Kdr expression (Fig 19). 


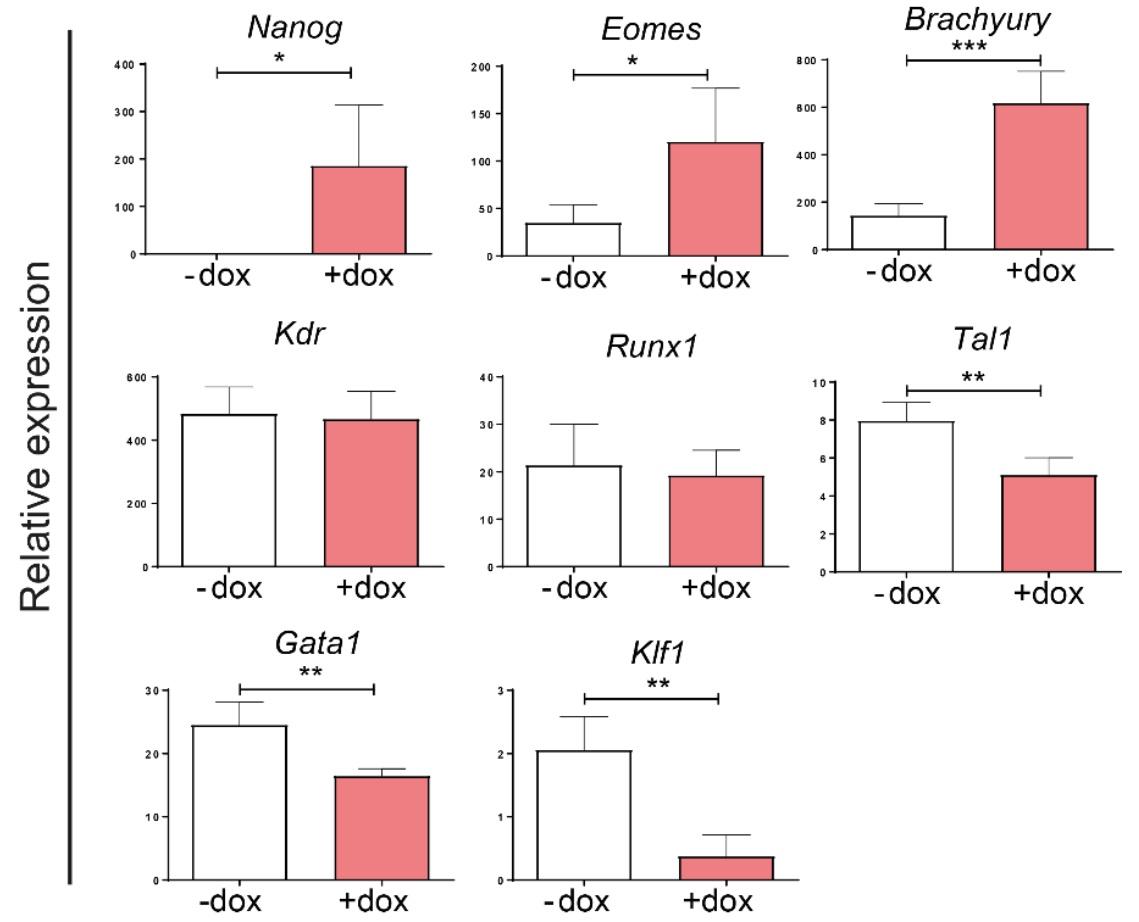

Figure 19 RT-qPCR of individual dox-treated or control E7.5 Nanog ${ }^{\text {tg }}$ : Relative expression of Nanog, mesodermal (Eomes, Brachyury, Kdr) and hematopoietic (Runx1, Tal1, Gata1, Klf1) genes in single control (-dox) or treated (+dox) E7.5 embryos ( $n=4$ per condition). Scale bar, $750 \mu \mathrm{m} .{ }^{*} P<0.05,{ }^{* \star} P<0.005,{ }^{* * *} P<0.0005$; All statistics were performed with Student $t$ test.

Together, these results suggest that Nanog blocks erythroid fate and is able to specifically downregulate the early expression of erythropoietic genes during the initial determination of primitive haematopoiesis, after mesodermal specification in the epiblast. 


\section{Is the effect of Nanog on erythroid lineage cell-autonomous?}

The results presented so far suggest that Nanog blocks specifically erythroid progenitors during primitive hematopoiesis. To test if this is the case, we aimed to rescue the observed genotype by generating chimeric embryos by injection of wild type ES cells constitutively expressing GFP (Díaz-Díaz et al., 2017) into Nanog ${ }^{\text {tg }}$ blastocysts.

A

B

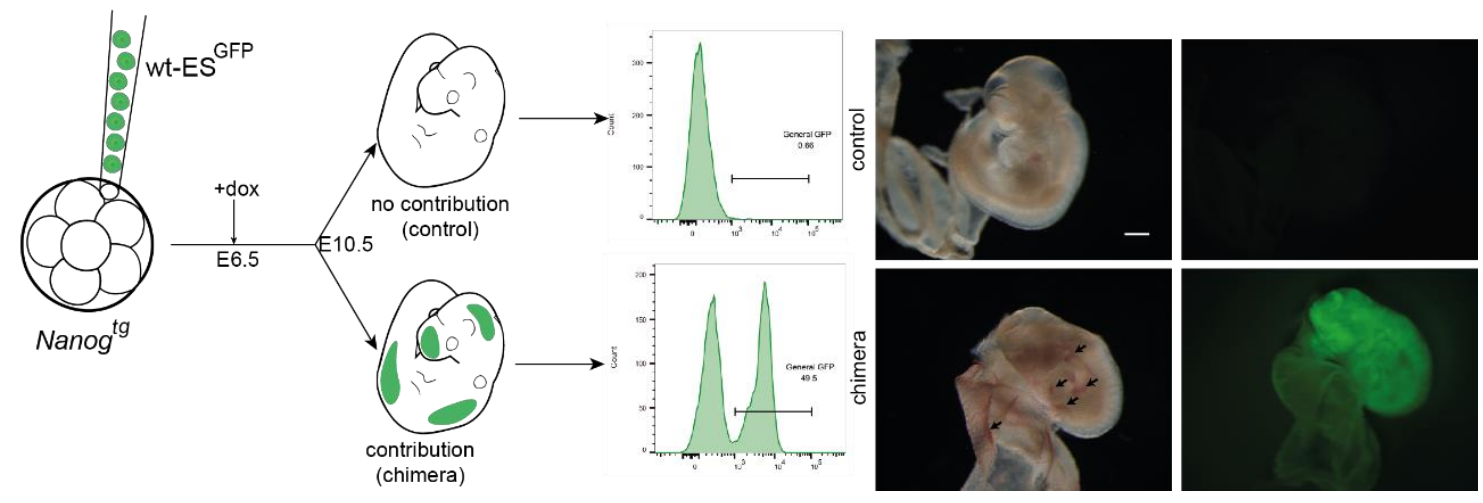

Figure 20. Wild type ES cells rescue erythroid maturation in chimeric embryos. (A) Experimental design for chimera generation and contribution of GFP cells to chimeric embryo (left hand side panels). (B) Freshly dissected dox-treated Nanogtg E10.5 embryos without (control) and with (chimera) contribution of wt-ESGFP cells (left, brightfield; right, GFP). Arrows mark the presence of blood in chimeric embryos that is absent from controls. Scale bar, 750 $\mu \mathrm{m}$.

The resulting embryos were treated in utero with dox at E6.5 and examined for GFP fluorescence at E10.5. Those showing no overall contribution (no GFP+ cells) were used as controls, whereas embryos containing GFP+ cells were considered chimeras (Figure $20 \mathrm{~A}, \mathrm{~B}$ ). Erythroid cells were evaluated in individual embryos by flow cytometry analysis of the S2 population (CD71+ Ter119+), as described earlier (Figure 16).

Chimeras with high contribution of wild type ES cells had circulating blood in both the embryo and the yolk sac, despite dox treatment, contrasting with embryos with no contribution (Fig 20). 
Chimeras showed a recovery of erythroid cells, with high contribution from GFP+ wild type ES-derived cells (Fig 21A). Quantification of erythroid populations in chimeras showed an increased content of CD71+ Ter119+ cells (Fig 21B); this increase did not occur when the experiment was repeated without dox treatment (Fig 21C). The number of GFP- cells (derived from Nanog expressing cells) in dox-treated chimeras did not differ from that in controls (with no contribution of GFP+ cells), demonstrating that the recovery of the erythroid populations in chimeras was entirely due to the wild type ES cells (Fig 21D). These results indicate that the effect of Nanog on erythroid progenitors is primarily cell autonomous, and not secondary to Nanog-induced changes in other cell types.

A

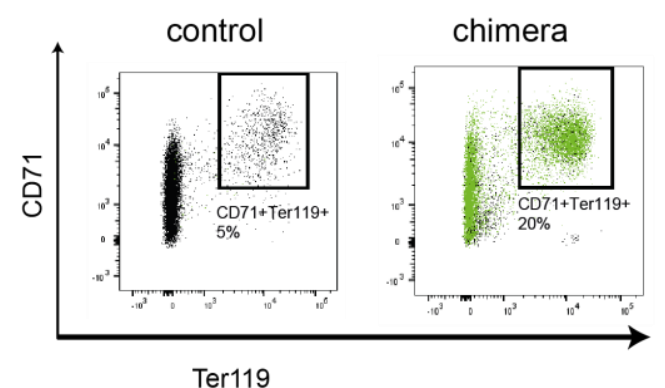

B

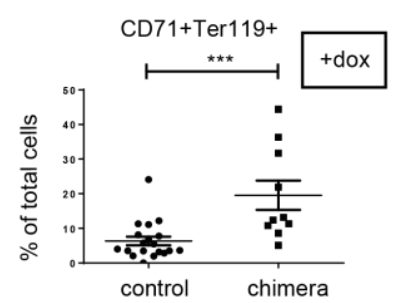

C

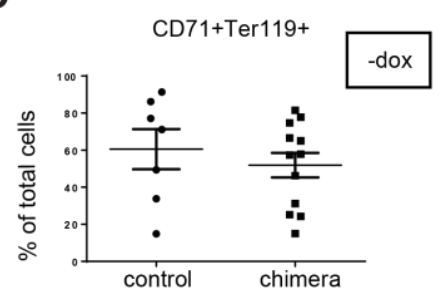

D

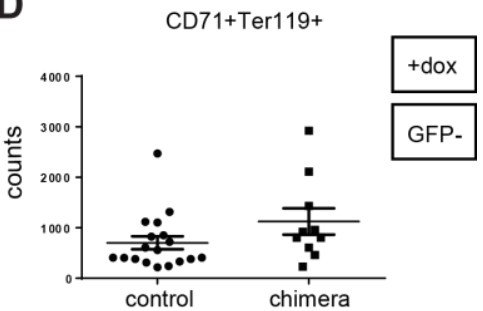

Figure 21. Wild type ES cells rescue erythroid maturation in chimeric embryos: $(A)$ Representative FACS plots showing of red blood cell maturation as determined by CD71/Ter119 staining in single dox-treated E10.5 control (left) and chimeric (right) embryos.(BD). Quantification of the CD71+ Ter119+ population in single dox-treated embryos (B; control, $\mathrm{n}=18$; chimera, $\mathrm{n}=10$ ), untreated embryos ( $\mathrm{C}$; control, $\mathrm{n}=7$; chimera, $\mathrm{n}=12$ ), and in GFP- cells (not derived from wild type ES cells) from dox-treated embryos ( $D$; control, $n=18$; chimera, $n=10) .{ }^{* *} P<0.0005$. All statistics were performed with Student's $t$ test. 


\section{Loss of Nanog enhances hematopoietic differentiation of ES cells}

\subsection{Colony forming units assay reveals increased potential for erythroid differentiation in Nanog $^{-/}$ES cells}

To investigate the effect of the absence of Nanog on the erythroid lineage, we tested the potential of ES cells with homozygous Nanog loss of function (Chambers et al., 2007b) to differentiate into blood cells in culture (Irion et al., 2010). Nanog-/ and wild type control ES cells of the parental strain (E14Tg2a) were used to generate embryoid bodies (EB). EBs were allowed to differentiate for up to 7 days in hematopoietic differentiation media. After disaggregation and culture different colony forming units (CFU) were scored between days 5 and 7 (D5-D7; Fig 22). Despite a trend for a decrease in the number of common myeloid progenitors (CFU-GEMM), Nanog-/ EBs generated significantly more primitive erythroid colonies (Ery-P) than controls, as well as a significantly higher number of mature erythroid colonies (BFU-E; burst forming unit erythroid) in the presence of cytokines driving a broader hematopoietic differentiation. Interestingly, there was no between-genotype difference in granulocyte-monocyte (CFU-GM) progenitors, but monocyte (CFU-M) or granulocyte (CFU-G) progenitors were produced more abundantly from wild type than from Nanog-/- EBs (Fig 22). This last observation is possibly the result of the decrease in common myeloid progenitors together with the significant increase of erythroid progenitors. Nanog 1- ES cells thus have an increased potential for specific differentiation to red blood cells. 

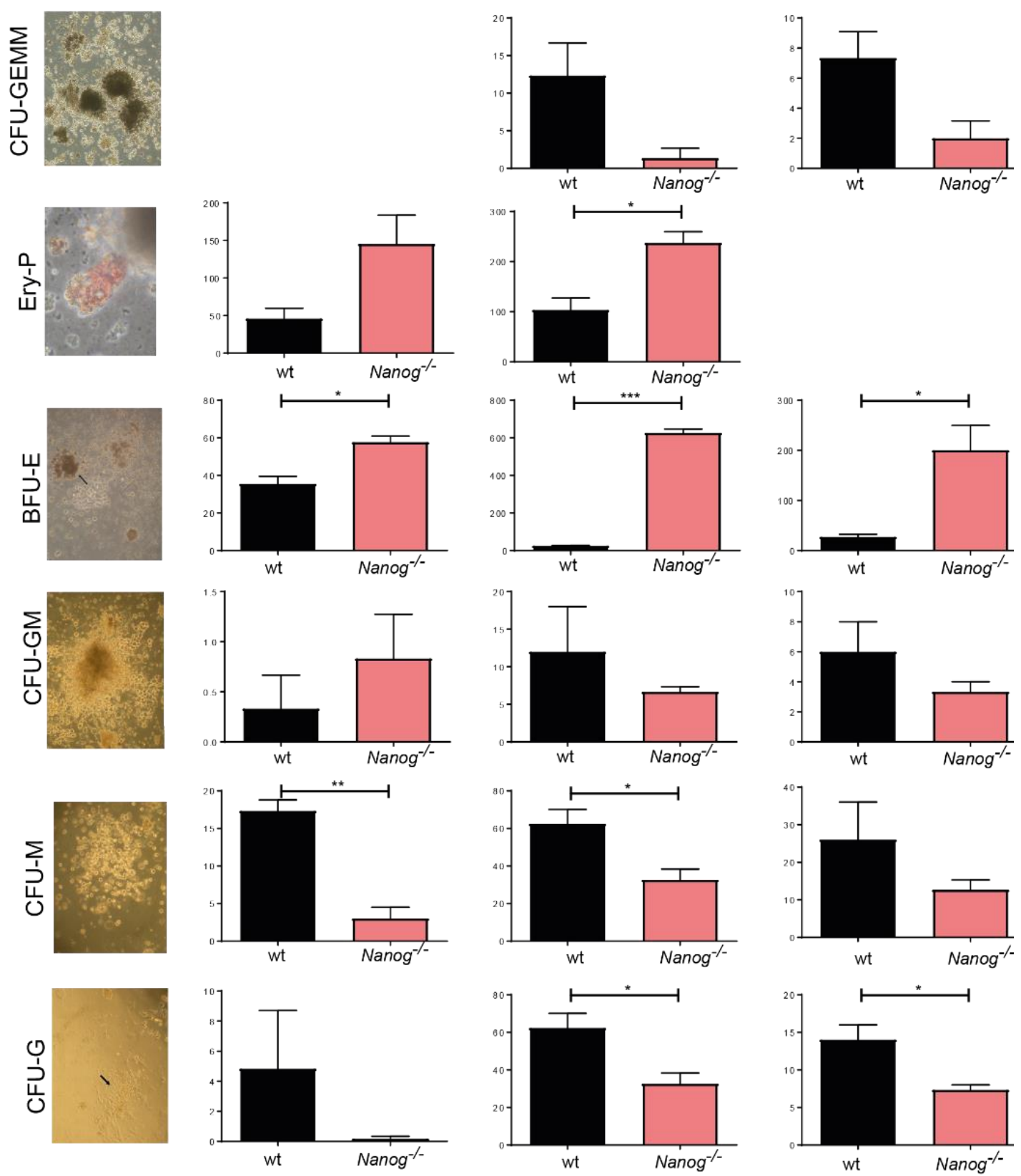

Figure 22. Nanog-knockout ES cells show increased potential to generate erythroid precursors: Quantification of colony-forming units generated by wild type (wt) and knockout $\left(\right.$ Nanog $\left.^{-1}\right)$ ES cells after culture of EBs for 5 (D5), 6 (D6), or 7 (D7) days and plating disaggregated cells in different hemogenic-promoting conditions $(n=3$, each with 3 technical replicates). Panels on the left show representative images of mouse hematopoietic colonies obtained after 12 days of culture in specific media. CFU-GEMM, progenitors giving rise to granulocytes, erythrocytes, monocytes, and megakaryocytes; BFU-E, burst forming unitserythroid; Ery-P, colony forming primitive erythroid; CFU-GM, granulocyte-monocyte precursors; CFU-M, monocyte precursors; CFU-G, granulocyte precursors. No CFU-GEMM are detected at D5 and no BFU-E at D7. ${ }^{*} P<0.05,{ }^{* *} P<0.005,{ }^{* * *} P<0.00005$. All statistics were performed with Student's t test. 


\subsection{Hematopoietic genes are expressed regardless of the delay in}

\section{Brachyury expression during differentiation of $\mathrm{Nanog}^{-/}$ES cells}

To investigate how the absence of Nanog affects the gene networks involved in erythroid specification, we monitored control and $\mathrm{Nanog}^{-/-}$ES-derived EBs for the expression of selected markers over 10 days of differentiation. Brachyury expression was examined as a marker of initial mesoderm specification, a necessary first step for the establishment of hematopoietic lineages (Fehling et al., 2003). Brachyury expression markedly increased at day 3 in wild type cells, as previously described (Robertson et al., 2000), but in Nanog-/ EBs this expression peak was delayed until day 5 (Fig 23).
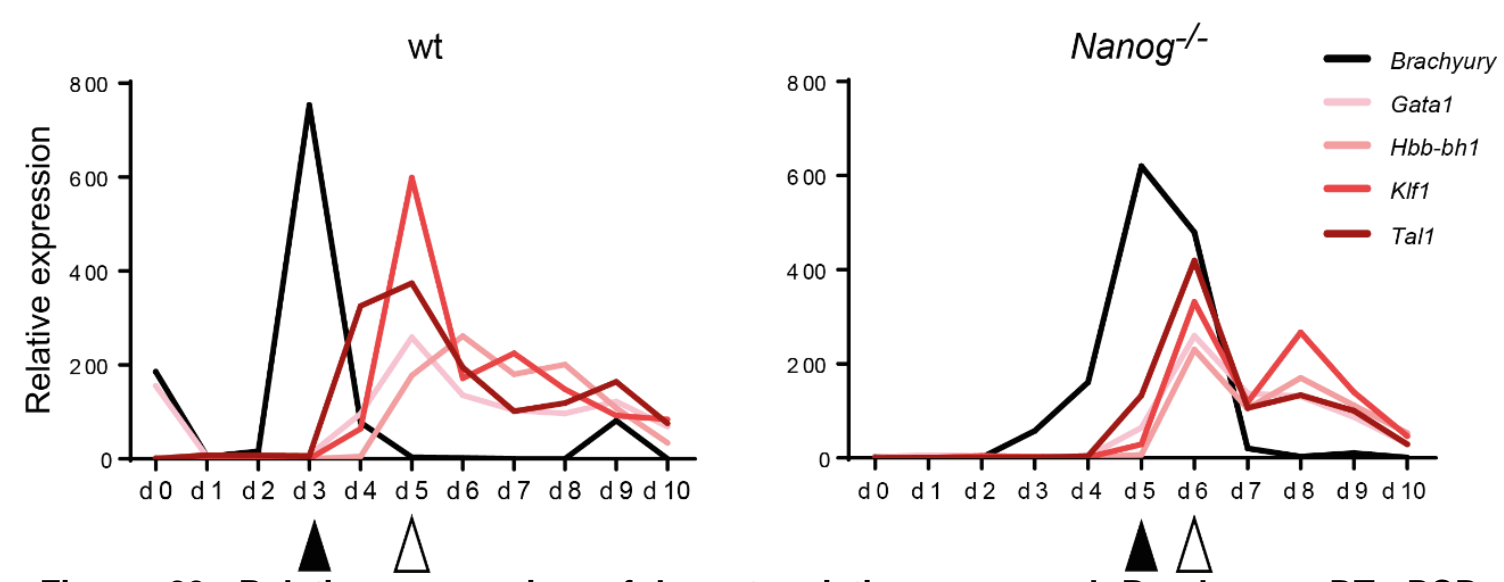

Figure 23. Relative expression of hematopoietic genes and Brachyury: RT-qPCR determination of the relative expression of Brachyury and selected hematopoietic genes in control (wt, left) and knockout (Nanog ${ }^{-}$, right) ES cells ( $n=3$ ) during 10 days of EB differentiation in hematopoietic-cytokine-enriched medium. Black arrowheads indicate the peak of Brachyury expression and white arrowheads the time of maximum hematopoietic-gene expression.

Nanog is thus likely required for the correct temporal activation of Brachyury during mesoderm specification. We next checked the expression of genes encoding the erythroid specific factors Tal1, Gata1, and Klf1 and the embryonic hemoglobin gene $H b b-b h 1$. In wild type EBs, erythroid gene expression peaks around day 5, 2 days after Brachyury activation. In Nanog ${ }^{-/}$EBs, erythroid gene expression peaked a day later, at day 6 . However, this is only 1 day after the onset of Brachyury expression, contrasting the 2-day delay in wild type EBs (Fig 23). Given the requirement of Brachyury expression for hematopoietic differentiation (Fehling et al., 2003), we aligned the expression dynamics of wild type and $\mathrm{Nanog}^{-/-}$cells to the day of Brachyury induction (Fig 24A). 


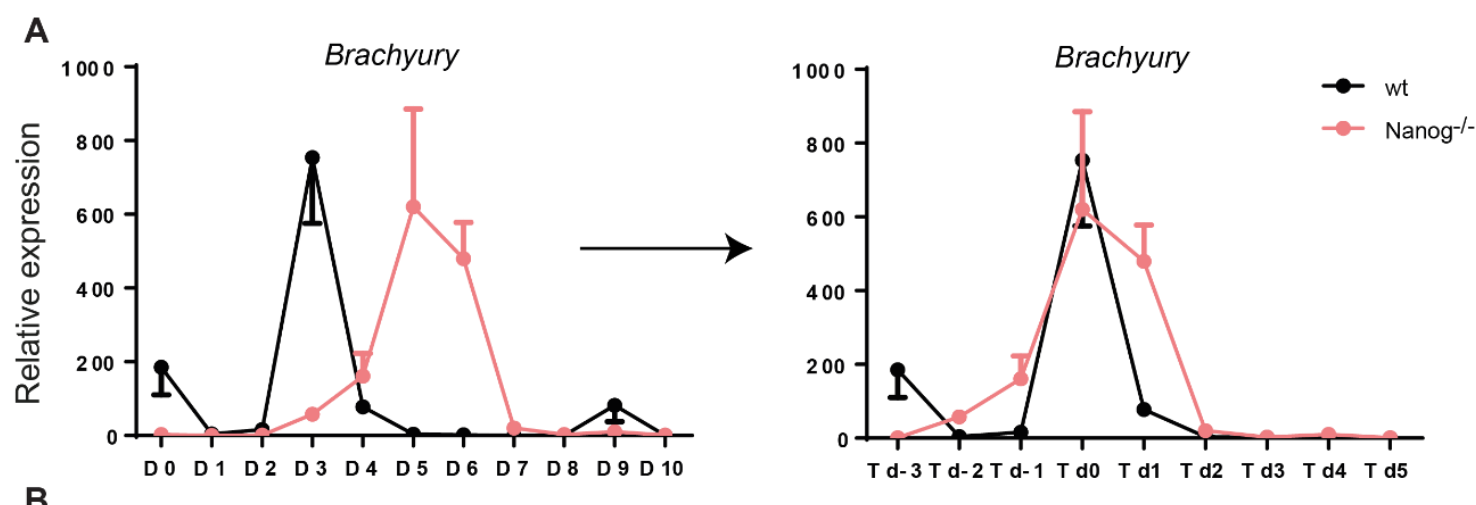

B
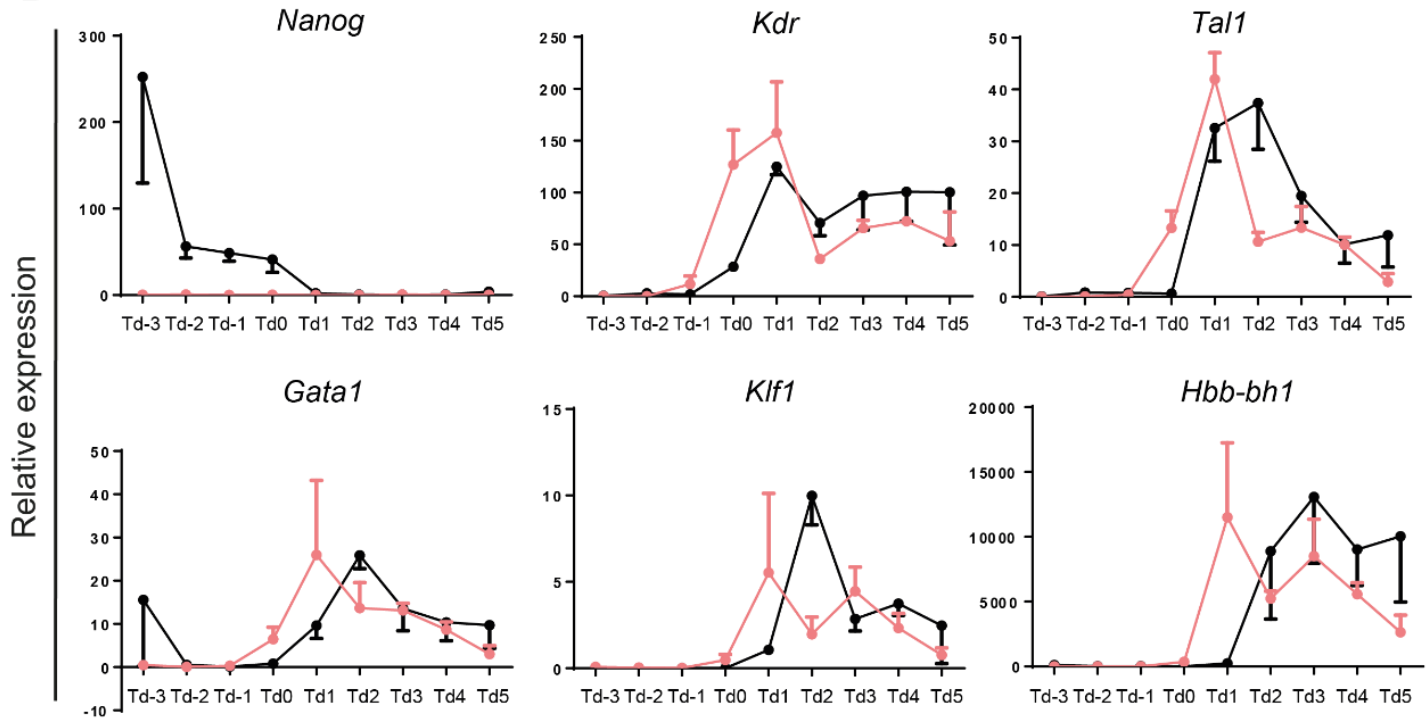

Figure 24. Expression profiles of hematopoietic genes during differentiation aligned at the peak of Brachyury expression: (A) Timing of Brachyury expression before (right) and after (left) the alignment of its peak of expression that occurs at day 3 (D3) of differentiation in wild type ES cells (wt, black) and at day 5 (D5) in Nanog/- cells (red). (B) Timing of expression of Nanog and selected hematopoietic genes when wt and $\mathrm{Nanog}^{/-}$cells after alignment. The time point of maximum Brachyury expression is labelled as T d0.

To validate this approach, we examined the expression of $K d r$, a panmesodermal gene that acts downstream of Brachyury; relative to the timing of Brachyury induction, dynamics of $K d r$ expression coincided in wild type and $\mathrm{Nanog}^{-1-}$ EBs. In contrast, Brachyury-referenced erythroid gene activation occurred earlier in Nanog ${ }^{-1-}$ EBs than in wild type controls (Fig 24B). Thus, although mesoderm induction is delayed in Nanog ${ }^{/-}$EBs, once it occurs the $\mathrm{Nanog}^{-/}$mesodermal cells show an elevated potential for erythroid differentiation. 


\section{Effects of Nanog gain-of-function on hematopoiesis in the adult mouse}

\subsection{Blockade of adult erythrocyte maturation by Nanog}

Nanog has been analyzed mainly in early developmental stages and in pluripotent stem cells. However, some reports have described its expression and role in adult tissues and cells (Kohler et al., 2011; Piazzolla et al., 2014; Tanaka et al., 2007). In light of our findings during embryonic hematopoiesis, we therefore explored the effects of Nanog during erythroid differentiation in the adult.

A

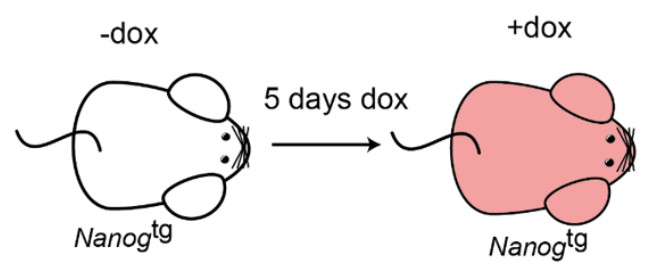

B

C
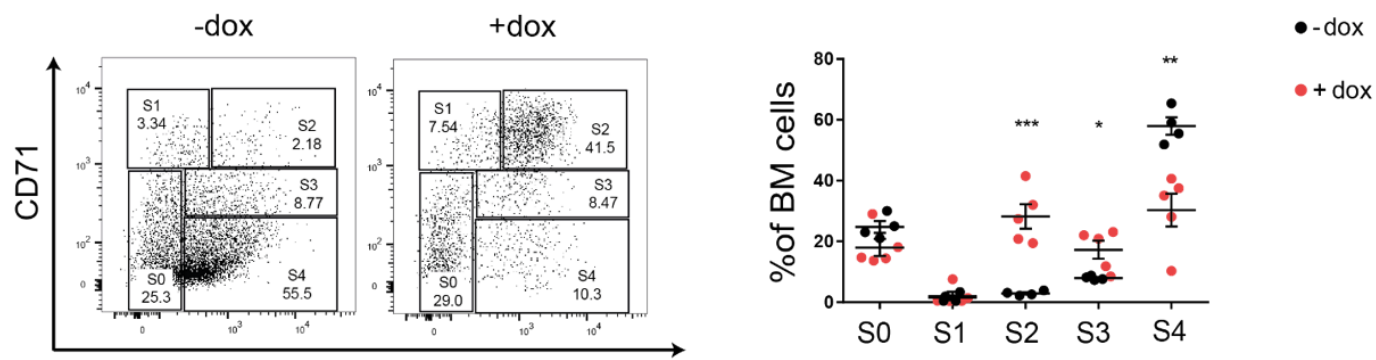

Ter119

Figure 25. Induced Nanog expression blocks erythroid maturation in adult mice: (A) Experimental design for the treatment of adult Nanogtg mice. (B) Representative FACS plots showing the distribution of different populations distinguished by CD71/Ter119 staining in whole bone marrow from untreated (-dox) or treated (+dox) adult mice. S0 (double negative cell), S1 (proerythroblast), S2 (basophylic erythroblast), S3 (polychromatic erythroblast), and S4 (orthochromatic erythroblast) are different stages of blood maturation. (C) Quantification of the S1-S4 erythroid populations (-dox, $\mathrm{n}=4 ;+$ dox, $\mathrm{n}=5$ ) ${ }^{*} P<0.05,{ }^{*} P<0.005,{ }^{* * *} P<0.0005$. All statistics were performed with Student's t test..

Nanog expression was systemically induced in adult Nanogtg mice by 5-day treatment with dox in drinking water, and the mice were then sacrificed and bone marrow extracted (dox+; Fig 25A). As controls, we used untreated mice of the same genotype (dox-). Analysis of erythrocyte maturation with CD71 and Ter119 (Socolovsky et al., 2001; Zhang et al., 2003) revealed an increase in immature populations (basophilic and polychromatic erythroblasts; S2 and S3, respectively) together with a decrease in the number of more differentiated erythrocytes 
(orthochromatic erythroblasts, S4; Fig 25 B,C). This result suggested a block in the differentiation of erythrocyte precursors.

\subsection{Differentiation of megakaryocyte-erythroid progenitors is blocked by Nanog}

After observing the effect on the last stages of differentiation of erythroid cells, we wondered if this phenotype could be also seen in earlier progenitors and whether defects will affect only erythroid lineage or if progenitors that give rise to other cell types would be affected as well.
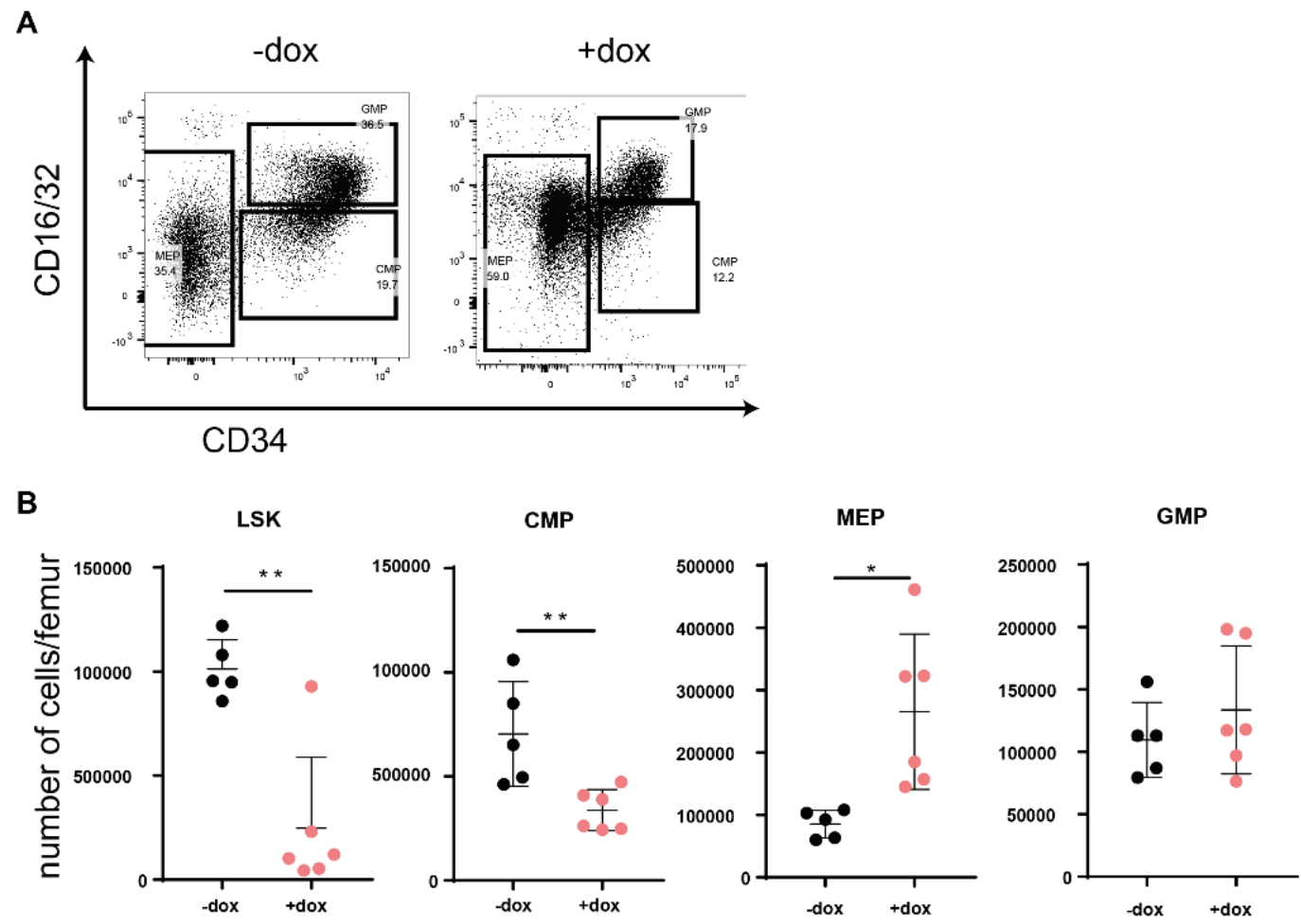

Figure 26. Induced Nanog expression increases MEPs in adult mice: (A) Representative FACS plots showing the distribution of CD16/32 and CD34 hematopoietic precursors sorted from the cKit+Sca1-LIN- bone marrow of untreated (-dox) or treated (+dox) adult Nanog ${ }^{\text {tg }}$ mice. (B) Quantification of precursor populations based on CD16/32 and CD34 sorting, as total number of cells per individual femur (-dox, $\mathrm{n}=5$; +dox, $\mathrm{n}=6) .{ }^{*} P<0.05,{ }^{* \star} P<0.005$; Student's ttest. 
Thus we quantified bone marrow progenitors by flow cytometry using lineage cocktail, ckit, Sca1, CD34 and CD16/32 (Fig 26A, Challen et al., 2009). Induced Nanog expression triggered a decrease in absolute cell numbers of hematopoietic stem cells (lineage-Sca1+cKit+; LSK) and common myeloid progenitors (CMP), but no changes in granulocyte-macrophage progenitors (GMP). Interestingly, this was accompanied by a significant increase in megakaryocyte-erythroid progenitors (MEP; Fig 26B). Therefore, we could see the effect of Nanog at different stages of erythrocyte development but not in any other cell type progenitor. The decrease in LSK and CMP could be attributed to the increase in production of MEPs that would consequently exhaust the earliest progenitors.

A
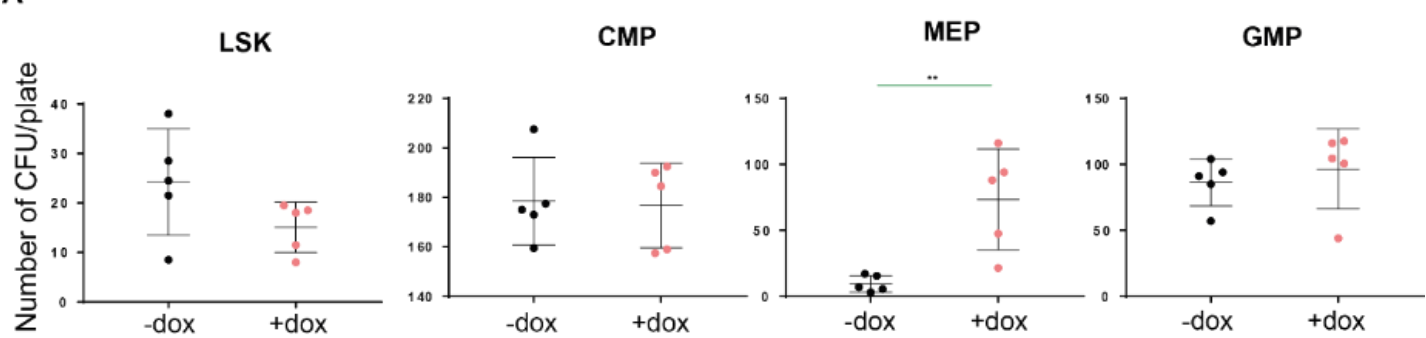

B
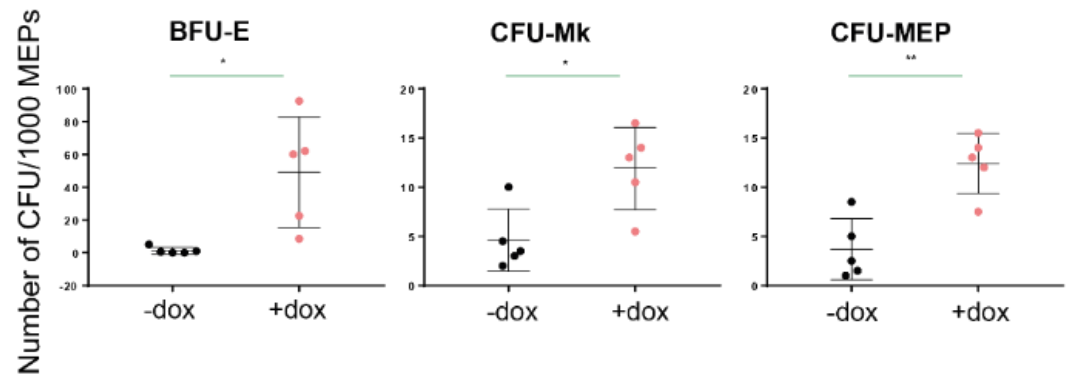

Figure 27. Induced Nanog expression blocks transiently the differentiation of MEPs: $(A)$ Quantification of total number of colony forming units (CFU) from 1000 cells of different sorted precursor populations. Only megakaryocyte-erythroid progenitors (MEP) show an increase in the progenitors (-dox, $\mathrm{n}=5 ;+$ dox, $\mathrm{n}=5$ ). ${ }^{* *} P<0.005$; Student's t-test. (B) Quantification of burst forming units-erythroid (BFU-E), colony forming units-megakaryocyte (CFU-Mk), and colony forming units of a mixed erythroid/megakaryocyte phenotype (CFU-MEP) present in 1000 cells of sorted MEPs per plate from untreated (-dox; $n=5)$ and treated (+dox, $n=5)$ individuals. Two plates were seeded with 1000 cells each as technical replicates. ${ }^{*} P<0.05,{ }^{\star *} P<0.005$; Student's t-test.

One question remained unanswered: whether the MEP population conserved their differentiation capabilities but was blocked by Nanog expression, or if on the contrary Nanog compromised the functionality of these progenitors, making them unable to further differentiate. 


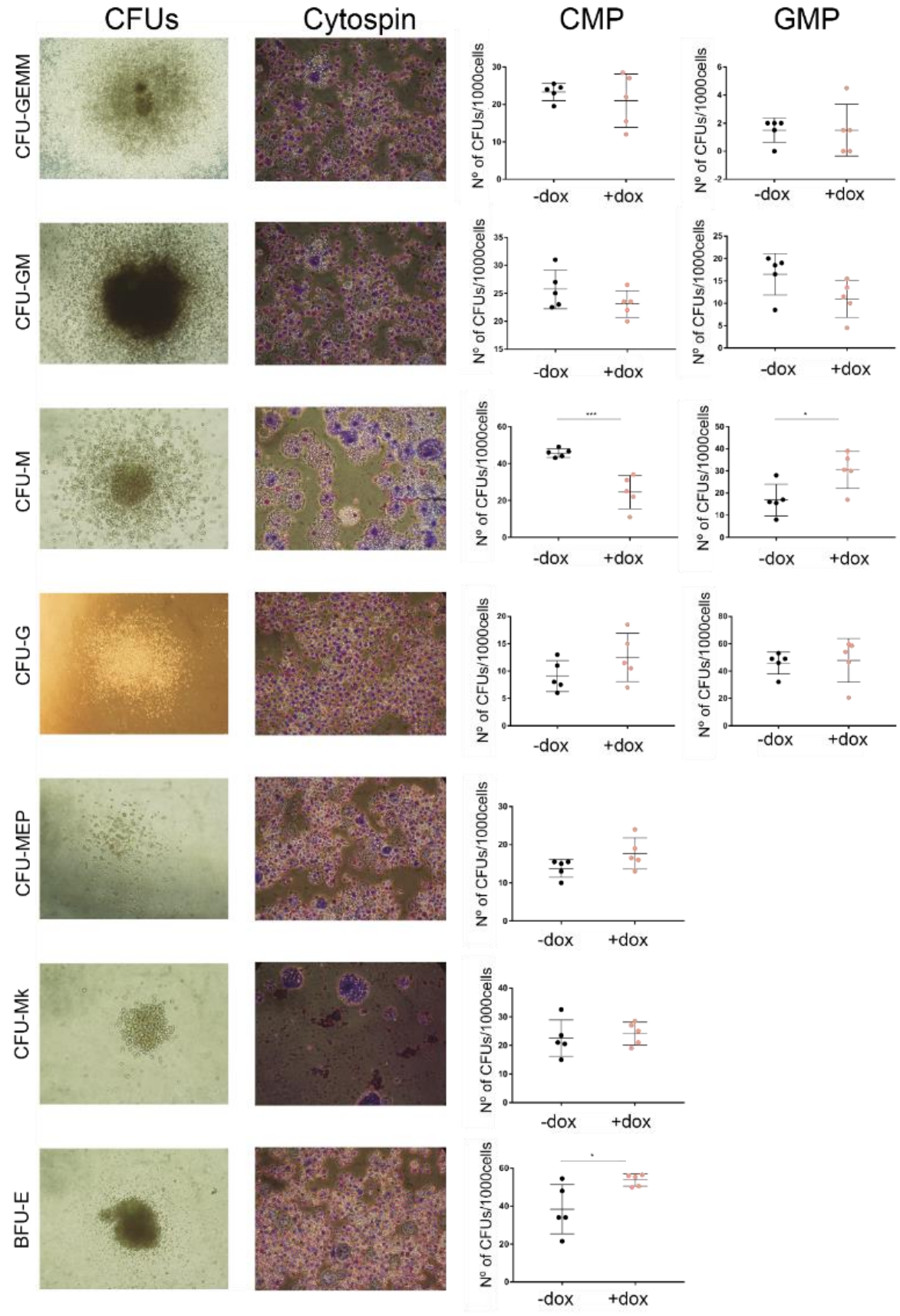

Figure 28. CFUs images, respective cytospinings and total counts of CMPs and GMPs: (CFUs) Representative images of mouse hematopoietic colonies obtained from adult bone marrow. CFU-GEMM, progenitors giving rise to granulocytes, erythrocytes, monocytes, and megakaryocytes; CFU-GM, granulocyte-monocyte precursors; CFU-M, monocyte precursors; CFU-G, granulocyte precursors, CFU-MEP, mixed erythroid/megakaryocyte precursors; CFUMk, megakaryocyte precursors; BFU-E, burst forming units-erythroid. (Cytospin) Representative images of selected spun CFUs (CMP) Quantification of different colony-forming units generated by 1000 cells of common myeloid progenitors (CMP) per plate isolated from untreated (-dox, $n=5)$ and treated (+dox, $n=5)$ Nanogtg adult mice. Two plates were seeded with 1000 cells each as technical replicates. ${ }^{*} P<0.05,{ }^{* \star} P<0.0005$; Student's t-test. (GMP) Quantification of different colony-forming units generated by 1000 cells of granulocytemonocyte progenitors (GMP) per plate isolated from untreated (-dox, $n=5)$ and treated (+dox, $\mathrm{n}=5)$ Nanog $^{\text {tg }}$ adult mice. Two plates were seeded with 1000 cells each as technical replicates. As expected, no CFU-MEP, CFU-MK or BFU-E were produced by GMPs. ${ }^{*} P<0.05$, Student's t-test. 
In order to investigate this issue we tested the differentiation capability of sorted populations from the bone marrow (LSK, CMPs, GMPs and MEPs) of dox treated and untreated mice by quantifying the colony forming unit (CFU) potential of each population in the absence of doxycycline (and therefore releasing the blockade of Nanog on the differentiation potential). Our hypothesis was that if Nanog was able to block the differentiation capacities, upon Nanog removal we would observe normal differentiation of CFUs; on the other hand, if Nanog is compromising the functionality of those cells irreversibly, we should observe a deficit in the production of CFUs.
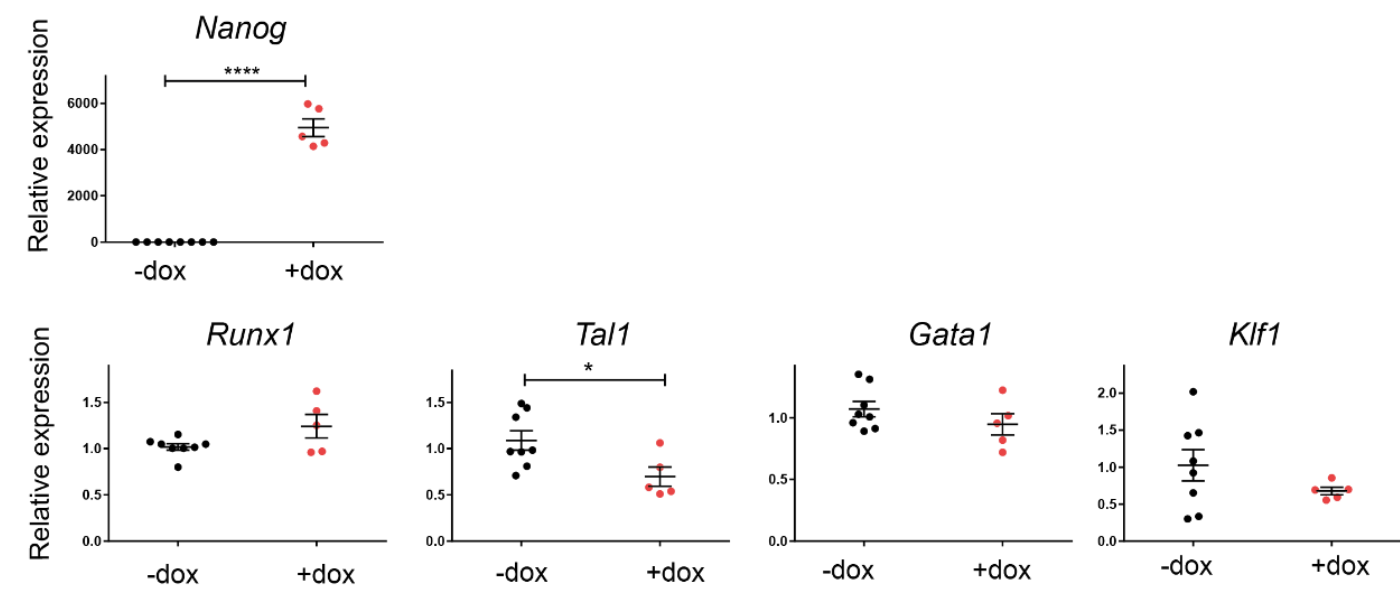

Figure 29. Induced Nanog expression downregulates specific hematopoietic genes in MEPs:RT-qPCR quantification of the relative expression of hematopoietic genes in megakaryocyte-erythroid progenitors (MEP) $(-$ dox, $\mathrm{n}=8 ;+$ dox, $\mathrm{n}=5) .{ }^{*} P<0.05,{ }^{* \star *} P<0.00005$; Student's t-test.

We observed that only MEPs from dox-treated mice generate significantly more CFUs than controls (Fig 27A). This was also the case when BFU-E (burst forming unit-erythroid), CFU-Mk (colony forming unit-megakaryocyte) or colony forming units of a mixed erythroid/megakaryocyte phenotype (CFU-MEP) where measured (Fig 27B). CMPs and GMPs from treated and untreated mice showed similar differentiation potential, with the exception of BFU-E from CMPs, or monocyte progenitors (CFU-M) that where increased by Nanog in GMPs but decreased if derived from CMPs (Fig 28). Analysis of the expression of key erythroid genes by RT-qPCR in sorted MEPs revealed a significant reduction of Tal1 in dox-treated mice (Fig 29). Together, these results indicate that Nanog is not altering the functions of the MEPs, but is specifically blocking transiently the 
differentiation of these precursors. This leads to defective differentiation of these populations and therefore to an accumulation of their progenitors together with an exhaustion of the CMPs that do not present any impairment in functionality by CFU assay.

\subsection{Nanog-expressing MEPs are outcompeted by the host in bone marrow transplants}

To extend these observations, we next carried out transplantation of bone marrow from Nanog ${ }^{\text {tg }}$ mice to wild type recipients irradiated with 11 grays $(5.5+5.5)$. After 3 months of engraftment and recovery, more than $95 \%$ of peripheral blood cells were derived from the transplant ( $n=7 ;$ Fig 30). We treated the mice for 4 months with dox to induce Nanog expression only in hematopoietic cells, and found that at that point the host cells had been partially able to recolonize the bone marrow and contribute to circulating cells (ranging from $20 \%$ to $80 \%$; Fig $30 \mathrm{~A}$ ).

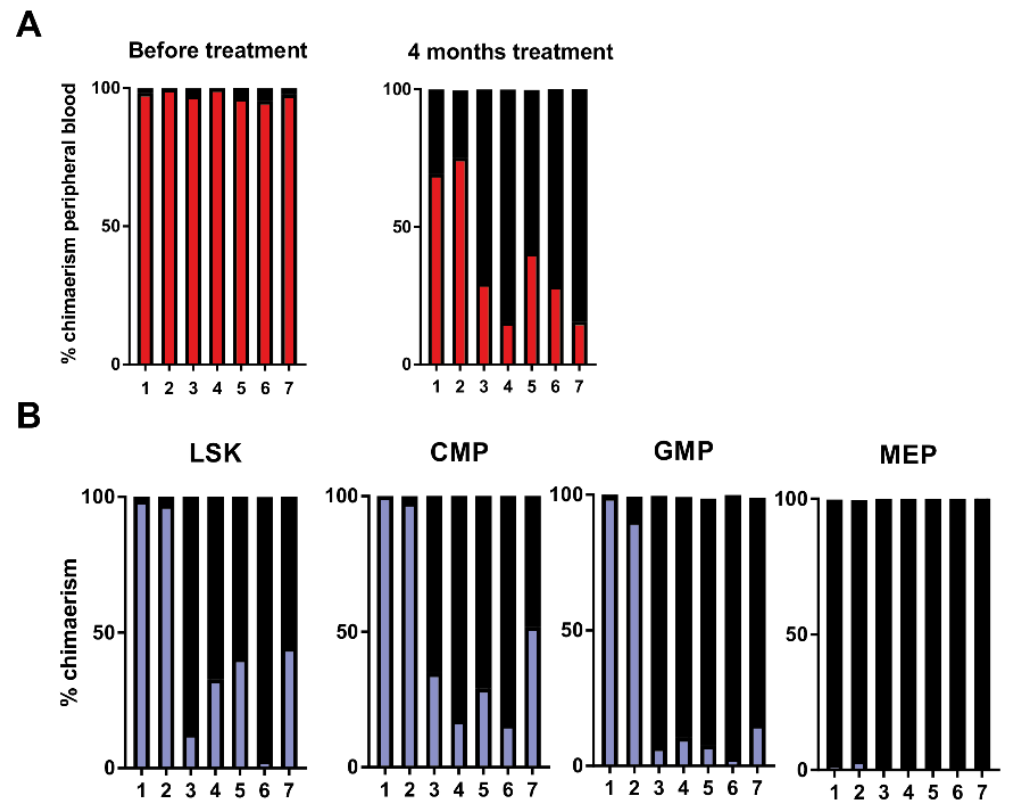

Figure 30. Nanog tg transplanted bone marrow cells do not contribute to MEPs in a competitive transplant: (A) Contribution of Nanogtg transplanted bone marrow cells to peripheral blood before (left) and after (right) dox treatment. Percentage of host derived cells (CD45.1+) are shown in black, and of donor derived cells (CD45.1/CD45.2 double + ) in red. Individual mice are indicated on the $x$-axis $(n=7)$. (B)Contribution of Nanog to transplanted cells to LSK, CMP, GMP and MEP populations purified from bone marrow. Percentage of host derived cells (CD45.1+) are show in black, and of donor derived cells (CD45.1/CD45.2 double $+)$ in blue. Individual mice are indicated on the $x$-axis $(n=7)$.

We then purified bone marrow from the transplanted mice and analyzed chimaerism in different progenitor populations. While LSK, CMPs or GMPs show 
variable degrees of contribution of wild type cells and Nanog expressing cells, MEPs are almost exclusively derived from the host (Fig 30B). These results indicate that the expression of Nanog in MEPs causes them to be outcompeted by wild type cells during bone marrow reconstitution, possibly due to their decreased ability to differentiate and generate mature erythroid cells.

\section{Tal1 is a target of Nanog at gastrulation}

\subsection{Nanog expression is mutually exclusive with that of Tal1 in the nascent mesoderm}

Nanog-mediated downregulation of erythroid-specification genes in both the embryo and the adult strongly suggests that some of these genes are likely transcriptional targets of NANOG. If so, we would expect to find mutually exclusive expression of Nanog and these genes at the time of initial hematopoietic specification in the gastrulating embryo. We therefore analyzed single-cell expression data from E7.0 nascent mesoderm (Scialdone et al., 2016), when Nanog is still expressed in the posterior-proximal region of the embryo (Hart et al., 2004), and examined the number of cells expressing both Nanog and markers of mesoderm (Brachyury, Cdx2) and hematopoiesis (Tal1, Runx1, Gata1, KIf1) (Fig 31A).
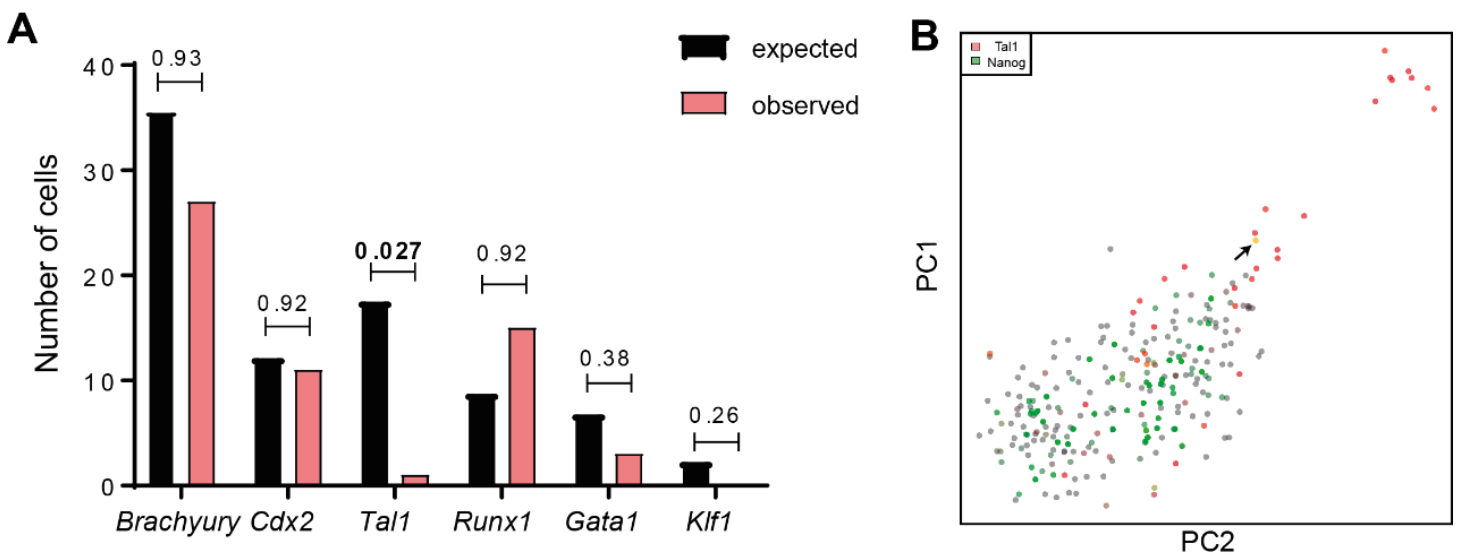

Figure 31. Tal1 and Nanog are mutually exclusive in nascent mesoderm cells: (A) Expected (in black) and observed (in red) number of mesodermal (Flk1+) cells of the E7.0 mouse embryo expressing Nanog and selected genes expression, on single cell RNA-seq data (Scialdone et al., 2016). Statistical significance was calculated with a hypergeometric test. (B) Principal component analysis showing the distribution of Flk1+E7.0 mesoderm cells expressing Nanog (green) or Tal1 (red). The single cell expressing both genes is shown in yellow and indicated by an arrow. 
For all of these genes we found the expected proportion of co-expressing cells with Nanog with the exception of Tal1 (Fig 31A, B), this proportion is directly correlated with the number of cells expressing said genes. We confirmed that Nanog can downregulate Tal1 at early stages by culturing Nanog ${ }^{\text {tg }}$ embryos with or without dox from E6.5 to E6.75 ex-utero, which did not alter normal development (Fig 32A). Tal1 failed to be upregulated in dox-treated embryos, whereas other hematopoietic genes such as Klf1 were unaffected (Fig 32B). We further confirmed that Nanog downregulates Tal1 by whole mount in situ of E7.0 embryos treated with dox in utero (Fig 32C).

A

C
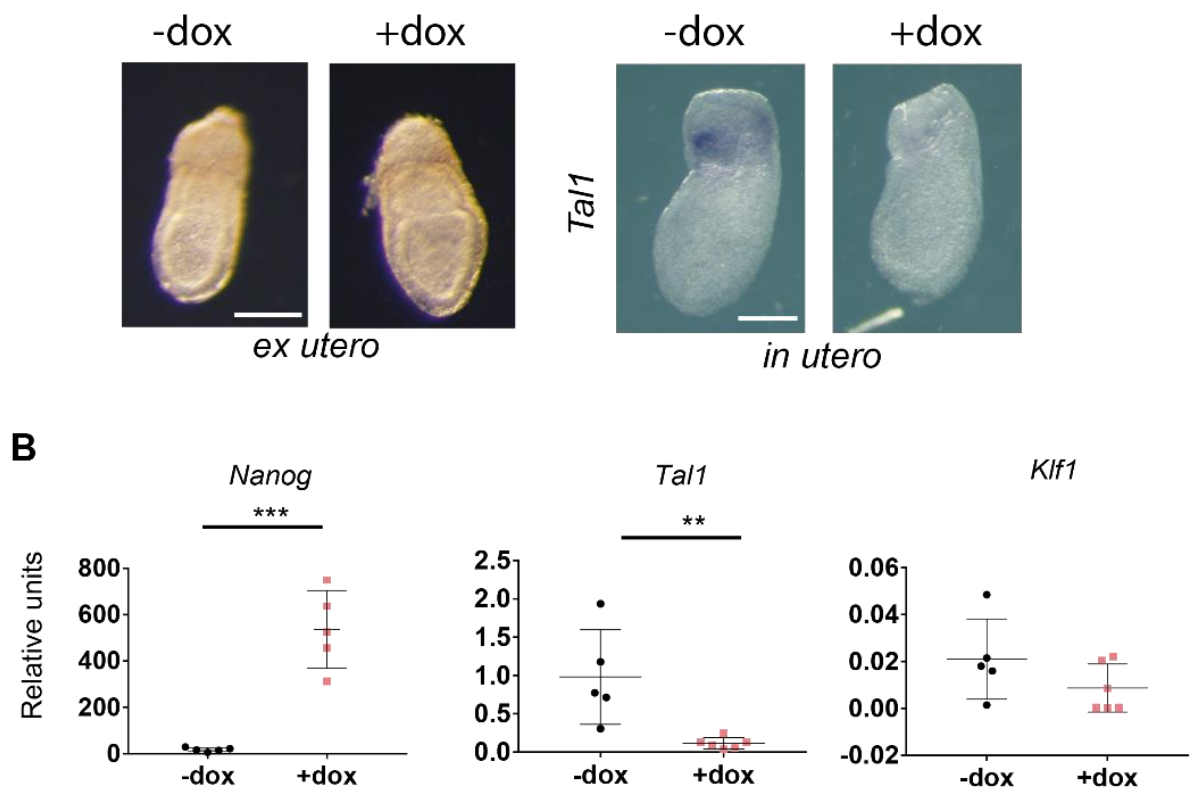

Figure 32. Nanog downregulates Tal1 expression at the onset of gastrulation: (A) E6.5 Nanog ${ }^{\text {tg }}$ embryos after 8 hours ex-utero culture in the presence (+dox) or absence (-dox) of doxycycline. Scale bar, $100 \mu \mathrm{m}$. (B) RT-qPCR quantification of the relative expression of Nanog, Tal1, and Klf1 in individual untreated embryos (-dox) or treated embryos (+dox) $(n=5)$. ${ }^{* *} P<0.005$, ${ }^{* *} P<0.0005$; Student's t-test. (C) Whole mount in situ hybridization of Tal1 in E7.5 untreated (-dox) or in utero treated (+dox) Nanog ${ }^{\text {tg }}$ embryos.

This evidence strongly suggests that Tal1 is likely a target of NANOG during early gastrulation at the onset of hematopoietic determination. 


\subsection{A distal NANOG-binding element represses Tal1 expression in the embryo}

To investigate the possible direct regulation of Tal1 by NANOG, we analyzed published ChIP-seq data for NANOG binding in ES and epiblast-like cells (EpiLCs), which correspond to the E6.0 epiblast in the mouse embryo (Murakami et al., 2016). This study describes a broad resetting of NANOG-occupied genomic regions in the transition from ES cells to EpiLCs, resembling the developmental progress from the naïve inner cell mass of the blastocyst to the primed epiblast at gastrulation (Hayashi et al., 2011; Morgani et al., 2017). We examined a number of genomic loci, detecting binding at the Nanog locus itself in both ES cells and EpiLCs (Fig 33A) and in Cdx2 only in ES cells (Fig 33B).

Neither cell type showed evidence of NANOG-bound regions surrounding Runx1 (Fig 33C) or Klf1 (Fig 33D). Interestingly, EpiLCs, but not ES cells, showed NANOG binding 22 kilobases upstream of Tal1, in an intron of the neighboring Stil gene (Fig 33E). We also detected NANOG binding downstream of Gata1 (Fig 33F). However, these regions could be functionally related to the neighboring Eras and Hdac6 genes, which are associated with pluripotency and early stemcell differentiation (Chen et al., 2013, Takahashi et al., 2003).

Analysis of the Tal1/Stil NANOG-bound region in EpiLCs (Fig 34A) revealed bona-fide consensus binding sites (Fig 34B). To investigate the function of this region, we deleted it by CRISPR/Cas9 mediated genome editing (Ran et al., 2013) and examined the transcriptional consequences in early development. Gene expression was analyzed by RT-qPCR in individual edited E6.5 embryos.

As controls, we used embryos of the same batch showing no evidence of deletion of the Tal1/Stil NANOG bound region (Fig 34C). Tal1 expression was significantly increased in deleted embryos, whereas other genes such as Klf1, Gfi1b or Runx1 were unaffected (Fig 34D). Deletion of this genomic region did not alter Stil expression, despite the location of the site within this gene (Fig 34A,D). These assays provide strong evidence that this specific genomic region acts as a cisregulatory element in the Nanog-mediated repression of $T a / 1$ in the early mouse embryo. 
A

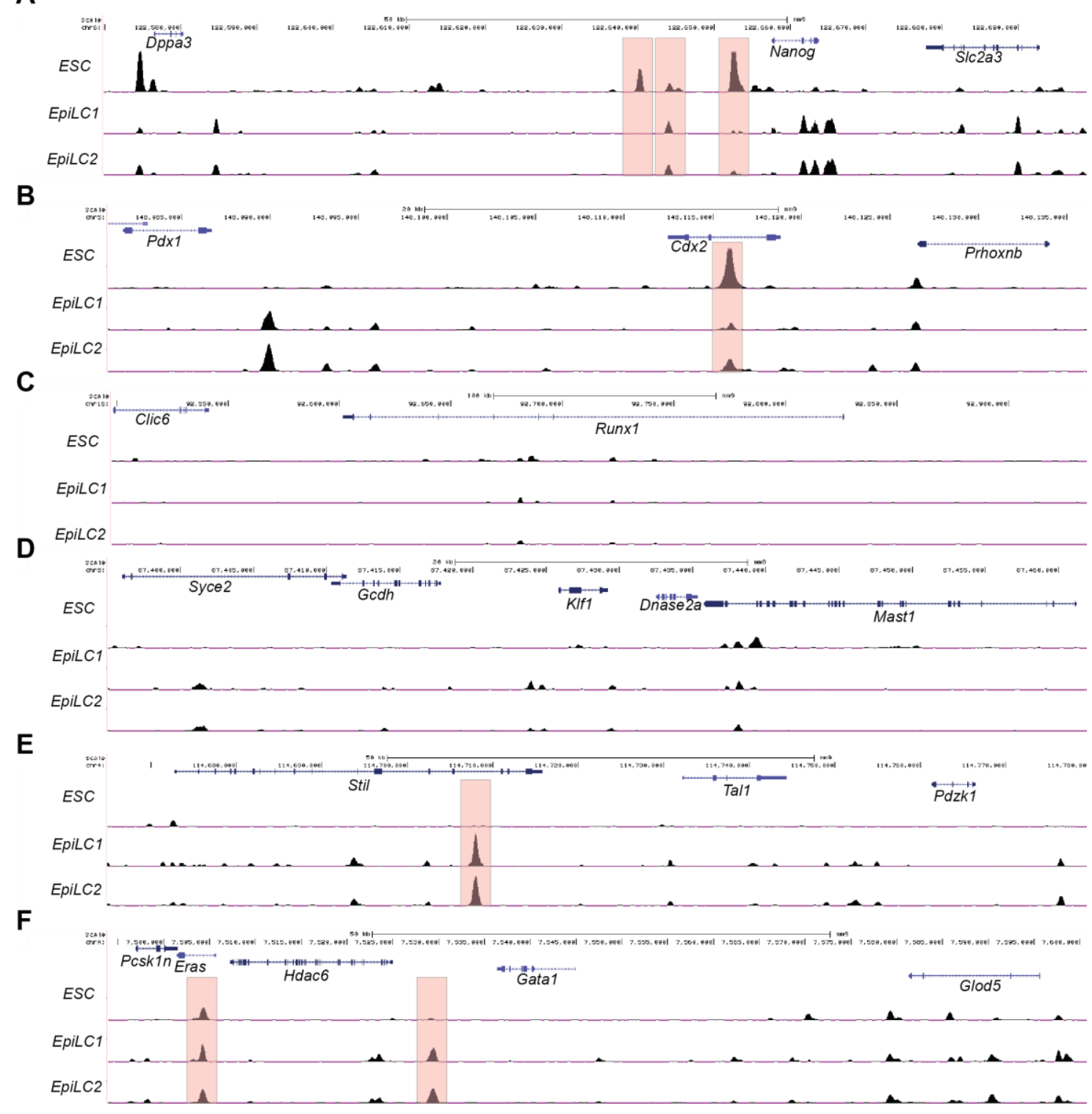

Figure 33. Distribution of NANOG bound regions at selected loci in ES and Epi-like cells (EpiLC): (A-F) UCSC browser views (mm9) of different genomic regions showing NANOG bound regions as determined by ChIP-seq in ES cells $(E S C)$ and two replicates of epiblast-like cells (EpiLC1, EpiLC2). Selected peaks are highlighted by boxing in red. (A), Nanog: chr6:122,569,855-122,699,399. (B), Cdx2: chr5:148,080,850-148,136,544. (C), Runx1: chr16:92,497,828-92,940,224. $\quad$ (D), Klf1: chr8:87,395,041-87,462,459. (E), Tal1: chr4:114,664,868-114,780,341. (F), Gata1: chrX:7,493,906-7,601,563. ChIP-seq data was obtained from Murakami et al. 2016 (GEO accession number GSE71933).

Regulation of the earliest stage of RBC formation is still not well understood. Beside information extracted from lineage tracing experiments and early hematopoiesis genes deletion, not much is known about this process in vivo (Padrón-Barthe et al., 2014; Porcher et al., 1996; Shivdasani et al., 1995; Tam and Beddington, 1987). 
Here we have described a new role for Nanog blocking erythroid differentiation. This effect is probably due to Nanog repressing Tal1 in the early gastrulating embryo, a transcription factor crucial for the mesoderm-to-RBC induction. Furthermore, this repressive role of Nanog upon Tal1 can apparently take place throughout development up to the adult bone marrow.

A

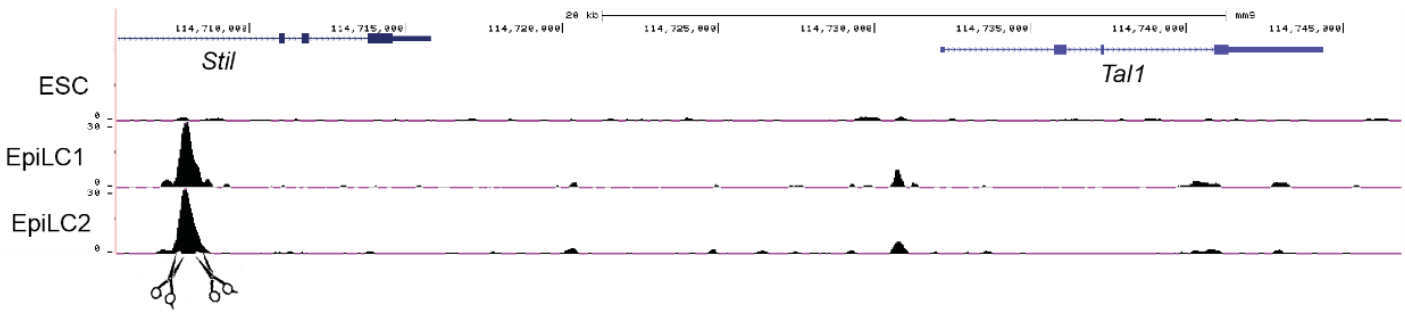

B

mm9, chr4:114707745-114708744

ATGAGACCAGTGCAAACTGTATAGAACAACCCTGCCCTGAAAAACAAAACAAAACAAAAC ATTTCCAGAGCTGTCCGTGGTGGCTTCGGTGCTGTTGCGCAAGCATCTAGTCTGACTCAT P GCTGTGGCTCTCATTGCTCAGTATTCATCGTGTCATTAGCTCCCTGGGCTCCCAGATCAG CCAGTCGTGTGCTGCTGGAGCAGTCTCTAAAGATGAGTTATTGGCTGTACAGCTTATT GGCTATCGATTGCTTTTTCCCAATGGAAAGTGATGGTACAAGGAGACATTGTTTAAAACA ACTGTTTAAGAAGCCATGCCAAATTTGCAGGTAATGGCACATTGAAGTCATTGTTTAAAA

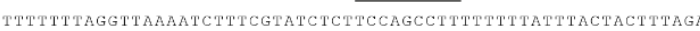

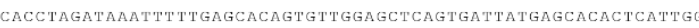
CTCAAGCTTCTGATTTTAGTCATGGCTATGAACTTTTCTCTGCTCCCTGGTTGACCTATC

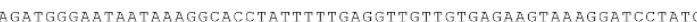
TCATCAGTCAGAACAGTGCCTGCCACTGGGTAGCCAGCGTTTGTTTGGTGGTGAATACTC TGAAAGCAGGAGATTATGTGGCTTTTGCTTTCAGTCCTAGCAGCTGGCTCCAGTGCTGTC GGCTGTTGGTGATTCTGTCGCATATGGCAGGACACAGAACCTGAGCTCGGGAGTGGACTI TCTTCACCCTCCCCCCCAGCGGATTAGACAATGCTGTCCACATTCCGGGCTGCTCTTCTC TCAGTTGCTGTTCCTCTGTAAAATGCCCTCACAGACACACCTGCAGTGT GCTTTAGGAAT CTCCCAGGCAAGACTACTCACCATCACAGTGTTMATCACGATGGTCATTTAGTAAAAA TggaAtaAgCCACATtCAgTAACTgGCATgGaCtCtCAgA
C
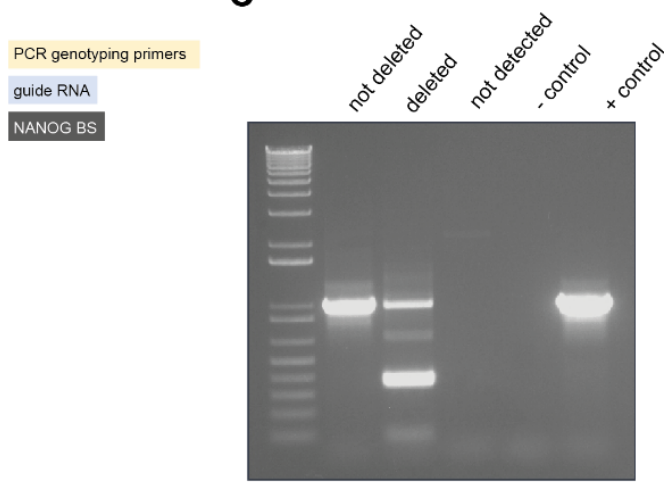

D

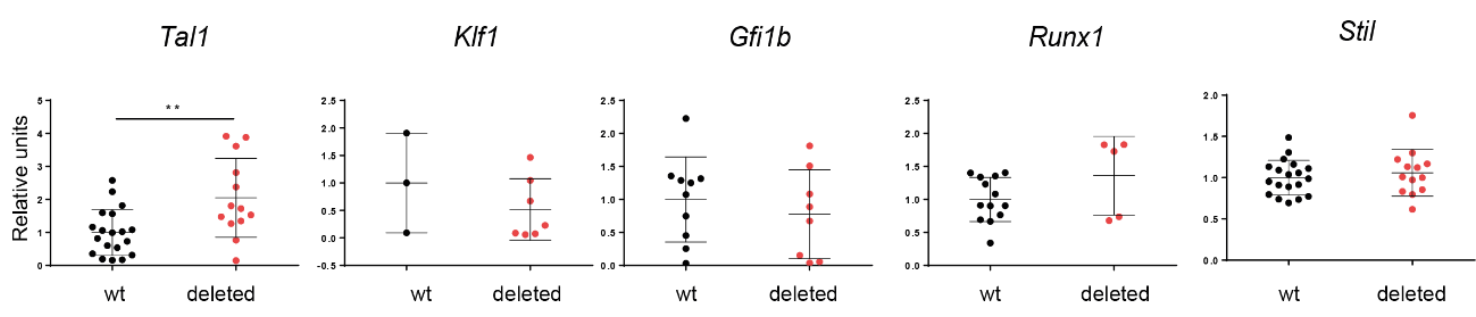

Figure 34. CRISPR/Cas9 deletion of the Tal1 NANOG binding peak: (A) UCSC browser view of the Tal1/Stil1 region (mm9; chr4:114,705,753-114,756,741), indicating the presence of the NANOG binding peak, determined by ChIP-seq, in EpiLCs (2 replicates are shown) but not in ES cells (Murakami et al., 2016); the binding peak was deleted by CRISPR/Cas9 genome editing (scissors). (B) DNA sequence of the genomic region located at $-22 \mathrm{~kb}$ from Tal1 bound by NANOG in EpiLC. PCR genotyping primers are highlighted in yellow, guide-RNAs in blue (PAM sequence is underlined), and two consensus NANOG binding motifs in dark grey and white bold lettering. (C) Representative gel of PCR-genotyping of individual E6.5 embryos showing not deleted, deleted, not detected, negative control (no DNA) and positive control (wild type embryo). (D) RT-qPCR determination of relative expression of Tal1 (19 wt, 13 deleted), Klf1 (3 wt, 7 deleted), Gfi1b (10 wt, 8 deleted), Runx1 (13 wt, 5 deleted) and Stil (19 wt, 13 deleted) in wild type and CRISPR-deleted embryos. ${ }^{*} P<0.05,{ }^{* \star} P<0.005$, Student's t-test. 


\section{Regulation of anterior fates in the epiblast by Nanog}

As we have previously shown, Nanog expression beyond gastrulation produces two marked and distinct phenotypes: lack of red blood cells and cranio-neural defects. This later phenotype could be due to the anteriorization of the expression of Nanog. At E6.5, Nanog is only expressed in the posterior region of the embryonic epiblast. It is at this stage that anterior and posterior fates are determined. Hence, ectopic expression of Nanog in the anterior epiblast could be inducing early defects that result in the phenotype we observe at E9.5.

Specification of anterior and posterior territories occurs right before gastrulation and represent the earliest event in differentiation process of pluripotent cells. At this stage, what were pluripotent cells enter a primed state from which they are more prone to differentiate. Thus we decided to study this process in vitro with Nanog ${ }^{K O}$ ES cells at the exit of pluripotency.

\subsection{Lack of Nanog upregulates anterior neural genes at the exit of naïve pluripotency}

In order to explore the role of Nanog and identify putative targets at the transition from pluripotency to lineage specification, we did an RNAseq of ES cells in differentiation media for $24 \mathrm{~h}$. We used Nanog ${ }^{\mathrm{KO}}$ ES cells and the parental ES cell line from which they were derived as wildtype controls (Chambers et al., 2007a). Cells were cultured with 2i/LIF/KOSR for two passes and subsequently changed to serum to induce exit from pluripotency (Heo et al., 2005; Martin Gonzalez et al., 2016). To be able to follow the earliest events taking place in this process, we took samples at zero, 12, and 24 hours after adding serum to the culture (Fig 35A). We were interested in the first stages of differentiation because Nanog rapidly disappears from differentiating cells, and it is in these first stages in which genes of anterior or posterior character start to be expressed. 
A

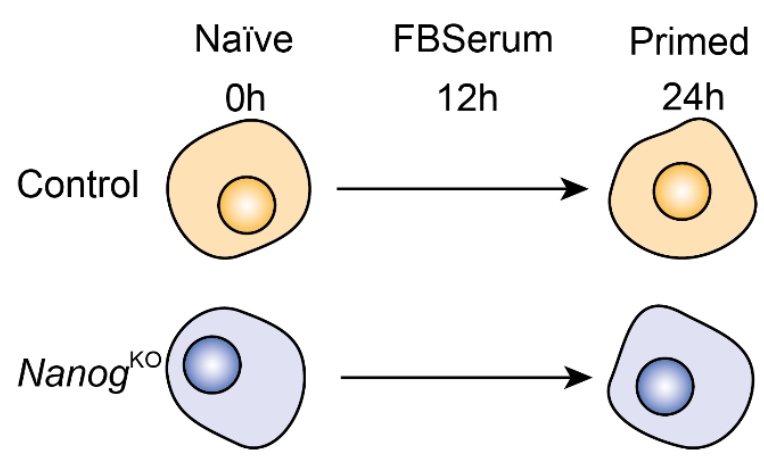

B

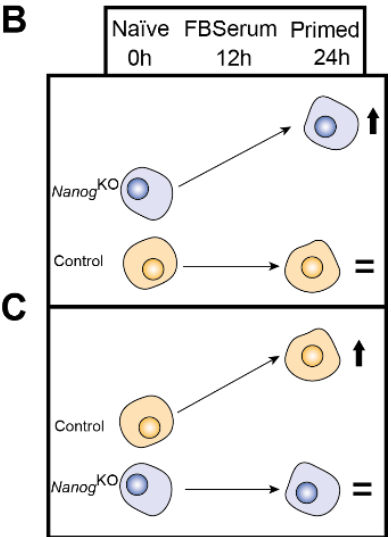

Figure 35. ES cells differentiation model and set up: (A) Three time points were taken during ES cells priming: $0 \mathrm{~h}, 12 \mathrm{~h}$ and $24 \mathrm{~h}$ per triplicate. (B,C) Graphical model of the different group of genes we expect: (B) Genes upregulated in KO conditions during priming of ES cells and $(C)$ genes upregulated in control conditions during priming of ES cells.

At these early stages of ES cell differentiation, changes in the patterns of expression could point us towards genes directly regulated by NANOG. To analyze the differences we looked for genes that changed their expression dynamics from zero to 24 hours (Table S1). Genes with a stable trend of expression in control ES cells that show and increase in Nanog KO cells would point to genes that are repressed by Nanog (Fig 35B), while genes with the opposite behaviour (that is, activated in controls but that do not change in mutant cells) would be positively regulated by Nanog (Fig 35C).

Principal component analysis (PCA) of the RNA-seq data showed a clear separation of the samples based on genotype of the cells (PC1, that explains close to $40 \%$ of variability; Fig 36), and timing of differentiation (PC2, 25\% of variability; Fig 36). It is also interesting to observe that time oh samples differentiate more from their respective $12 \mathrm{~h}$ and $24 \mathrm{~h}$, indicating that a mayor change in the transcriptome is occurring in the first 12 hours. 


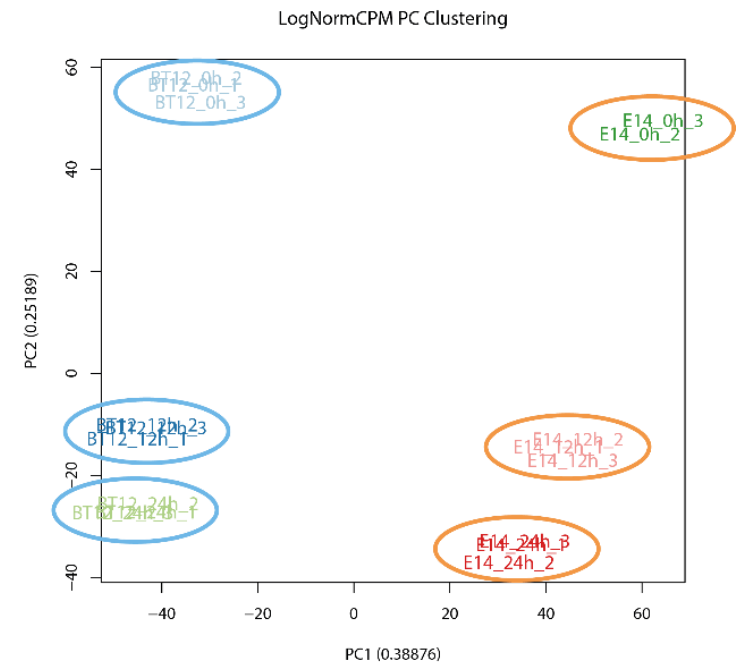

Figure 36. PCA showing sample and time distribution. Barcode of each sample goes as follows: 1 . BT12 and E14 are Nanog KO ES cells and the parental ES cell line respectively. 2. Times are marked as $0 \mathrm{~h}, 12 \mathrm{~h}$ and $24 \mathrm{~h}$. 3. Different replicates are assigned numbers from 1 to 3. Samples circled in blue are Nanog KO ES cells and in orange are parental ES cells

Interestingly, the comparison at time 0 between control and mutant ES cells showed minimal if any differences in the expression of core pluripotency genes (Fig 37), in line with previous observations on the dispensability of Nanog at the pluripotent state (Chambers et al., 2007a).

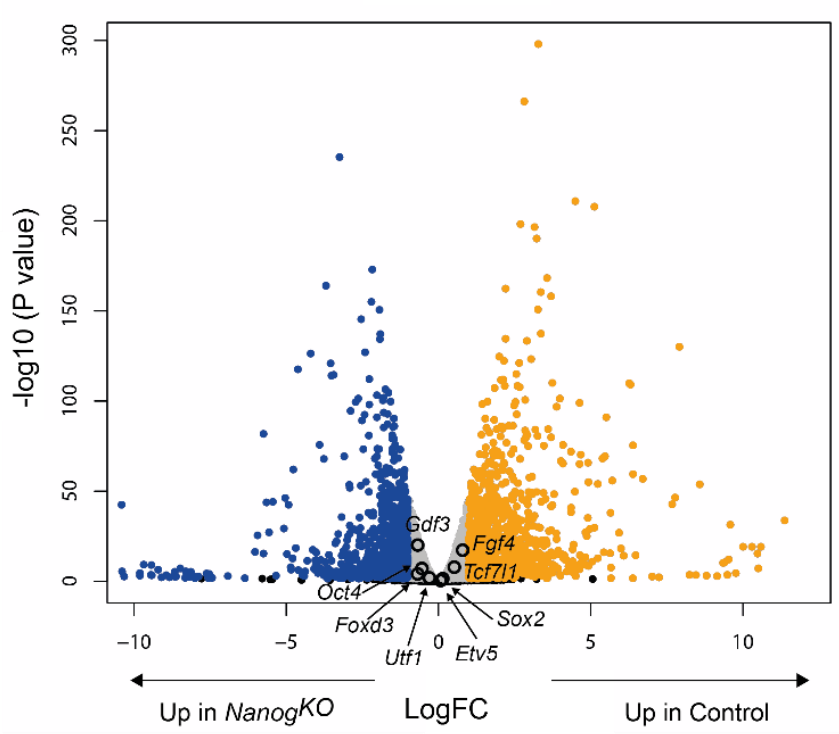

Figure 37. Volcano plot of the comparison at $0 \mathrm{~h}$ between $\mathrm{Nanog}^{\mathrm{KO}}$ and control ES cells: In blue, we find genes upregulated in Nanog ${ }^{K O}$ cells. In orange, genes upregulated in control cells. In grey genes that have less than [0.5] Log Fold Change (LogFC). In black genes with more than 0.05 adjusted $P$ value. Core pluripotency factors are indicated. 
We analyzed changes to gene expression taking into account their behaviour over time (Fig 35B, C), identifying two clear clusters with the predicted pattern of change (Fig 38A,B,C). Upregulated genes in mutant cells (89 genes) were mostly related to anterior neural development, such as Pou3f1 or Sox8 (Bell et al., 2000; O'Donnell et al., 2006; Zhu et al., 2014) (Fig 38A, D). On the other hand, genes that lost their upregulation in mutant cells (55 genes) were mainly involved in mesoderm as for example Mef2c or Hand2 (Fig 37B, E) (Reichenbach et al., 2008; Skerjanc et al.).

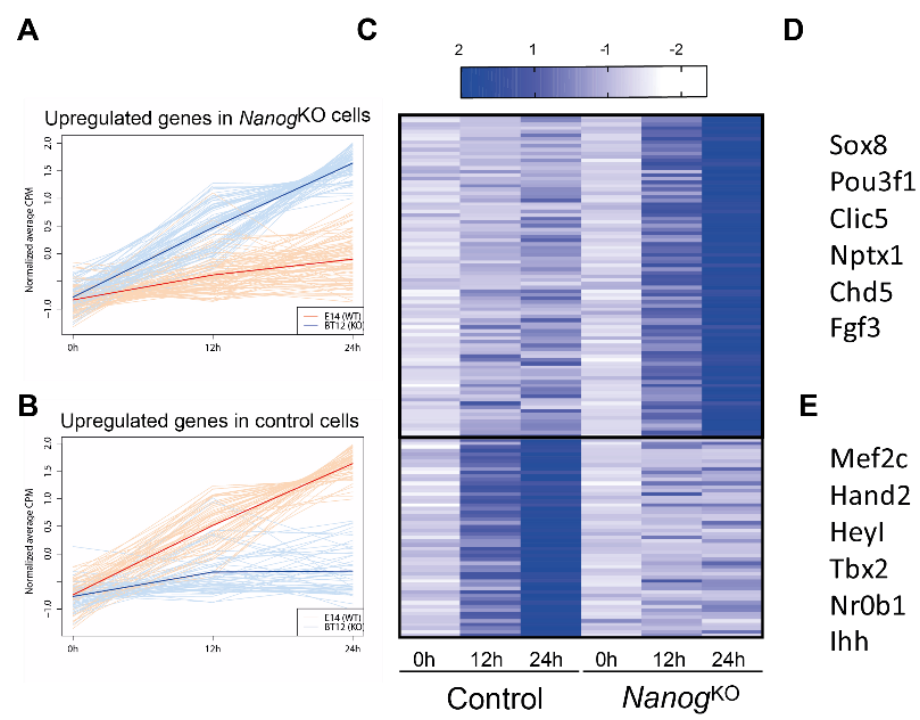

Figure 38. RNAseq analysis of the differences between control and Nanog $^{K O}$ cells across time: (A) Genes upregulated in Nanog ${ }^{K O}$ across time. (B) Genes upregulated in control across time. Blue lines represent Nanog ${ }^{K O}$ ES cells, red lines represent control cells. Thicker lines represent the mean of normalized average CPM of said genes. (C) Heatmap comparing both set of genes. (D) Representative genes of the (A) set of genes. (E) Representative genes of the $(B)$ set of genes.

When we examine genes downregulated in one condition (controls of mutants) that do not change in the other, we do not find any relevant set of genes. Only 13 genes are downregulated in the $\mathrm{Nanog}^{\mathrm{KO}}$ and do not change in controls, and vice versa 15 genes downregulated in the control do not change expression in Nanog ${ }^{K O}$ cells (Fig 39).

This analysis indicates that Nanog is involved in repression of anterior genes while promoting posterior fates, what suggests that Nanog might be important for the establishment of the anterior-posterior axis of the embryo at the exit of pluripotency. 

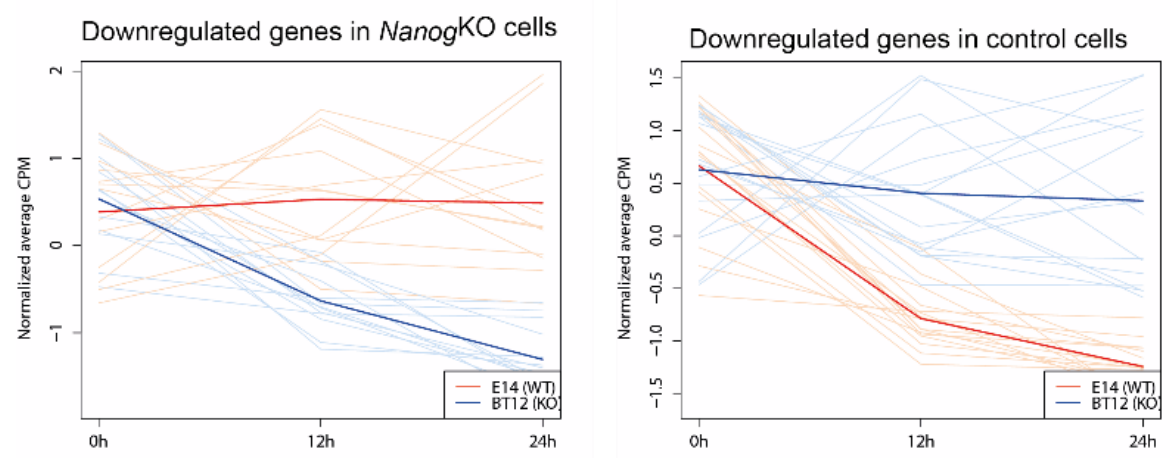

Figure 39. Set of genes downregulated for either $\operatorname{Nanog}^{K O}$ or control cells across time: Blue lines represent Nanog ${ }^{K O}$ ES cells, red lines represent control cells. Thicker lines are the mean.

\subsection{Integration of different RNA-seq data reveals Pou3f1 as a primary target for repression by NANOG in gastrulating mouse embryos}

To more specifically address the putative role of Nanog in the post-implantation epiblast, we again took advantage of published E6.5 embryo single-cell RNA-seq datasets (Mohammed et al., 2017b; Scialdone et al., 2016).

A

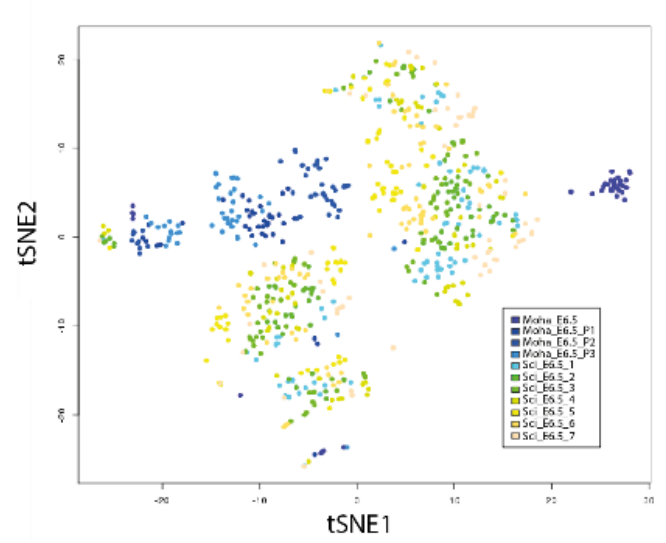

B

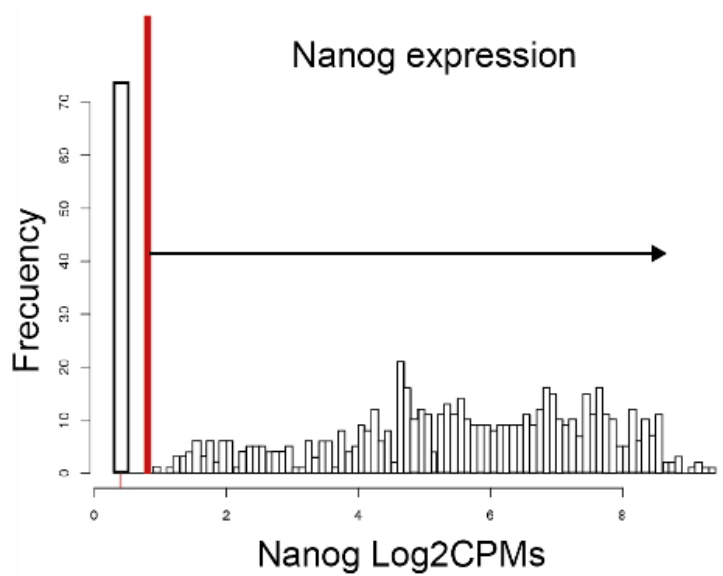

Figure 40. Representation of cells from the different experiments and their Nanog levels: (A) tSNE of all the experiments coming from two different datasets: Moha (Mohammed et al., 2017a) and Sci (Scialdone et al., 2016). Cells from each experiment are represented in different colours according to the legend. (B) Levels of expression of Nanog in Log2 counts per million. Red bar and black arrow represent the point from which we start counting cells expressing Nanog.

In this case we used two different E6.5 datasets given that we want to look at the earlier process of axis formation, and merging these datasets would help to give robustness to our analysis. This is the stage at which Nanog is re-expressed in 
the posterior part of the embryo (Hart et al., 2004b), and anterior genes such as Sox2 already show a restricted expression pattern in the epiblast. We merged both expression datasets (Fig 40) and selected those single cells expressing Nanog above a certain threshold (see Methods).

A

B
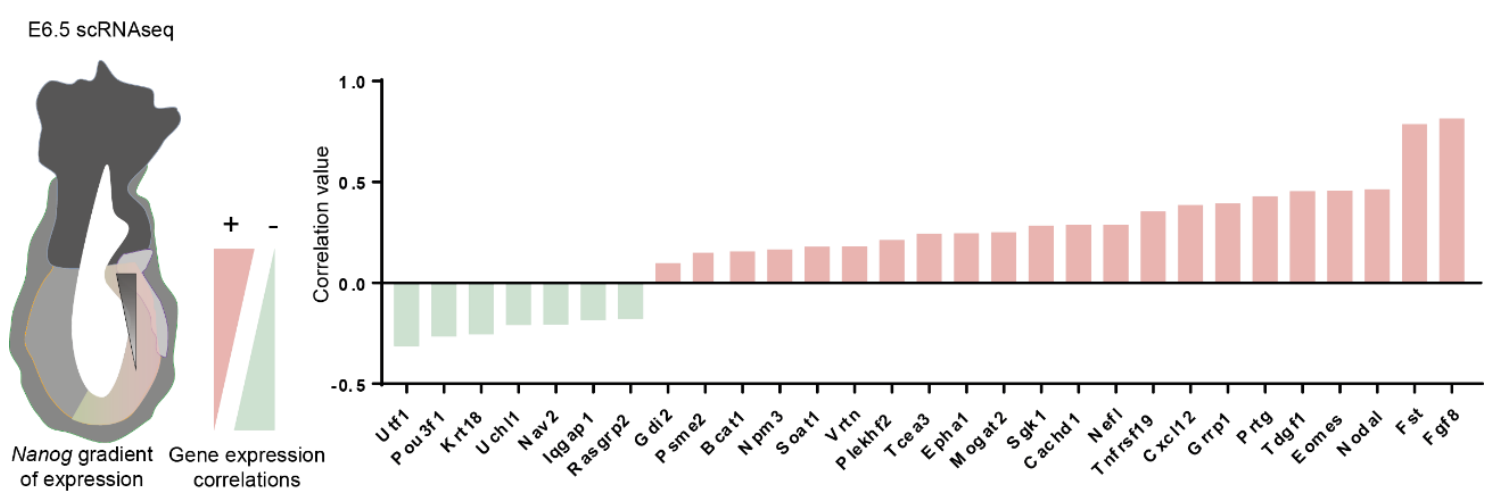

Figure 41. Correlation between Nanog and all the other genes expressed: (A) Schematic representation of an E6.5 embryo. Light red indicates Nanog's expression pattern. Black triangle on the embryo explains the diminishing levels of Nanog towards the distal region of the embryo. Red and green triangles represent the positive (red) and negative (green) correlations between Nanog and any other given gene. (B) Correlation values of the genes that show highest statistical correlation (negative in green and positive in red).

We then established the correlation of all expressed genes to Nanog (Fig 41; Table S2). The analysis of those genes whose expression in single cells showed the highest statistical correlation (both positive and negative) with the expression of Nanog confirmed our previous observations on cultured cells. Genes that correlate positively with Nanog are related with gastrulation and mesoderm formation, such as Fgf8 (Fig 42A), Nodal or Eomes (Fig 41B). On the other hand, among the genes that correlate negatively with Nanog we found Pou3f1 (Fig 42B) together with other neural genes such as Nav2 (Fig 41B). Unexpectedly, Sox2 did not show any correlation with Nanog levels (Fig 42C). Interestingly, in this group we also find Utf1, a pluripotency associated gene that during gastrulation is restricted to the anterior region of the embryo and to extraembryonic tissues (Okuda et al., 1998). Hematopoietic genes did not come up in this analysis, most possibly due to the merged data set we used, and that these genes are not expressed in the epiblast of E6.5 embryos.

We induced Nanog by administering dox to pregnant females in the drinking water from E4.5 to E7.5 Nanog ${ }^{\text {tg }}$ embryos and examined changes in gene expression by RNA-seq as compared to controls of the same genotype but that 
had not been treated with dox (Lopez-Jimenez et al.). In this dataset, many genes involved in early aspects of embryo pattering were downregulated, such as Hox genes, but the most downregulated gene was Pou3f1 (Fig 43). Moreover, we found important hematopoietic genes downregulated in this RNAseq such as Tal1 or Klf1, confirming our previous observations. Other anterior neural genes, as for example Sox2, Hesx1 or Zic3, were not changed. We confirmed these observations by whole mount in situ hybridization on E7.5 embryos from the Nanogtg line treated or not treated with dox. Induction of Nanog led to a downregulation of Pou3f1 in the anterior epiblast of treated embryos, while expression of Sox2 was unchanged (Fig 44). Interestingly, this effect was limited to early stages, as treatment up to E8.5 increases the expression of both Pou3f1 and Sox2 in the anterior neural tube (Fig 44). 
A
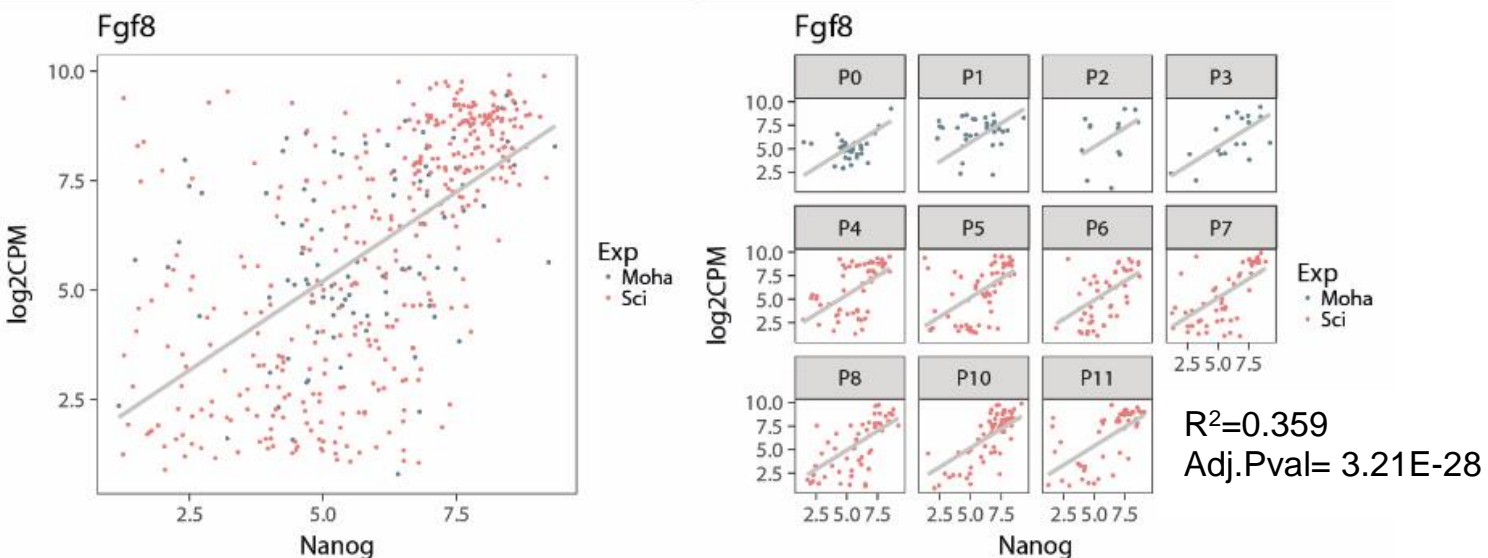

B
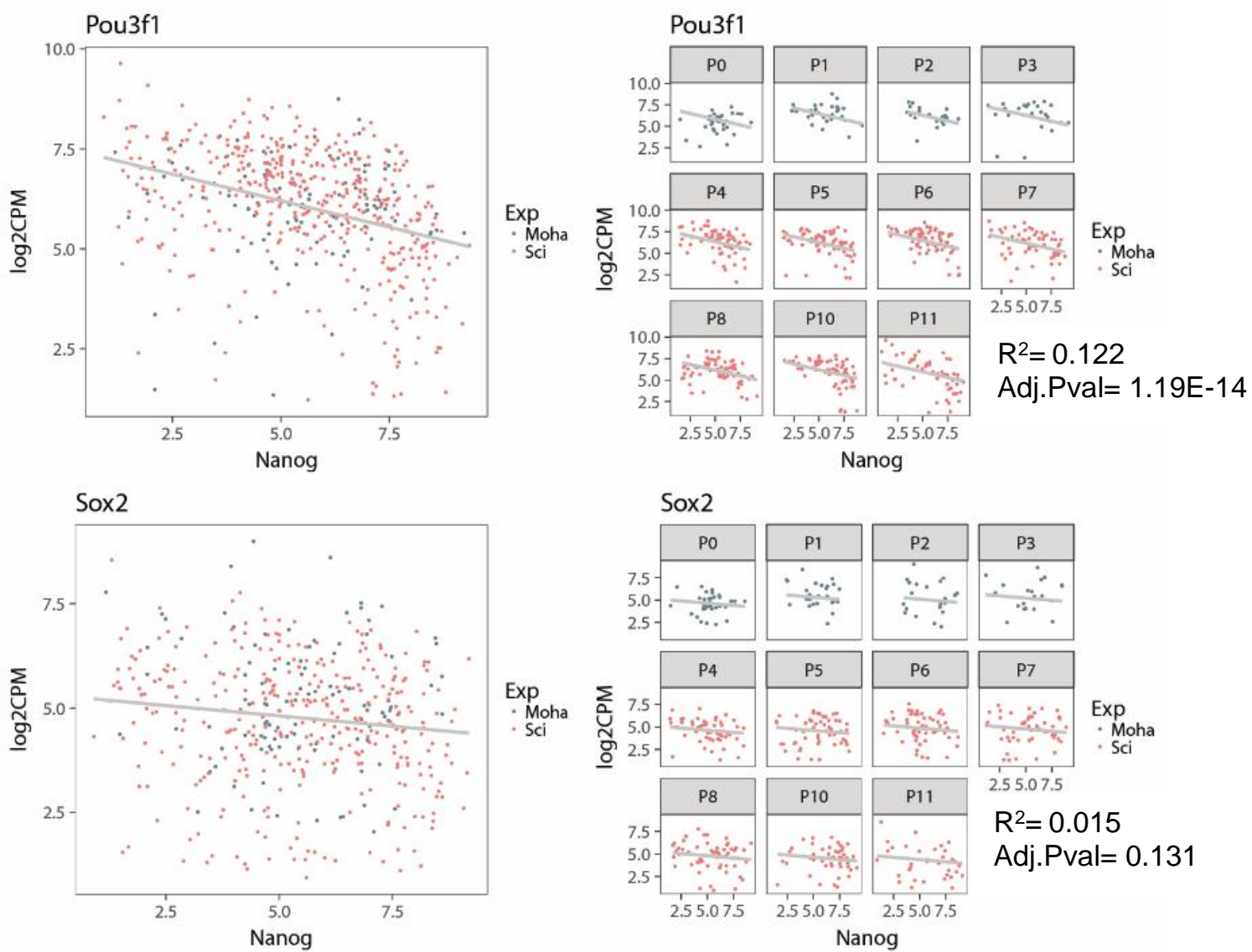

Figure 42. Graphic representation of examples of the correlations with Nanog on mixed scRNAseq experiments: On the left we find all the cells that express both Nanog and the interrogated gene. On the right correlation with Nanog of each experiment separately. Red cells come from Scialdone experiments (Scialdone et al., 2016) and blue cells come from Mohammed experiments (Mohammed et al., 2017a). (A) Correlations with Fgf8. (B) Correlations with Pou3f1. (C) Correlations with Sox2. 
We then merged the data from all previous transcriptomic analysis, finding only three genes shared by those upregulated in Nanog KO ES cells in early differentiation, showing a significant negative correlation with Nanog in E6.5 single cell transcriptomics, and downregulated in E7.5 Nanog gain-of-function embryos: Pou3f1, Lrp2 and Clic6 (Fig 45). Lrp2 and Clic6 are expressed in primitive endoderm and later derivatives (Gerbe et al., 2008; Sherwood et al., 2007), lineages where Nanog has a well-defined negative regulatory role.

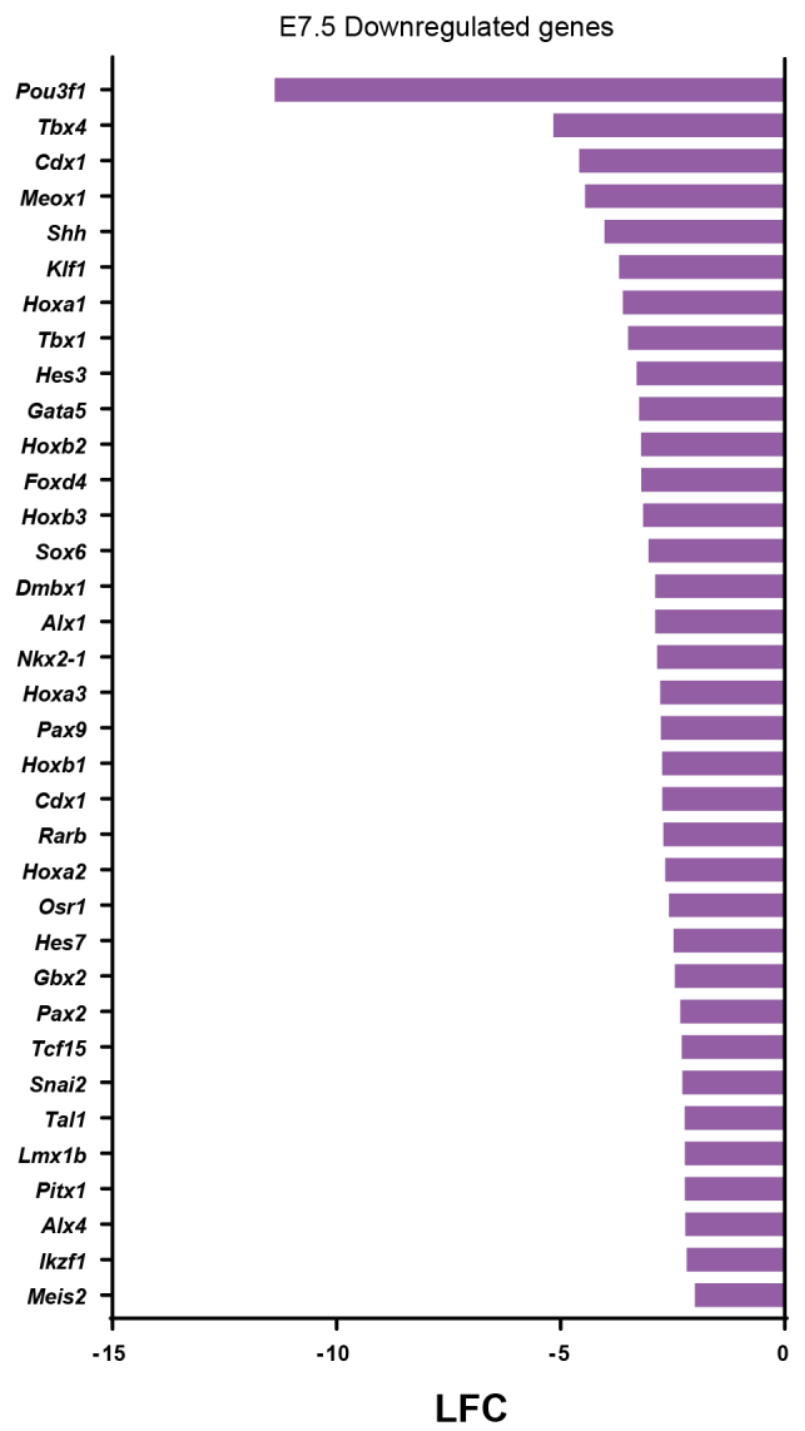

Figure 43. List of the most downregulated genes in E7.5 embryos with ectopic expression of Nanog when compared with control embryos: Bars mark the log fold change of the difference between Nanog induced and control embryos. 


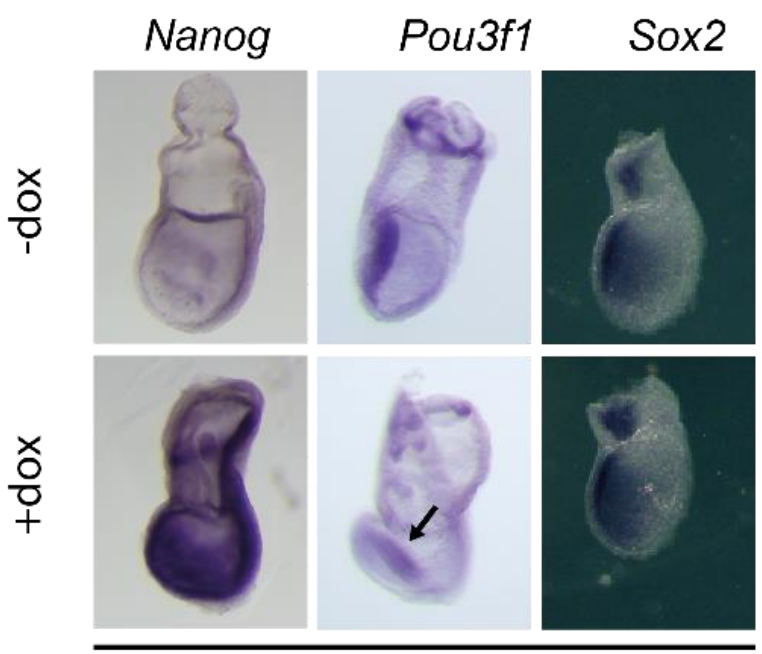

E7.5

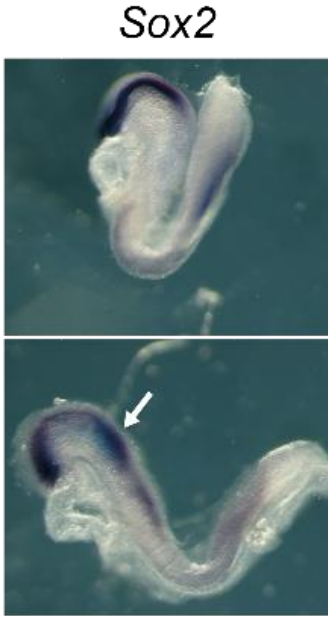

E8.5

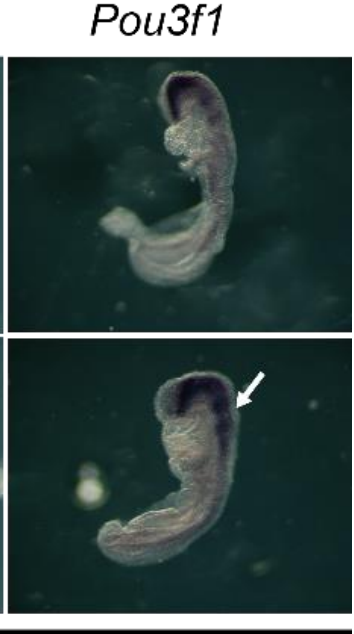

Figure 44. In situ hybridization of Nanog $^{\text {tg }}$ embryos with and without doxycycline: Black arrow means decrease in expression upon Nanog ectopic expression. White arrows increase in expression upon Nanog ectopic expression.

Therefore, Pou3f1 is the prime candidate to be a direct target of Nanog mediating its role in suppressing anterior epiblast fate. Interestingly, genes that were positively correlated with Nanog in E6.5 single cells and that were upregulated in dox-treated Nanog ${ }^{\text {tg }}$ embryos were in its majority related with early gastrulation and mesoderm specification, such as Eomes, Fgf8, Tdgf1 (Cripto) or Mixl1 (Table $5)$.

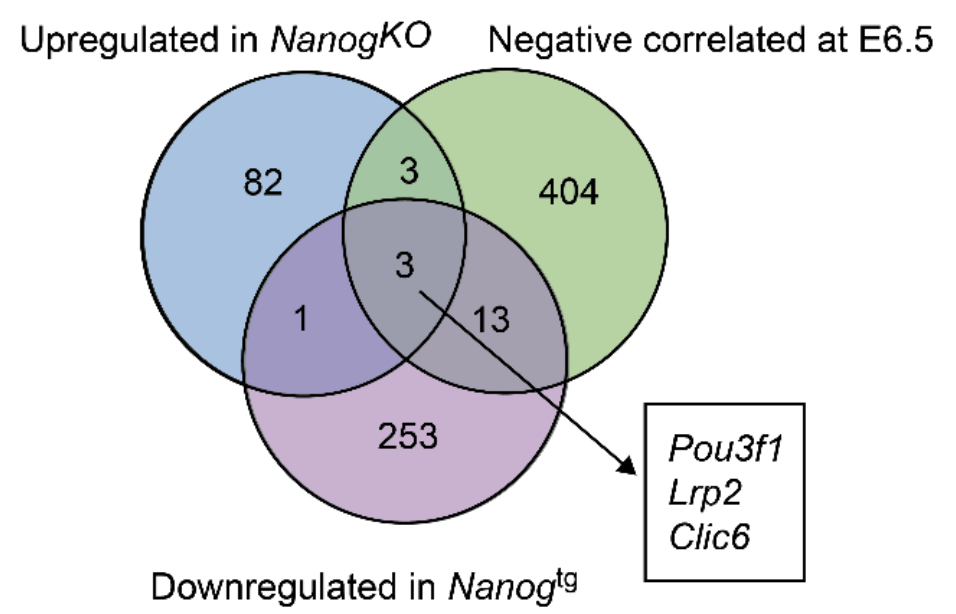

Figure 45. Venn diagram of the different RNAseq analyzed. In blue are all genes significantly upregulated upon Nanog loss of function in ES cells priming. In green genes that are negatively correlated with Nanog. In purple genes downregulated upon Nanog ectopic expression. Boxed genes are the only related to all three groups. 


\begin{tabular}{|c|c|c|c|c|c|}
\hline Intersections & total & Genes & Intersections & total & Genes \\
\hline \multirow{3}{*}{ down in 7.5 neg corr up in ko } & \multirow{3}{*}{3} & Pou3f1 & \multirow{3}{*}{ neg corr up in ko } & \multirow{3}{*}{3} & Gclm \\
\hline & & Lrp2 & & & Mt3 \\
\hline & & Clic6 & & & Dusp4 \\
\hline \multirow{3}{*}{ up in 7.5 up in ko } & \multirow{3}{*}{3} & Serpinb9f & down in 7.5 up in ko & 1 & Ctsh \\
\hline & & Serpinb9e & neg corr up in wt & 1 & Ccdc64b \\
\hline & & Rassf4 & down in 7.5 up in wt & 1 & Maf \\
\hline \multirow{9}{*}{ neg corr up in 7.5} & \multirow{9}{*}{9} & Nid1 & \multirow{16}{*}{ pos corr up in 7.5} & \multirow{16}{*}{16} & Dact1 \\
\hline & & Krt19 & & & Fes \\
\hline & & Scamp5 & & & Ahcy \\
\hline & & Tmem14c & & & Eomes \\
\hline & & Nxn & & & Nefl \\
\hline & & Skil & & & Dppa5a \\
\hline & & Enc1 & & & Tdgf1 \\
\hline & & Car2 & & & Palm \\
\hline & & Lgals1 & & & Rps2 \\
\hline \multirow{13}{*}{ down in 7.5 neg corr } & \multirow{13}{*}{13} & Rbp4 & & & Rpl21 \\
\hline & & 3110002H16Rik & & & Upp1 \\
\hline & & Crabp2 & & & Fgf8 \\
\hline & & Tmem181b-ps & & & Epha2 \\
\hline & & $\mathrm{Npl}$ & & & Mixl1 \\
\hline & & Gstm1 & & & Socs 2 \\
\hline & & Gnb4 & & & Pmepa1 \\
\hline & & Hnf4a & \multirow{5}{*}{ down in 7.5 pos corr } & \multirow{5}{*}{5} & $\mathrm{Bbx}$ \\
\hline & & SIc7a8 & & & Wls \\
\hline & & Ddah1 & & & Hmga1-rs1 \\
\hline & & $\operatorname{lgf2}$ & & & Tdh \\
\hline & & Cubn & & & Slc25a36 \\
\hline & & Cd59a & & & \\
\hline
\end{tabular}

Table 5. List of genes included in the different overlap of the venn diagram (Fig 45). Intersections columns stablish the gene sets that intersect. Total columns regard the total number of genes that intersect. Gene's columns contain the gene symbols of the gene belonging to a specific intersection.

\subsection{Nanog expression impairs neural differentiation in vitro}

To confirm that Nanog has a direct role in negatively regulating differentiation to the early neural lineage, we derived ES cells from the Nanog ${ }^{\text {tg }}$ and performed a differentiation towards anterior neural fate (Gouti et al., 2014, 2017), sampling the culture with or without dox for up to six days (Fig 46A). Analysis of gene expression by RT-qPCR showed that upon Nanog overexpression, pluripotency related genes such as Rex1 followed the same pattern in untreated or treated cells, despite a slight increase in Nanog gain-of-function cells along the time course. On the other hand, anterior neural specific genes were downregulated during the differentiation process, among them Pou3f1, Otx2 and Pax6. Sox2, 
that qualifies as both a pluripotency and early neural gene did not change (Fig 46B). Thus, upon neural differentiation, Nanog does not affect core pluripotency gene expression, but it does downregulates genes important for neural specification.

A

D3

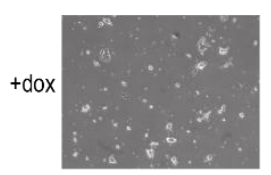

- dox

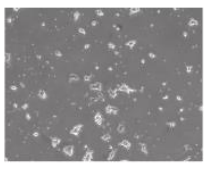

D4
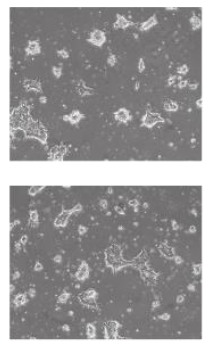

D5
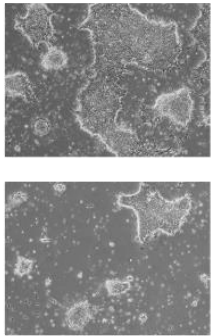

D6
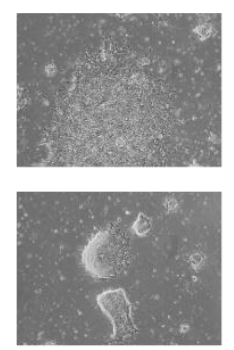

B

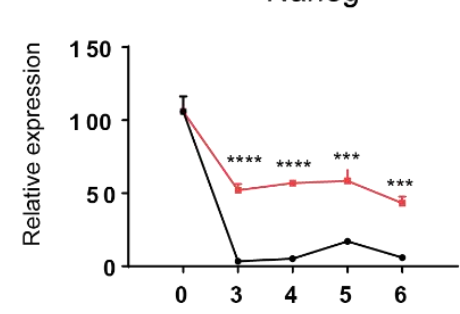

Pou3f1

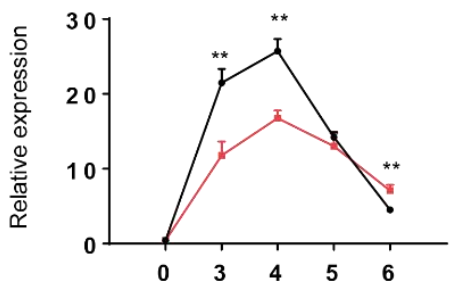

Sox2

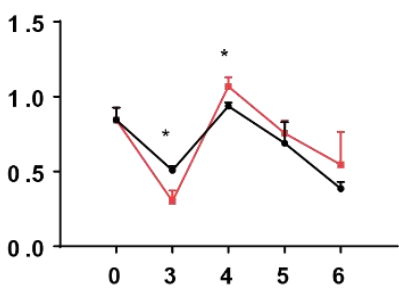

Otx2

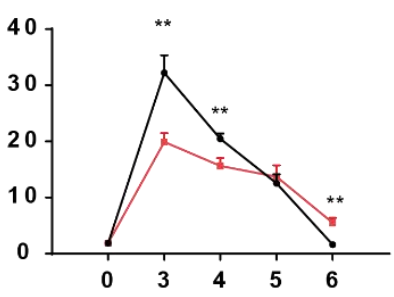

$\operatorname{Rex1}$

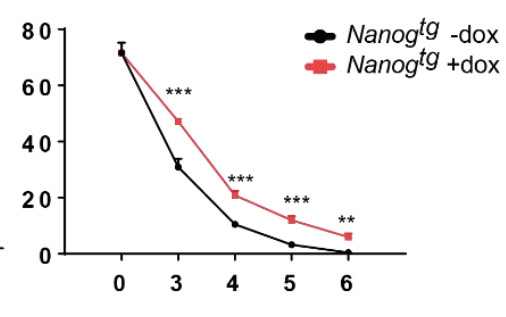

Pax6

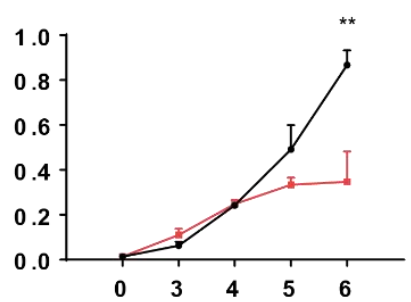

Figure 46. RT-qPCR screening of a neural differentiation of Nanog ${ }^{\text {tg }}$ ES cells. (A) Representative pictures of Nanog ${ }^{\text {tg }}$ differentiation with and without doxycycline. Pictures taken at day 3,4,5 and 6. (B) RT-qPCR of different genes with timepoints at day 0, 3, 4, 5 and 6 . In red differentiation with doxycycline. In black differentiation without doxycycline (See methods).

\subsection{A distal NANOG-binding element represses Pou3f1 expression in the posterior epiblast}

All the above evidence indicates that Pou3f1 is likely a target of NANOG during anterior-posterior axis specification in the epiblast.

Taking advantage of the already analyzed ChIP-seq data for NANOG binding in ES and epiblast-like cells (EpiLCs) (Murakami et al., 2016), we examined the 
Pou3f1 locus and identified three prominent regions of NANOG binding at 11.5 and 9.5 kilobases (kb) upstream and $9 \mathrm{~kb}$ downstream (Fig 47A). Interestingly, these regions were bound in EpiLC but not in ES cells. This is suggestive of a specific input of Nanog on Pou3f1 in the epiblast but not at earlier pluripotent stages (Fig 47A).

A

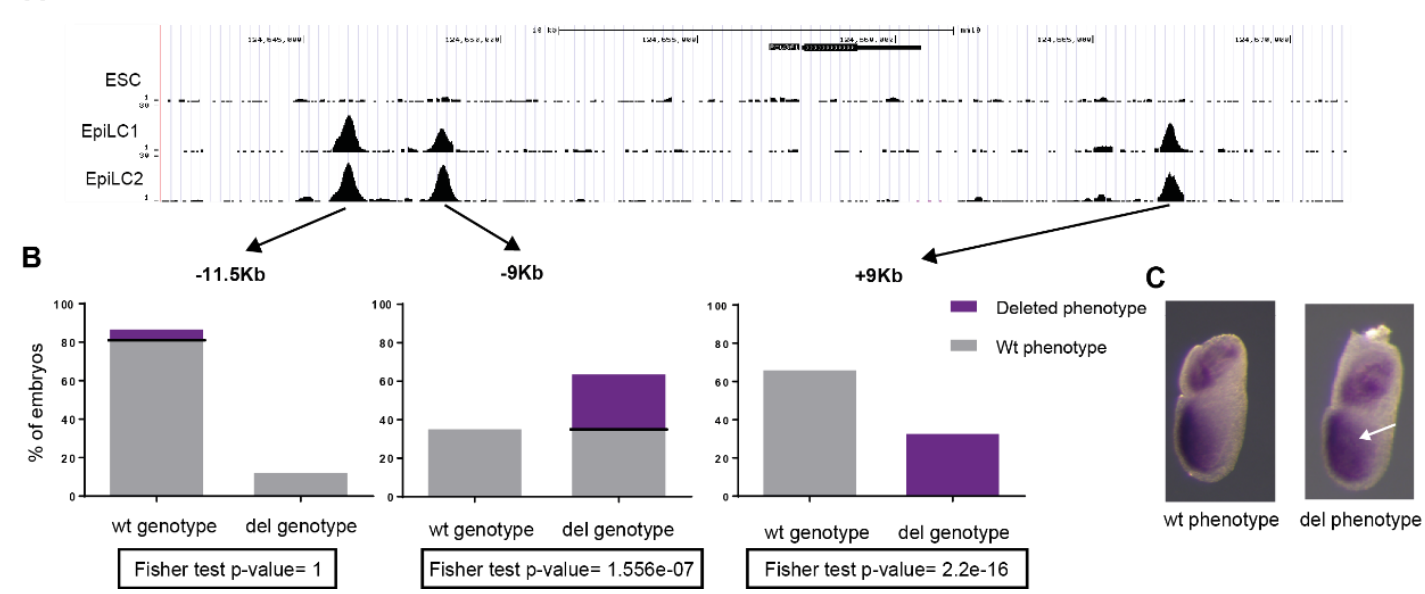

Figure 47. NANOG-BS deletion in E6.5 by CRISPRCas9 injection in the zygote. (A) Locus of Pou3f1 containing three NANOG-BS in the EpiLCs but not in the ES cells. Arrows points towards (B). Graphical representation of the phenotypic observations in embryos recovered at E6.5 and displaying the fisher test $p$ value below each graph that belongs to the specific deletion. (C) In situ hybridization of E6.5 with wt phenotype and deleted (del) phenotype, this presenting and expanded pattern of expression of Pou3f1 towards the posterior region of the embryo's epiblast as indicated by the white arrow.

We deleted each of the three binding site separately by CRISPR/Cas9 genome editing in a transient transgenic embryo assay. Embryos microinjected with Cas9gRNA ribonucleoproteins were recovered at E6.5, processed for whole mount in situ hybridization, and subsequently genotyped for the projected deletion. Since our hypothesis was that deletion of the NANOG bound region would de-repress Pou3f1 expression, we looked for an expansion of the pattern of expression of Pou3f1 towards the posterior epiblast. This assay showed that only deletion of the $+9 \mathrm{~kb}$ downstream region caused a reproducible expansion in Pou3f1 expression (Fig 47B, C). Therefore, we generated a stable mouse line carrying this deletion for a more detailed analysis (Fig 48 A). Mice homozygous for the deletion were viable and fertile. This was not completely unexpected, as homozygous null Pou3f1 survive up to birth (Bermingham et al., 1996), and we have shown that the effect of Nanog on Pou3f1 is limited to early stages of 
epiblast patterning (see above). We crossed mice heterozygous and homozygous for the deletion, and compared littermates for the expression of Pou3f1 by whole mount in situ hybridization. We observed that 3 out of 5 homozygous embryos presented a phenotype of posterior expansion while none of the heterozygous embryos did so (Fig $48 \mathrm{~B}$ ). These results show that the +9 kb NANOG bound region is important for the restriction of Pou3f1 expression to the anterior epiblast.

A GGGGTCACCAAATGGATCATTTGTCACCTTGGACCTCAAACTAGGA
AGTAACCATTCCTCCATTCACTTATCCATCAGTCCGTCTCCAGCC
AGCTACTCCTCCATTCACCGAGCCACCCACCTTTCATGCAGCCAT
TCACCTACCTACCTATTCAGCTACCCACCCATCATCTGCCATCCAT
TCATCCGATCTTCTTGCTTAACGAATTCAAGAAGCTGATGGCCT
CTAACCTCCACGCTCTTCTAGCTTTGTCTCATTCCCTTCCTGCCCC
TCAGCCATATAGGGTGTTGAGAAAACGTGTAGAAGGTAAGATG
AAACCTGTTGTCATATCTACGAAGTTGTGTAGTCCAAGTGCTGGA
B

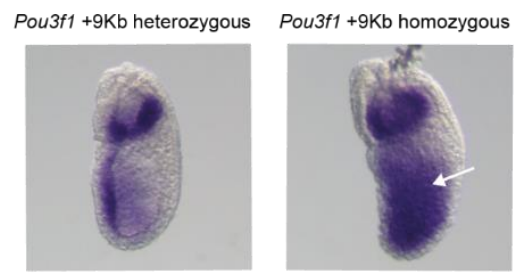
DELETED SEQUENCE GUIDE RNA

Figure 48. Representative in situ hybridization of Pou3f1 showing the differences between heterozygous and homozygous E6.5 embryos for the deletion of Pou3f1. (A) Sequence of the deleted locus. In purple the gRNAs, in grey deleted region and in black NANOG binding site. (B) Pou3f1 ISH. White arrows show the expansion of the expression pattern of Pou3f1 towards the posterior region of the embryo in the embryo homozygous for the deletion.

Taken all together, we can conclude that Nanog repress Pou3f1 when it is expressed ectopically in the whole epiblast at the onset of gastrulation. Physiologically we observe the same trend by reanalysis of scRNAseq. This not only happens in the whole embryo, but also during directed differentiation towards neural fates where we see a downregulation of anterior genes upon Nanog induction such as Otx2 and Pou3f1. In addition, deletion of one out of three different NANOG bound regions in the Pou3f1 locus is enough to expand the expression pattern of Pou3f1 to the posterior region of the epiblast of the embryo. In all, with this thesis we have demonstrated that Nanog is not only necessary for embryonic pluripotency or PGCs formation, but it also plays a fundamental role in tissue differentiation during early postimplantation development, blocking red blood cell fate during mesodermal fate choices, and restricting anterior gene programs in the epiblast of the gastrulating embryo. 



\section{DISCUSSION}





\section{DISCUSSION}

\section{A matter of disentanglement}

The pluripotency gene regulatory network (GRN) in ES cells and in the inner cell mass of the blastocyst is crucial for the activation and maintenance of pluripotency (Fig 6). However, this GRN is not only important at these stages, but also at the exit of pluripotency, in which it acquires different roles during differentiation (Iwafuchi-Doi et al., 2012). Upon implantation, changes in chromatin and in the transcriptional and epigenetic landscape make the core of this GRN formed by SOX2-OCT4-NANOG interactions change. While Oct4 is still expressed in the whole epiblast, Sox2 becomes restricted to the anterior epiblast and Nanog to the posterior epiblast (Fig 7). The entanglement between these TFs that was previously crucial in pluripotency, is finally untying to allow for tissue specification. This event change the way these TFs were interacting with each other and force them to interact with different partners. While Sox2, activated by OCT4 and POU3F1, is expressed in anterior (Iwafuchi-Doi et al., 2011b), Nanog is activated in posterior regions by SMAD2/3 and OCT4 (Sun et al., 2014). In the anterior epiblast SOX2 activates neural differentiation, and NANOG triggers mesoderm induction in the posterior epiblast (Mendjan et al., 2014; Wang et al., 2012). Actually, one of the first cells to differentiate, the primordial germ cells (PGC), express all three core pluripotency TFs, but during PGC specification, Sox2 and Nanog show contrasting roles. Nanog induces PGC-like cells while Sox2 represses them (Murakami et al., 2016). Our results further reveal a role for pluripotency factors at post-implantation stages, as we show that Nanog has a repressive role in the posterior epiblast of the gastrulating embryo. We also demonstrate that Nanog is able to block red blood cell lineage differentiation in a cell autonomous manner and that Nanog might directly suppress Tal1 in the gastrulating embryo. Likewise, we have described how Nanog is able to repress Pou3f1 in the posterior embryo without affecting Sox2 expression, which opens the way to a broader GRN for the establishment of the anteroposterior axis of the epiblast. 


\section{Nanog in pluripotency and beyond}

The pluripotent potential of stem cell relies on the gene pluripotency network placed around Oct4, Sox2 and Nanog (Navarro et al., 2012; Tay et al., 2008; Trott and Martinez Arias, 2013). Up to date, there are two different and well defined steady state stages of pluripotency that have been termed naïve and primed. They have been extensively described in vitro and have clear transcriptional and epigenetic differences (Joo et al., 2014; Nichols and Smith, 2009b). The main functional difference is that the primed state cannot give rise to blastocyst chimeras. Beyond that, both can be maintained in vitro: with LIF and $2 \mathrm{i}$ for the naïve state and with Activin and FGF for primed ES cells (Tesar et al., 2007). These two states can be interconverted in vitro although reprogramming towards pluripotency comprise a much complex and costly process than differentiation (Festuccia et al., 2013).

Overexpression of Nanog in ES cells make them able to self-renew without LIF, BMP or 2i (Chambers et al., 2003; Hall et al., 2009; Ying et al., 2003). Although Nanog is essential for epiblast formation in the preimplantation embryo (Mitsui et al., 2003b) it can be deleted in ES cells that maintain their pluripotency, although they are more prone to differentiate (Chambers et al., 2007a). Therefore, it has been well established that Nanog is important for pluripotency maintenance both in vitro and in vivo. Yet little is known about the role of Nanog at the exit of pluripotency.

\section{Exit of pluripotency and embryo axis formation}

Although most of the axis formation experiments have been performed in vivo (Arnold and Robertson, 2009; Beddington and Robertson, 1999; Hiramatsu et al., 2013), ES cells allow us to study this process in vitro (Deglincerti et al., 2016; Morgani et al., 2018; Stryjewska et al., 2017). In the postimplantation embryo, anterior-posterior patterning is one of the first differentiation events to occur. At this stage both anterior -such as Otx2 and Pou3f1- and posterior genes -like Zeb2 or Brachyury- are upregulated. Due to the parallelisms between naïve ES cells and pluripotent epiblast, and between primed ES cells and the postimplantation epiblast, it is expected that in the first stages of differentiation in 
ES cells we would have upregulation of these anterior and posterior markers. (Acampora et al., 2016; Buecker et al., 2014; Stryjewska et al., 2017).

In this thesis, we wanted to capture the first steps in the priming of naïve ESC so that we could assess the role of Nanog in early pluripotency exit. With this aim in mind, we maintained Nanog ${ }^{K O}$ ES cells in naïve conditions to later culture them in a permissive medium for differentiation and look closely at the very first step of differentiation, just 24 hours (Fig 35).

Accordingly, from our Nanog ${ }^{K O}$ experiments in ES cell priming we have been able to interrogate what is the role of Nanog in promoting such first stages of differentiation. We observed that Nanog was repressing anterior fate while promoting posterior differentiation. As pluripotent cells transit towards a primed state, it is obvious that the absence of Nanog will generate an imbalance in the lineage fate of the cells, that reflects the equilibrium in which Nanog, Oct4 and Sox2 are in this state transition (Pfeuty et al., 2018). We could expect that in the absence of Nanog, Sox2 would drive the cells towards a more anterior fate. Also it has been recently shown that Nanog antagonizes the anterior gene Otx2 in vitro (Acampora et al., 2017). However in this thesis we have stablished that another anterior gene more consistently regulated by Nanog is Pou3f1, both in vitro as well as in vivo.

Pou3f1 has been identified as an activator of Sox2 in vivo and in vitro through the N2 enhancer (Iwafuchi-Doi et al., 2011b; Zhu et al., 2014). Pou3f1 is expressed in the ExE and the anterior epiblast (Zwart et al., 1996). It is expressed at E5.5 (when Nanog is switched off) in the mouse epiblast and at E6.5 its expression is restricted to the anterior epiblast. In later embryos its expression restricts to a more anterior position (Zhu et al., 2014; Zwart et al., 1996). This localization to the anterior epiblast coincides with the start of the re-expression of Nanog (Hoffman et al., 2013b). Additionally, when we deleted a specific NANOG bound site in the locus of Pou3f1, this gene starts expressing in the posterior region of the embryo.

Therefore Pou3f1 is not just a marker of the exit of pluripotency upregulated when Nanog is downregulated (Acampora et al., 2016), but instead a direct target that is repressed by Nanog during embryo differentiation. This not only occurs in the 
first stage of differentiation, as when we differentiate the cells towards anterior neural fate we also observe a downregulation of Pou3f1 upon Nanog activation in vitro (Fig 46). A question that emerge from our experiments and the pattern of expression of both genes is whether physiological disappearance of Nanog expression at E5.5 is important for Pou3f1 de novo expression in the epiblast at that same stage (Festuccia et al., 2013).

\section{Anteriorization of the embryo: causes and consequences}

We have generated a mouse line with a deletion in the locus of Pou3f1, 9Kb downstream of the transcription start site, that correspond to a NANOG bound region as detected by ChIP-seq (Murakami et al., 2016). This bound region of NANOG is only present in EpiLCs, which indicates a shift in the GRN that accompanies NANOG in this cell state similar to the postimplantation/pregastrulation epiblast (Hayashi et al., 2011). The phenotype we observe is a posteriorization of the expression of Pou3f1. However, this expansion in the domain of expression of Pou3f1 does not occur in all embryos analyzed, what poses some interesting questions. Does expression of Pou3f1 in the posterior epiblast anteriorizes this region? Does this jeopardize later embryo viability, or only those embryos that do not gain Pou3f1 expression make it through gastrulation? The answer to these questions will shed some light on the boundaries between anterior TFs and posterior TFs and their external inputs.

In addition, it is important to highlight that according to our results the effect of Nanog on Pou3f1 appears to be stage specific. The repression we have observed in Pou3f1 upon Nanog activation is only observed in early gastrulation stages. Later, when Nanog is no longer expressed but we activate its expression we observed an ectopic expression of Pou3f1 and of Sox2 as well, which could be triggered by the former. Understanding this change in the response of Pou3f1 to Nanog from repression to activation sure merits further investigation.

Analysis of co-expression and correlations of well studied genes in scRNAseq data is going to be crucial for answering questions on embryo patterning during gastrulation. In this thesis we have used two different data sets of E6.5 scRNAseq to correlate expression with Nanog (Mohammed et al., 2017a; Scialdone et al., 2016). As data keeps on growing, we will be able to build a denser map with 
higher resolution of the physiological interactions between different genes. This will help us understand how the pluripotency GRN is dismantled at the exit of pluripotency and how new ones come together during gastrulation.

\section{The very first red blood cell}

Moving to the other end of the embryo, red blood cell (RBC) precursors are the first cell type to be specified from nascent mesoderm during mouse gastrulation (Baron et al., 2012, Kinder et al., 1999). While the genes and networks that determine primitive hematopoietic cells are well understood (Isern et al., 2011, Kingsley et al., 2013), much less is known about how precursors are specified during the early stages of primitive streak formation (Padrón-Barthe et al., 2014). Actually, studies of scRNAseq have helped us discover some genes that are involved in this process such as Tal1 (Scialdone et al., 2016). Differentiation from epiblast to RBC occurs in a very short time frame (Padrón-Barthe et al., 2014). Hence, it is only logical to hypothesize that even before gastrulation there must be a priming of the cells that are going to migrate through the primitive streak up to the extraembryonic region where they will become RBC.

\section{Role of Nanog in mesoderm-to-RBC fate choice}

Here, we show that the pluripotency factor NANOG regulates the transition from multipotent mesodermal progenitors to red blood cell precursors in these early steps, at least partially through the direct regulation of the lineage specifier Tal1.

Our results suggest that a similar situation may occur during specification of the first mesodermal lineages. Nanog expression in Brachyury-positive cells maintains them in a pan-mesodermal multipotent state, whereas its downregulation would allow the expression of early hematopoietic lineage specifiers, driving their differentiation to primitive red blood cells. This process, however, occurs during a limited time window during the initial phases of gastrulation, as Nanog is quickly downregulated in all cells by E8.0-8.5 (Hart et al., 2004a; Scialdone et al., 2016). By this stage, mesodermal progenitors have ingressed through the primitive streak and are no longer able to activate the early hematopoietic program, a process that also involves restricted spatial signaling through the Wnt and Bmp pathways (Cheng et al., 2008; Mimoto et al., 2015; Myers and Krieg, 2013). Therefore, this Nanog-mediated switch would act to 
control the rapid specification of blood precursors, the first lineage determination event in gastrulation, and required to supply the embryo with oxygen to support its subsequent exponential growth.

\section{Early postimplantation embryo regulation of Tal1 expression}

We also show that Nanog directly represses the master hematopoietic regulator Tal1 (Porcher et al., 2017) through an upstream regulatory element located in an intron of the neighboring Stil gene. Interestingly, this site is occupied by NANOG only during the differentiation of ES cells to EpiLCs (Murakami et al., 2016). This change in binding site usage during this transition again suggests that Nanog, as it does in the locus of Pou3f1, has specific roles in the postimplantation pregastrulating epiblast (the in vivo equivalent of EpiLCs (Hayashi et al., 2011)) that are distinct from those operating during the pluripotent state. Tal1 is certainly a prime candidate for mediating the effects of Nanog on erythropoiesis, as we found that it is consistently repressed at different embryonic stages and in adult erythroid progenitors. However, we do not rule out that other genes involved in early erythroid development will be also direct Nanog targets.

\section{A new model for myelodysplasia?}

In the adult, Nanog expression leads to defective erythroid-cell maturation, as also occurs in the embryo, and to an accumulation of MEPs showing downregulation of Tal1. This can be explained by a defect in the differentiation of said progenitors, and the phenotype we observe is reminiscent of the adultspecific Tal1 knockout (Hall et al., 2005). It is therefore tempting to speculate that the regulatory circuit acting in the early embryo is reenacted in the adult solely by induction of Nanog. This could be a way of inducing a myelodysplasia in adult mice, however adult mice with global Nanog expression start dying from day 10 of treatment because of epithelial tumors and problems in the esophagus (Piazzolla et al., 2014) and therefore we would lack important data on circulating cells that last for longer times. Another way of generating this disease model would be through transplantation of bone marrow, but as we have seen in this thesis, Nanog induced MEPs are prone to disappear if any host's HSC remains, which would make it difficult to obtain consistent results. Nevertheless, the effect of Nanog in bone marrow precursors is severe. It is precisely this strong effect what could help us gain more insight in the dynamics of the different precursors 
populations, not only in relation with each other but also with hematopoietic stem cells in the context of myelodysplasia.

\section{Nanog is a physiological barrier in red blood cell differentiation}

Hematopoietic differentiation of $\mathrm{Nanog}^{-/}$ES cells (Chambers et al., 2007) confirms the proposed role for Nanog in erythroid development. Although Nanog/ cells show an initial delay in the activation of early pan-mesodermal markers such as Brachyury, once this occurs they show a faster and more coherent expression of erythroid genes. Directed differentiation reveals that the lack of Nanog promotes the red blood cell potential of these cells, which show a marked increase in both primitive and more mature erythroid colony formation. Our results show that Nanog acts as a barrier to red blood cell development. Controlled downregulation of Nanog during the initial phases of differentiation may present a novel approach to boosting the generation of red blood cells from pluripotent stem cells, a major clinical need (Kaufman, 2009).

\section{Nanog: a Swiss knife for lineage specification during gastrulation}

Along gastrulation, numerous differentiation processes must take place in an orderly and controlled manner. Upon the formation of the primitive streak epiblast cells will give rise to mesoderm, endoderm and ectoderm (Tam and Behringer, 1997). At this stage, epiblast cells also differentiate towards PGCs. The crucial role of Nanog in PGCs differentiation and migration has been studied in detail (Murakami et al., 2016; Sánchez-Sánchez et al., 2010), although recent work has demonstrated that Nanog can be replaced completely by Esrrb (Zhang et al., 2018). Through the work presented in this thesis, we suggest two novel roles for Nanog: blocking anterior fate through Pou3f1, and red blood cell differentiation through Tal1. Thus, we propose that the transcription factor NANOG acquires different functionalities after implantation that were not previously related with each other. It is yet to determine how has Nanog gained these properties throughout evolution and how Nanog regulation works at the onset of gastrulation. Further understanding of the epigenetic variations at these stages, as well as the changes in partners and target genes of NANOG, as well as SOX2 or OCT4, will broaden our understanding of how a pluripotent cell is able to jump into the void of differentiation. 


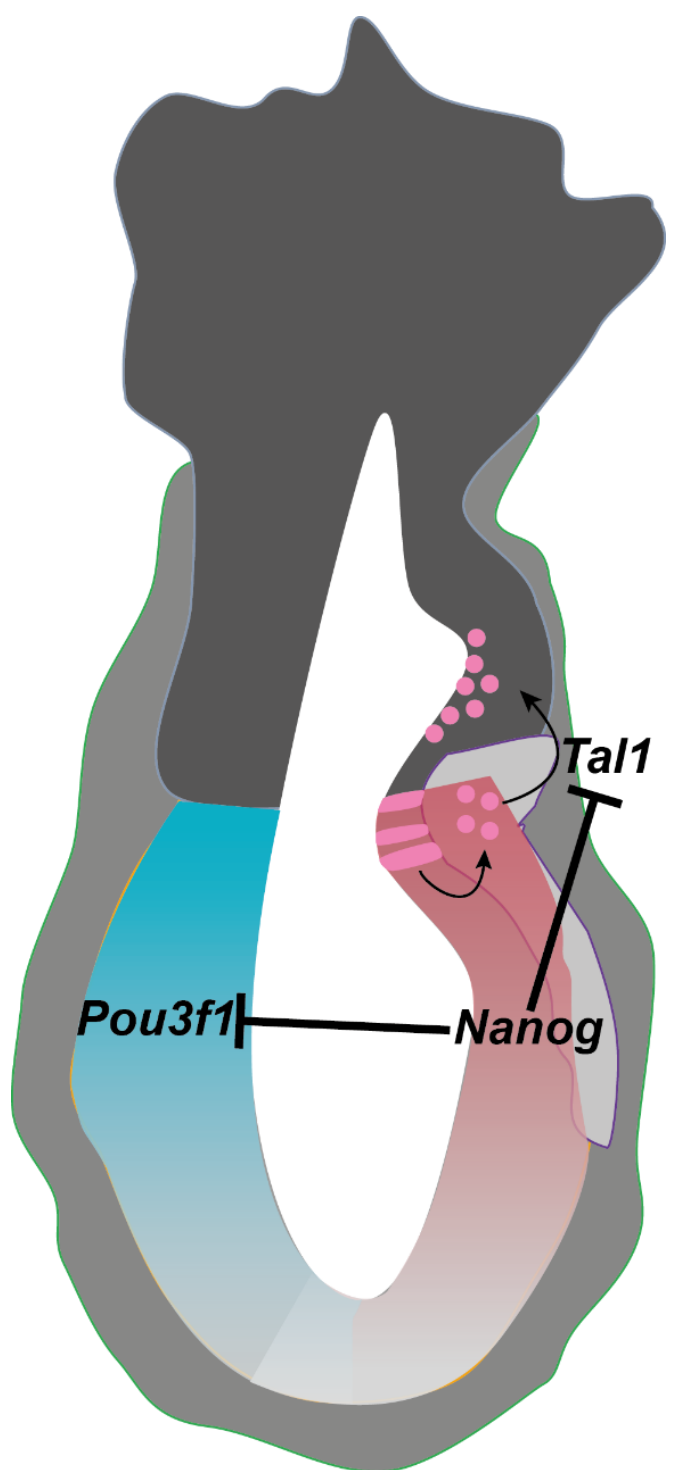

Figure 49. Nanog repress Tal1 in red blood cell specification and Pou3f1 during anteriorization of the epiblast. Representation of an E6.5 mouse embryo. The expression domain of Nanog is indicated in red, and that of Pou3f1 in blue. Pink cells are lineage fated red blood cells. Blunt arrows indicate repression. Arrows indicate direction of differentiation and migration. 
CONCLUSIONS 



\section{CONCLUSIONS}

1. Nanog blocks erythroid differentiation in the embryo at gastrulation stages in a cell autonomous manner.

2. Loss of function of Nanog in embryonic stem cells leads to increased differentiation potential towards erythroblast progenitors.

3. Gain-of-function of Nanog in the adult bone marrow leads to blockade of erythroid differentiation, closely resembling the early embryonic hematopoietic phenotype.

4. Tal1 is a direct transcriptional target of NANOG during gastrulation.

5. Loss of function of Nanog during the exit of naïve pluripotency and in the transit to the primed state leads to the upregulation of anterior-neural genes.

6. Nanog inhibits neural specification in the early embryo and in vitro.

7. Nanog directly repress Pou3f1 in the posterior epiblast of the gastrulating embryo. 



\section{CONCLUSIONES}

1. Nanog bloquea la diferenciación eritroide durante la gastrulación de forma autónoma.

2. La pérdida de función de Nanog en células madre embrionarias conlleva un incremento del potencial de diferenciación de estas células a progenitores eritrocíticos

3. La ganancia de función de Nanog en médula ósea adulta comporta un bloqueo de la diferenciación eritrocítica, muy parecido al fenotipo observado en la hematopoiesis embrionaria.

4. Tal1 es una diana transcripcional directo de NANOG durante la gastrulación del embrión.

5. La falta de función de Nanog durante la salida de la pluripotencia naïve y en la transición hacia un estado preparado para la diferenciación propicia un aumento en la expresión de genes relacionados con linaje anterior-neural.

6. Nanog inhibe la especificación neural en el embrión temprano e in vitro.

7. Nanog reprime directamente Pou3f1 en la región posterior del embrión durante la gastrulación. 



\section{BIBLIOGRAPHY}





\section{BIBLIOGRAPHY}

Abranches, E., Bekman, E., and Henrique, D. (2013). Generation and Characterization of a Novel Mouse Embryonic Stem Cell Line with a Dynamic Reporter of Nanog Expression. PLoS One 8, e59928.

Acampora, D., Omodei, D., Petrosino, G., Garofalo, A., Savarese, M., Nigro, V., Di Giovannantonio, L.G., Mercadante, V., and Simeone, A. (2016). Loss of the Otx2-Binding Site in the Nanog Promoter Affects the Integrity of Embryonic Stem Cell Subtypes and Specification of Inner Cell Mass-Derived Epiblast. Cell Rep. 15, 2651-2664.

Acampora, D., Di Giovannantonio, L.G., Garofalo, A., Nigro, V., Omodei, D., Lombardi, A., Zhang, J., Chambers, I., and Simeone, A. (2017). Functional Antagonism between OTX2 and NANOG Specifies a Spectrum of Heterogeneous Identities in Embryonic Stem Cells. Stem Cell Reports 9, 1642-1659.

Acloque, H., Ocaña, O.H., Matheu, A., Rizzoti, K., Wise, C., Lovell-Badge, R., and Nieto, M.A. (2011). Reciprocal Repression between Sox3 and Snail Transcription Factors Defines Embryonic Territories at Gastrulation. Dev. Cell $21,546-558$.

Aksoy, I., Jauch, R., Chen, J., Dyla, M., Divakar, U., Bogu, G.K., Teo, R., Leng $\mathrm{Ng}$, C.K., Herath, W., Lili, S., et al. (2013). Oct4 switches partnering from Sox2 to Sox17 to reinterpret the enhancer code and specify endoderm. EMBO J. 32 , 938-953.

Alvarez-Dominguez, J.R., Hu, W., Yuan, B., Shi, J., Park, S.S., Gromatzky, A.A., Oudenaarden, A. v., and Lodish, H.F. (2014). Global discovery of erythroid long noncoding RNAs reveals novel regulators of red cell maturation. Blood 123, 570-581.

Aplin, J.D., and Ruane, P.T. (2017). Embryo-epithelium interactions during implantation at a glance. J. Cell Sci. 130 .

Arnold, S.J., and Robertson, E.J. (2009). Making a commitment: cell lineage allocation and axis patterning in the early mouse embryo. Nat. Rev. Mol. Cell 
Biol. 10, 91-103.

Avilion, A., Nicolis, S., Pevny, L., Perez, L., and Vivian, N. (2003). Multipotent cell lineages in early mouse development depend on SOX2 function. Genes Dev 17.

Baedke, J. (2013). The epigenetic landscape in the course of time: Conrad Hal Waddington's methodological impact on the life sciences. Stud. Hist. Philos. Sci. Part C Stud. Hist. Philos. Biol. Biomed. Sci. 44, 756-773.

Baron, M.H., Isern, J., and Fraser, S.T. (2012). The embryonic origins of erythropoiesis in mammals. Blood 119, 4828-4837.

Beck, S., Le Good, J.A., Guzman, M., Haim, N. Ben, Roy, K., Beermann, F., and Constam, D.B. (2002a). Extraembryonic proteases regulate Nodal signalling during gastrulation. Nat. Cell Biol. 4, 981-985.

Beck, S., Le Good, J.A., Guzman, M., Haim, N. Ben, Roy, K., Beermann, F., and Constam, D.B. (2002b). Extraembryonic proteases regulate Nodal signalling during gastrulation. Nat. Cell Biol. 4, 981-985.

Beddington, R.S.., and Robertson, E.J. (1999). Axis Development and Early Asymmetry in Mammals. Cell 96, 195-209.

Bell, K.M., Western, P.S., and Sinclair, A.H. (2000). SOX8 expression during chick embryogenesis. Mech. Dev. 94, 257-260.

Bermingham, J.R., Scherer, S.S., O'Connell, S., Arroyo, E., Kalla, K.A., Powell, F.L., and Rosenfeld, M.G. (1996). Tst-1/Oct-6/SCIP regulates a unique step in peripheral myelination and is required for normal respiration. Genes Dev. 10, 1751-1762.

Borges, L., lacovino, M., Mayerhofer, T., Koyano-Nakagawa, N., Baik, J., Garry, D.J., Kyba, M., Letarte, M., and Perlingeiro, R.C.R. (2012). A critical role for endoglin in the emergence of blood during embryonic development. Blood 119, 5417-5428.

Boroviak, T., and Nichols, J. (2014). The birth of embryonic pluripotency. Philos. Trans. R. Soc. 369, 20130541. 
de Bruijn, M.F., Speck, N.A., Peeters, M.C., and Dzierzak, E. (2000). Definitive hematopoietic stem cells first develop within the major arterial regions of the mouse embryo. EMBO J. 19, 2465-2474.

Buecker, C., Srinivasan, R., Wu, Z., Calo, E., Acampora, D., Faial, T., Simeone, A., Tan, M., Swigut, T., and Wysocka, J. (2014). Reorganization of Enhancer Patterns in Transition from Naive to Primed Pluripotency. Cell Stem Cell 14, 838-853.

Bylund, M., Andersson, E., Novitch, B.G., and Muhr, J. (2003). Vertebrate neurogenesis is counteracted by Sox1-3 activity. Nat. Neurosci. 6, 1162-1168.

Calkins, G.N. (1908). THE SO-CALLED RHYTHMS OF GROWTH-ENERGY IN MOUSE CANCER. J. Exp. Med. 10, 283-307.

Challen, G.A., Boles, N., Lin, K.-Y.K., and Goodell, M.A. (2009). Mouse hematopoietic stem cell identification and analysis. Cytom. Part A 75A, 14-24.

Chambers, I., and Tomlinson, S.R. (2009). The transcriptional foundation of pluripotency. Development 136, 2311-2322.

Chambers, I., Colby, D., Robertson, M., Nichols, J., Lee, S., Tweedie, S., and Smith, A. (2003). Functional expression cloning of Nanog, a pluripotency sustaining factor in embryonic stem cells. Cell 113, 643-655.

Chambers, I., Silva, J., Colby, D., Nichols, J., Nijmeijer, B., Robertson, M., Vrana, J., Jones, K., Grotewold, L., and Smith, A. (2007a). Nanog safeguards pluripotency and mediates germline development. Nature 450, 1230-1234.

Chambers, I., Silva, J., Colby, D., Nichols, J., Nijmeijer, B., Robertson, M., Vrana, J., Jones, K., Grotewold, L., and Smith, A. (2007b). Nanog safeguards pluripotency and mediates germline development. Nature 450, 1230-1234.

Chazaud, C., Yamanaka, Y., Pawson, T., and Rossant, J. (2006). Early lineage segregation between epiblast and primitive endoderm in mouse blastocysts through the Grb2-MAPK pathway. Dev. Cell 10,615-624.

Chen, M.J., Yokomizo, T., Zeigler, B.M., Dzierzak, E., and Speck, N.A. (2009). Runx1 is required for the endothelial to haematopoietic cell transition but not 
thereafter. Nature $457,887-891$.

Chen, X., Xu, H., Yuan, P., Fang, F., Huss, M., Vega, V.B., Wong, E., Orlov, Y.L., Zhang, W., Jiang, J., et al. (2008). Integration of external signaling pathways with the core transcriptional network in embryonic stem cells. Cell 133, 1106-1117.

Cheng, X., Huber, T.L., Chen, V.C., Gadue, P., and Keller, G.M. (2008). Numb mediates the interaction between Wnt and Notch to modulate primitive erythropoietic specification from the hemangioblast. Development 135, 34473458.

Chisholm, J.C., Johnson, M.H., Warren, P.D., Fleming, T.P., and Pickering, S.J. (1985). Developmental variability within and between mouse expanding blastocysts and their ICMs. J. Embryol. Exp. Morphol. 86, 311-336.

Conway Morris, S. (2000). The Cambrian \&quot;explosion\&quot;: slow-fuse or megatonnage? Proc. Natl. Acad. Sci. U. S. A. 97, 4426-4429.

Deglincerti, A., Etoc, F., Guerra, M.C., Martyn, I., Metzger, J., Ruzo, A., Simunovic, M., Yoney, A., Brivanlou, A.H., Siggia, E., et al. (2016). Selforganization of human embryonic stem cells on micropatterns. Nat. Protoc. 11, 2223-2232.

DeVeale, B., Brokhman, I., Mohseni, P., Babak, T., Yoon, C., Lin, A., Onishi, K., Tomilin, A., Pevny, L., Zandstra, P.W., et al. (2013). Oct4 Is Required $\sim$ E7.5 for Proliferation in the Primitive Streak. PLoS Genet. 9, e1003957.

Díaz-Díaz, C., Fernandez de Manuel, L., Jimenez-Carretero, D., Montoya, M.C., Clavería, C., and Torres, M. (2017). Pluripotency Surveillance by Myc-Driven Competitive Elimination of Differentiating Cells. Dev. Cell 42, 585-599.e4.

Doré, L.C., and Crispino, J.D. (2011). Transcription factor networks in erythroid cell and megakaryocyte development. Blood 118, 231-239.

Downs, K.M., and Davies, T. (1993). Staging of gastrulating mouse embryos by morphological landmarks in the dissecting microscope. Development 118 , 1255-1266. 
Duboule, D., and Morata, G. (1994). Colinearity and functional hierarchy among genes of the homeotic complexes. Trends Genet. 10, 358-364.

England, S.J., Blanchard, G.B., Mahadevan, L., Adams, R.J., Beuchle, D., van Eeden, F.J., Furutani-Seiki, M., Granato, M., Haffter, P., Hammerschmidt, M., et al. (2006). A dynamic fate map of the forebrain shows how vertebrate eyes form and explains two causes of cyclopia. Development 133, 4613-4617.

Fehling, H.J., Lacaud, G., Kubo, A., Kennedy, M., Robertson, S., Keller, G., and Kouskoff, V. (2003). Tracking mesoderm induction and its specification to the hemangioblast during embryonic stem cell differentiation. Development 130, 4217-4227.

Feldman, B., Poueymirou, W., Papaioannou, V.E., DeChiara, T.M., and Goldfarb, M. (1995). Requirement of FGF-4 for postimplantation mouse development. Science 267, 246-249.

Ferri, A., Favaro, R., Beccari, L., Bertolini, J., Mercurio, S., Nieto-Lopez, F., Verzeroli, C., La Regina, F., De Pietri Tonelli, D., Ottolenghi, S., et al. (2013). Sox2 is required for embryonic development of the ventral telencephalon through the activation of the ventral determinants Nkx2.1 and Shh. Development 140, 1250-1261.

Festuccia, N., Osorno, R., Wilson, V., and Chambers, I. (2013). The role of pluripotency gene regulatory network components in mediating transitions between pluripotent cell states. Curr. Opin. Genet. Dev. 23, 504-511.

Gardner, B.L. (1982). Investigation of cell lineage and differentiation in the extraembryonic endoderm of the mouse embryo. Embryol. Exp. Morph 68, 175198.

Gardner, R.L. (1968). Mouse chimeras obtained by the injection of cells into the blastocyst. Nature 220, 596-597.

Gardner, R.L., and Beddington, R.S. (1988). Multi-lineage "stem" cells in the mammalian embryo. J. Cell Sci. Suppl. 10, 11-27.

Gekas, C., Dieterlen-Lièvre, F., Orkin, S.H., and Mikkola, H.K.A. (2005). The 
placenta is a niche for hematopoietic stem cells. Dev. Cell 8, 365-375.

Gerbe, F., Cox, B., Rossant, J., and Chazaud, C. (2008). Dynamic expression of Lrp2 pathway members reveals progressive epithelial differentiation of primitive endoderm in mouse blastocyst. Dev. Biol. 313, 594-602.

Ginhoux, F., and Guilliams, M. (2016). Tissue-Resident Macrophage Ontogeny and Homeostasis. Immunity 44, 439-449.

Glanville-Jones, H.C., Woo, N., and Arkell, R.M. (2013). Successful whole embryo culture with commercially available reagents. Int. J. Dev. Biol. 57, 6167.

Gouti, M., Tsakiridis, A., Wymeersch, F.J., Huang, Y., Kleinjung, J., Wilson, V., and Briscoe, J. (2014). In Vitro Generation of Neuromesodermal Progenitors Reveals Distinct Roles for Wnt Signalling in the Specification of Spinal Cord and Paraxial Mesoderm Identity. PLoS Biol. 12, e1001937.

Gouti, M., Delile, J., Stamataki, D., Wymeersch, F.J., Huang, Y., Kleinjung, J., Wilson, V., and Briscoe, J. (2017). A Gene Regulatory Network Balances Neural and Mesoderm Specification during Vertebrate Trunk Development. Dev. Cell 41, 243-261.e7.

Graham, V., Khudyakov, J., Ellis, P., and Pevny, L. (2003). SOX2 functions to maintain neural progenitor identity. Neuron 39, 749-765.

Hall, J., Guo, G., Wray, J., Eyres, I., Nichols, J., Grotewold, L., Morfopoulou, S., Humphreys, P., Mansfield, W., Walker, R., et al. (2009). Oct4 and LIF/Stat3 Additively Induce Krüppel Factors to Sustain Embryonic Stem Cell SelfRenewal. Cell Stem Cell 5, 597-609.

Hart, A.H., Hartley, L., Ibrahim, M., and Robb, L. (2004a). Identification, cloning and expression analysis of the pluripotency promoting Nanog genes in mouse and human. Dev. Dyn. 230, 187-198.

Hart, A.H., Hartley, L., Ibrahim, M., and Robb, L. (2004b). Identification, cloning and expression analysis of the pluripotency promoting Nanog genes in mouse and human. Dev. Dyn. 230, 187-198. 
Hayashi, K., Ohta, H., Kurimoto, K., Aramaki, S., and Saitou, M. (2011). Reconstitution of the Mouse Germ Cell Specification Pathway in Culture by Pluripotent Stem Cells. Cell 146, 519-532.

Heisenberg, C.-P., Tada, M., Rauch, G.-J., Saúde, L., Concha, M.L., Geisler, R., Stemple, D.L., Smith, J.C., and Wilson, S.W. (2000). Silberblick/Wnt11 mediates convergent extension movements during zebrafish gastrulation. Nature 405, 76-81.

Hemmati-Brivanlou, A., and Melton, D. (1997). Vertebrate Embryonic Cells Will Become Nerve Cells Unless Told Otherwise. Cell 88, 13-17.

Henrique, D., Abranches, E., Verrier, L., and Storey, K.G. (2015).

Neuromesodermal progenitors and the making of the spinal cord. Development 142, 2864-2875.

Heo, J., Lee, J.-S., Chu, I.-S., Takahama, Y., and Thorgeirsson, S.S. (2005). Spontaneous differentiation of mouse embryonic stem cells in vitro:

Characterization by global gene expression profiles. Biochem. Biophys. Res. Commun. 332, 1061-1069.

Hiramatsu, R., Matsuoka, T., Kimura-Yoshida, C., Han, S.-W., Mochida, K., Adachi, T., Takayama, S., and Matsuo, I. (2013). External mechanical cues trigger the establishment of the anterior-posterior axis in early mouse embryos. Dev. Cell 27, 131-144.

Hoffman, J.A., Wu, C.-I., and Merrill, B.J. (2013a). Tcf7l1 prepares epiblast cells in the gastrulating mouse embryo for lineage specification. Development 140 , 1665-1675.

Hoffman, J.A., Wu, C.-I., and Merrill, B.J. (2013b). Tcf7l1 prepares epiblast cells in the gastrulating mouse embryo for lineage specification. Development 140, 1665-1675.

Huber, T.L., Kouskoff, V., Fehling, H.J., Palis, J., and Keller, G. (2004). Haemangioblast commitment is initiated in the primitive streak of the mouse embryo. Nature 432, 625-630. 
Irion, S., Clarke, R.L., Luche, H., Kim, I., Morrison, S.J., Fehling, H.-J., and Keller, G.M. (2010). Temporal specification of blood progenitors from mouse embryonic stem cells and induced pluripotent stem cells. Development 137, 2829-2839.

Iwafuchi-Doi, M., Yoshida, Y., Onichtchouk, D., Leichsenring, M., Driever, W., Takemoto, T., Uchikawa, M., Kamachi, Y., and Kondoh, H. (2011a). The Pou5f1/Pou3f-dependent but SoxB-independent regulation of conserved enhancer N2 initiates Sox2 expression during epiblast to neural plate stages in vertebrates. Dev. Biol. 352, 354-366.

Iwafuchi-Doi, M., Yoshida, Y., Onichtchouk, D., Leichsenring, M., Driever, W., Takemoto, T., Uchikawa, M., Kamachi, Y., and Kondoh, H. (2011b). The Pou5f1/Pou3f-dependent but SoxB-independent regulation of conserved enhancer N2 initiates Sox2 expression during epiblast to neural plate stages in vertebrates. Dev. Biol.

Iwafuchi-Doi, M., Matsuda, K., Murakami, K., Niwa, H., Tesar, P.J., Aruga, J., Matsuo, I., and Kondoh, H. (2012). Transcriptional regulatory networks in epiblast cells and during anterior neural plate development as modeled in epiblast stem cells. Development 139, 3926-3937.

Johnson, W.E., Li, C., and Rabinovic, A. (2007). Adjusting batch effects in microarray expression data using empirical Bayes methods. Biostatistics 8 , 118-127.

Joo, J.Y., Choi, H.W., Kim, M.J., Zaehres, H., Tapia, N., Stehling, M., Jung, K.S., Do, J.T., and Schöler, H.R. (2014). Establishment of a primed pluripotent epiblast stem cell in FGF4-based conditions. Sci. Rep. 4.

Kalkan, T., and Smith, A. (2014). Mapping the route from naive pluripotency to lineage specification. Philos. Trans. R. Soc. Lond. B. Biol. Sci. 369, 20130540-.

Kinder, S.J., Tsang, T.E., Quinlan, G. a, Hadjantonakis, a K., Nagy, a, and Tam, P.P. (1999). The orderly allocation of mesodermal cells to the extraembryonic structures and the anteroposterior axis during gastrulation of the mouse embryo. Development 126, 4691-4701. 
Kohler, E.E., Cowan, C.E., Chatterjee, I., Malik, A.B., and Wary, K.K. (2011). NANOG induction of fetal liver kinase-1 (FLK1) transcription regulates endothelial cell proliferation and angiogenesis. Blood 117, 1761-1769.

Koo, B.-K., and Huch, M. (2016). Organoids: A new in vitro model system for biomedical science and disease modelling and promising source for cell-based transplantation. Dev. Biol. 420, 197-198.

Kuvardina, O.N., Herglotz, J., Kolodziej, S., Kohrs, N., Herkt, S., Wojcik, B., Oellerich, T., Corso, J., Behrens, K., Kumar, A., et al. (2015). RUNX1 represses the erythroid gene expression program during megakaryocytic differentiation. Blood 125, 3570-3579.

Lawson, K.A., Meneses, J.J., and Pedersen, R.A. (1991). Clonal analysis of epiblast fate during germ layer formation in the mouse embryo. Development 113.

Li, B., and Dewey, C.N. (2011). RSEM: accurate transcript quantification from RNA-Seq data with or without a reference genome. BMC Bioinformatics 12, 323.

Lopez-Jimenez, E., Sainz de Aja, J., Rouco, R., Victorino, J., Santos, E., BadiaCareaga, C., Rollan, I., Acemel, R.D., Torroja, C., Andres-Leon, E., et al. Pluripotency factors control the onset of Hox cluster activation in the early embryo.

Lux, C.T., Yoshimoto, M., McGrath, K., Conway, S.J., Palis, J., and Yoder, M.C. (2008). All primitive and definitive hematopoietic progenitor cells emerging before E10 in the mouse embryo are products of the yolk sac. Blood 111, 34353438.

Mainland, D. (1932). The Early Development of the Ferret: The Zona Granulosa, Zona Pellucida and Associated Structures. J. Anat. 66, 586-601.

Mangold, O., and Spemann, H. (1927). Über Induktion von Medullarplatte durch Medullarplatte im Jüngeren Keim, ein Beispiel homöogenetischer oder assimilatorischer Induktion. Wilhelm Roux. Arch. Entwickl. Mech. Org. 111, 341-422. 
Marson, A., Levine, S.S., Cole, M.F., Frampton, G.M., Brambrink, T., Johnstone, S., Guenther, M.G., Johnston, W.K., Wernig, M., Newman, J., et al. (2008). Connecting microRNA genes to the core transcriptional regulatory circuitry of embryonic stem cells. Cell 134, 521-533.

Martin, G.R. (1981a). Isolation of a pluripotent cell line from early mouse embryos cultured in medium conditioned by teratocarcinoma stem cells. Proc Natl Acad Sci U S A 78, 7634-7638.

Martin, G.R. (1981b). Isolation of a pluripotent cell line from early mouse embryos cultured in medium conditioned by teratocarcinoma stem cells. Proc. Natl. Acad. Sci. 78, 7634-7638.

Martin, M. (2011). Cutadapt removes adapter sequences from high-throughput sequencing reads. EMBnet.journal 17, 10.

Martin Gonzalez, J., Morgani, S.M., Bone, R.A., Bonderup, K., Abelchian, S., Brakebusch, C., and Brickman, J.M. (2016). Embryonic Stem Cell Culture Conditions Support Distinct States Associated with Different Developmental Stages and Potency. Stem Cell Reports 7, 177-191.

Martín-Gayo, E., González-García, S., García-León, M.J., Murcia-Ceballos, A., Alcain, J., García-Peydró, M., Allende, L., de Andrés, B., Gaspar, M.L., and Toribio, M.L. (2017). Spatially restricted JAG1-Notch signaling in human thymus provides suitable DC developmental niches. J. Exp. Med. 214, jem.20161564.

Masui, S., Nakatake, Y., Toyooka, Y., Shimosato, D., Yagi, R., Takahashi, K., Okochi, H., Okuda, A., Matoba, R., Sharov, A.A., et al. (2007). Pluripotency governed by Sox2 via regulation of Oct3/4 expression in mouse embryonic stem cells. Nat. Cell Biol. 9, 625-635.

Medvinsky, A., and Dzierzak, E. (1996). Definitive hematopoiesis is autonomously initiated by the AGM region. Cell 86, 897-906.

Mendjan, S., Mascetti, V.L., Ortmann, D., Ortiz, M., Karjosukarso, D.W., Ng, Y., Moreau, T., and Pedersen, R.A. (2014). Cell Stem Cell Article NANOG and CDX2 Pattern Distinct Subtypes of Human Mesoderm during Exit from Pluripotency. Stem Cell 15, 310-325. 
Mimoto, M.S., Kwon, S., Green, Y.S., Goldman, D., and Christian, J.L. (2015). GATA2 regulates Wnt signaling to promote primitive red blood cell fate. Dev. Biol. 407, 1-11.

Mistri, T.K., Devasia, A.G., Chu, L.T., Ng, W.P., Halbritter, F., Colby, D., Martynoga, B., Tomlinson, S.R., Chambers, I., Robson, P., et al. (2015). Selective influence of Sox2 on POU transcription factor binding in embryonic and neural stem cells. EMBO Rep. 16, 1177-1191.

Mitsui, K., Tokuzawa, Y., Itoh, H., Segawa, K., Murakami, M., Takahashi, K., Maruyama, M., Maeda, M., and Yamanaka, S. (2003a). The Homeoprotein Nanog Is Required for Maintenance of Pluripotency in Mouse Epiblast and ES Cells. Cell 113, 631-642.

Mitsui, K., Tokuzawa, Y., Itoh, H., Segawa, K., Murakami, M., Takahashi, K., Maruyama, M., Maeda, M., and Yamanaka, S. (2003b). The Homeoprotein Nanog Is Required for Maintenance of Pluripotency in Mouse Epiblast and ES Cells. Cell 113, 631-642.

Mohammed, H., Hernando-Herraez, I., Savino, A., Scialdone, A., Macaulay, I., Mulas, C., Chandra, T., Voet, T., Dean, W., Nichols, J., et al. (2017a). SingleCell Landscape of Transcriptional Heterogeneity and Cell Fate Decisions during Mouse Early Gastrulation. Cell Rep. 20, 1215-1228.

Mohammed, H., Hernando-Herraez, I., Savino, A., Scialdone, A., Macaulay, I., Mulas, C., Chandra, T., Voet, T., Dean, W., Nichols, J., et al. (2017b). SingleCell Landscape of Transcriptional Heterogeneity and Cell Fate Decisions during Mouse Early Gastrulation. Cell Rep. 20, 1215-1228.

Morgani, S.M., and Brickman, J.M. (2014). The molecular underpinnings of totipotency. Philos. Trans. R. Soc. Lond. B. Biol. Sci. 369, 20130549-.

Morgani, S., Nichols, J., and Hadjantonakis, A.-K. (2017). The many faces of Pluripotency: in vitro adaptations of a continuum of in vivo states. BMC Dev. Biol. 17, 7.

Morgani, S.M., Metzger, J.J., Nichols, J., Siggia, E.D., and Hadjantonakis, A.-K. (2018). Micropattern differentiation of mouse pluripotent stem cells recapitulates 
embryo regionalized cell fate patterning. Elife 7 .

Motosugi, N. (2005). Polarity of the mouse embryo is established at blastocyst and is not prepatterned. Genes Dev. 19, 1081-1092.

Muñoz-Sanjuán, I., and Brivanlou, A.H. (2002). Neural induction, the default model and embryonic stem cells. Nat. Rev. Neurosci. 3, 271-280.

Murakami, K., Günesdogan, U., Zylicz, J.J., Tang, W.W.C., Sengupta, R., Kobayashi, T., Kim, S., Butler, R., Dietmann, S., and Surani, M.A. (2016). NANOG alone induces germ cells in primed epiblast in vitro by activation of enhancers. Nature 529, 403-407.

Myers, C.T., and Krieg, P. a (2013). BMP-mediated specification of the erythroid lineage suppresses endothelial development in blood island precursors. Blood 122, 3929-3939.

Nagy, A., Vintersten, K., Gertsenetein, M., and Behringer, R. (2014). Manipulating the Mouse Embryo: A Laboratory Manual, Fourth Edition.

Navarro, P., Festuccia, N., Colby, D., Gagliardi, A., Mullin, N.P., Zhang, W., Karwacki-Neisius, V., Osorno, R., Kelly, D., Robertson, M., et al. (2012). OCT4/SOX2-independent Nanog autorepression modulates heterogeneous Nanog gene expression in mouse ES cells. EMBO J. 31, 4547-4562.

Nichols, J., and Smith, A. (2009a). Naive and Primed Pluripotent States. Cell Stem Cell 4, 487-492.

Nichols, J., and Smith, A. (2009b). Naive and Primed Pluripotent States. Cell Stem Cell 4, 487-492.

Nichols, J., Zevnik, B., Anastassiadis, K., Niwa, H., Klewe-Nebenius, D., Chambers, I., Scholer, H., and Smith, A. (1998). Formation of pluripotent stem cells in the mammalian embryo depends on the POU transcription factor Oct4. Cell 95, 379-391.

Nieto, M.A. (2013). Epithelial plasticity: a common theme in embryonic and cancer cells. Science 342, 1234850. 
Nieto, M.A., Sargent, M.G., Wilkinson, D.G., and Cooke, J. (1994). Control of cell behavior during vertebrate development by Slug, a zinc finger gene.

Science 264, 835-839.

Niwa, H. (2007). How is pluripotency determined and maintained? Development 134, 635-646.

Niwa, H., Miyazaki, J., and Smith, A.G. (2000). Quantitative expression of Oct$3 / 4$ defines differentiation, dedifferentiation or self-renewal of ES cells. Nat. Genet. 24, 372-376.

O'Donnell, M., Hong, C.-S., Huang, X., Delnicki, R.J., and Saint-Jeannet, J.-P. (2006). Functional analysis of Sox8 during neural crest development in Xenopus. Development 133, 3817-3826.

Okuda, A., Fukushima, A., Nishimoto, M., Orimo, A., Yamagishi, T., Nabeshima, Y., Kuro-o, M., Nabeshima, Y., Boon, K., Keaveney, M., et al. (1998). UTF1, a novel transcriptional coactivator expressed in pluripotent embryonic stem cells and extra-embryonic cells. EMBO J. 17, 2019-2032.

Osorno, R., Tsakiridis, A., Wong, F., Cambray, N., Economou, C., Wilkie, R., Blin, G., Scotting, P.J., Chambers, I., and Wilson, V. (2012a). The developmental dismantling of pluripotency is reversed by ectopic Oct4 expression. Development 139, 2288-2298.

Osorno, R., Tsakiridis, A., Wong, F., Cambray, N., Economou, C., Wilkie, R., Blin, G., Scotting, P.J., Chambers, I., and Wilson, V. (2012b). The developmental dismantling of pluripotency is reversed by ectopic Oct4 expression. Development 139, 2288-2298.

Padrón-Barthe, L., Temiño, S., Villa Del Campo, C., Carramolino, L., Isern, J., and Torres, M. (2014). Clonal analysis identifies hemogenic endothelium and not hemangioblasts as the source of the blood-endothelial common lineage in the mouse embryo.

Palis, J., Robertson, S., Kennedy, M., Wall, C., and Keller, G. (1999). Development of erythroid and myeloid progenitors in the yolk sac and embryo proper of the mouse. Development 126, 5073-5084. 
Paralkar, V.R., Mishra, T., Luan, J., Yao, Y., Kossenkov, A. V., Anderson, S.M., Dunagin, M., Pimkin, M., Gore, M., Sun, D., et al. (2014). Lineage and speciesspecific long noncoding RNAs during erythro-megakaryocytic development. Blood 123, 1927-1937.

Parfitt, D.-E., and Shen, M.M. (2014). From blastocyst to gastrula: gene regulatory networks of embryonic stem cells and early mouse embryogenesis. Philos. Trans. R. Soc. Lond. B. Biol. Sci. 369.

Pfeuty, B., Kress, C., and Pain, B. (2018). Network Features and Dynamical Landscape of Naive and Primed Pluripotency. Biophys. J. 114, 237-248.

Pfister, S., Steiner, K.A., and Tam, P.P.L. (2007). Gene expression pattern and progression of embryogenesis in the immediate post-implantation period of mouse development. Gene Expr. Patterns 7, 558-573.

Piazzolla, D., Palla, A.R., Pantoja, C., Cañamero, M., de Castro, I.P., Ortega, S., Gómez-López, G., Dominguez, O., Megías, D., Roncador, G., et al. (2014). Lineage-restricted function of the pluripotency factor NANOG in stratified epithelia. Nat. Commun. 5, 4226.

Porcher, C., Swat, W., Rockwell, K., Fujiwara, Y., Alt, F.W., and Orkin, S.H. (1996). The T cell leukemia oncoprotein SCL/tal-1 is essential for development of all hematopoietic lineages. Cell $86,47-57$.

Porcher, C., Chagraoui, H., and Kristiansen, M.S. (2017). SCL/TAL1: a multifaceted regulator from blood development to disease. Blood 129, 20512060.

Pratt, H.P.M., Ziomek, C.A., Reeve, W.J.D., and Johnson, A.M.H. (1982). Compaction of the mouse embryo: an analysis of its components. Embryol. Exp. Morph 70, 113-132.

Radzisheuskaya, A., Chia, G.L. Bin, dos Santos, R.L., Theunissen, T.W., Castro, L.F.C., Nichols, J., and Silva, J.C.R. (2013). A defined Oct4 level governs cell state transitions of pluripotency entry and differentiation into all embryonic lineages. Nat. Cell Biol. 15. 
Reichenbach, B., Delalande, J.-M., Kolmogorova, E., Prier, A., Nguyen, T., Smith, C.M., Holzschuh, J., and Shepherd, I.T. (2008). Endoderm-derived Sonic hedgehog and mesoderm Hand2 expression are required for enteric nervous system development in zebrafish. Dev. Biol. 318, 52-64.

Robertson, S.M., Kennedy, M., Shannon, J.M., and Keller, G. (2000). A transitional stage in the commitment of mesoderm to hematopoiesis requiring the transcription factor SCL/tal-1. Development 127, 2447-2459.

Robinson, M.D., McCarthy, D.J., and Smyth, G.K. (2010). edgeR: a Bioconductor package for differential expression analysis of digital gene expression data. Bioinformatics 26, 139-140.

Rossant, J., and Tam, P.P.L. (2009). Blastocyst lineage formation, early embryonic asymmetries and axis patterning in the mouse. Development 136, 701-713.

Rous, P. (1911). The relations of embryonic tissue and tumor in mixed grafts. J. Exp. Med. 13, 239-247.

Runner, M.N. (1947). Development of mouse eggs in the anterior chamber of the eye. Anat. Rec. 98, 1-17.

Sánchez-Sánchez, A.V., Camp, E., Leal-Tassias, A., Atkinson, S.P., Armstrong, L., Díaz-Llopis, M., and Mullor, J.L. (2010). Nanog regulates primordial germ cell migration through Cxcr4b. Stem Cells 28, 1457-1464.

Scialdone, A., Tanaka, Y., Jawaid, W., Moignard, V., Wilson, N.K., Macaulay, I.C., Marioni, J.C., and Göttgens, B. (2016). Resolving early mesoderm diversification through single-cell expression profiling. Nature 535, 289-293.

Shalaby, F., Rossant, J., Yamaguchi, T.P., Gertsenstein, M., Wu, X.-F., Breitman, M.L., and Schuh, A.C. (1995). Failure of blood-island formation and vasculogenesis in Flk-1-deficient mice. Nature 376, 62-66.

Sherwood, R.I., Jitianu, C., Cleaver, O., Shaywitz, D.A., Lamenzo, J.O., Chen, A.E., Golub, T.R., and Melton, D.A. (2007). Prospective isolation and global gene expression analysis of definitive and visceral endoderm. Dev. Biol. 304, 
$541-555$.

Shivdasani, R.A., Mayer, E.L., and Orkin, S.H. (1995). Absence of blood formation in mice lacking the T-cell leukaemia oncoprotein tal-1/SCL. Nature $373,432-434$.

Skerjanc, I.S., Petropoulos, H., Ridgeway, A.G., and Wilton, S. Myocyte Enhancer Factor 2C and Nkx2-5 Up-regulate Each Other's Expression and Initiate Cardiomyogenesis in P19 Cells*.

Socolovsky, M., Nam, H., Fleming, M.D., Haase, V.H., Brugnara, C., and Lodish, H.F. (2001). Ineffective erythropoiesis in Stat5a(-/-)5b(-/-) mice due to decreased survival of early erythroblasts. Blood 98, 3261-3273.

Stryjewska, A., Dries, R., Pieters, T., Verstappen, G., Conidi, A., Coddens, K., Francis, A., Umans, L., van IJcken, W.F.J., Berx, G., et al. (2017). Zeb2 Regulates Cell Fate at the Exit from Epiblast State in Mouse Embryonic Stem Cells. Stem Cells 35, 611-625.

Sun, L.T., Yamaguchi, S., Hirano, K., Ichisaka, T., Kuroda, T., and Tada, T. (2014). Nanog co-regulated by Nodal/Smad2 and Oct4 is required for pluripotency in developing mouse epiblast. Dev. Biol. 392, 182-192.

Tam, P.P.., and Behringer, R.R. (1997). Mouse gastrulation: the formation of a mammalian body plan. Mech. Dev. 68, 3-25.

Tam, P.P., and Beddington, R.S. (1987). The formation of mesodermal tissues in the mouse embryo during gastrulation and early organogenesis.

Development 99.

Tam, P.P.L., and Zhou, S.X. (1996). The Allocation of Epiblast Cells to Ectodermal and Germ-Line Lineages Is Influenced by the Position of the Cells in the Gastrulating Mouse Embryo. Dev. Biol. 178, 124-132.

Tanaka, Y., Era, T., Nishikawa, S., and Kawamata, S. (2007). Forced expression of Nanog in hematopoietic stem cells results in a gammadeltaT-cell disorder. Blood 110, 107-115.

Tarafdar, A., Dobbin, E., Corrigan, P., Freeburn, R., and Wheadon, H. (2013). 
Canonical Wnt signaling promotes early hematopoietic progenitor formation and erythroid specification during embryonic stem cell differentiation. PLoS One 8 , e81030.

Tay, Y., Zhang, J., Thomson, A.M., Lim, B., and Rigoutsos, I. (2008).

MicroRNAs to Nanog, Oct4 and Sox2 coding regions modulate embryonic stem cell differentiation. Nature 455, 1124-1128.

Teo, A., Arnold, S., Trotter, M., Brown, S., and Ang, L. (2011). Pluripotency factors regulate definitive endoderm specification through eomesodermin. Genes Dev 25.

Tesar, P.J., Chenoweth, J.G., Brook, F.A., Davies, T.J., Evans, E.P., Mack, D.L., Gardner, R.L., and McKay, R.D.G. (2007). New cell lines from mouse epiblast share defining features with human embryonic stem cells. Nature 448 , 196-199.

Thiery, J.P., Acloque, H., Huang, R.Y.J., and Nieto, M.A. (2009). EpithelialMesenchymal Transitions in Development and Disease. Cell 139, 871-890.

Thomson, M., Liu, S.J., Zou, L.-N., Smith, Z., Meissner, A., and Ramanathan, S. (2011). Pluripotency Factors in Embryonic Stem Cells Regulate Differentiation into Germ Layers. Cell 145, 875-889.

Tober, J., Koniski, A., McGrath, K.E., Vemishetti, R., Emerson, R., De MesyBentley, K.K.L., Waugh, R., and Palis, J. (2007). The megakaryocyte lineage originates from hemangioblast precursors and is an integral component both of primitive and of definitive hematopoiesis. Blood 109, 1433-1441.

Tober, J., McGrath, K.E., and Palis, J. (2008). Primitive erythropoiesis and megakaryopoiesis in the yolk sac are independent of c-myb. Blood 111, 26362639.

Trott, J., and Martinez Arias, A. (2013). Single cell lineage analysis of mouse embryonic stem cells at the exit from pluripotency. Biol. Open 2, 1049-1056.

Turner, D., Alonso-Crisostomo, L., Girgin, M., Baillie-Johnson, P., Glodowski, C.R., Hayward, P.C., Collignon, J., Gustavsen, C., Serup, P., Steventon, B., et 
al. (2017). Gastruloids develop the three body axes in the absence of extraembryonic tissues and spatially localised signalling. bioRxiv.

Waddington, C.H. (1933). Induction by the endoderm in birds. Wilhelm Roux' Arch. Für Entwicklungsmechanik Der Org. 128, 502-521.

Waddington, C.H. (1940). Organisers and genes (Cambridge university press).

Wang, Z., Oron, E., Nelson, B., Razis, S., and Ivanova, N. (2012). Distinct Lineage Specification Roles for NANOG, OCT4, and SOX2 in Human Embryonic Stem Cells. Cell Stem Cell 10, 440-454.

Wilkinson, D.G., Bailes, J.A., Champion, J.E., and McMahon, A.P. (1987). A molecular analysis of mouse development from 8 to 10 days post coitum detects changes only in embryonic globin expression. Development 99, 493500.

Winklbauer, R., Medina, A., Swain, R.K., and Steinbeisser, H. (2001). Frizzled-7 signalling controls tissue separation during Xenopus gastrulation. Nature 413, 856-860.

Yagi, R., Kohn, M.J., Karavanova, I., Kaneko, K.J., Vullhorst, D., DePamphilis, M.L., and Buonanno, A. (2007). Transcription factor TEAD4 specifies the trophectoderm lineage at the beginning of mammalian development. Development 134, 3827-3836.

Yamaguchi, S., Kurimoto, K., Yabuta, Y., Sasaki, H., Nakatsuji, N., Saitou, M., and Tada, T. (2009). Conditional knockdown of Nanog induces apoptotic cell death in mouse migrating primordial germ cells. Development 136, 4011-4020. Yeom, Y.I., Fuhrmann, G., Ovitt, C.E., Brehm, A., Ohbo, K., Gross, M., Hübner, K., and Schöler, H.R. (1996). Germline regulatory element of Oct-4 specific for the totipotent cycle of embryonal cells. Development 122, 881-894.

Ying, Q.-L., Nichols, J., Chambers, I., and Smith, A. (2003). BMP Induction of Id Proteins Suppresses Differentiation and Sustains Embryonic Stem Cell SelfRenewal in Collaboration with STAT3. Cell 115, 281-292.

Yokomizo, T., Hasegawa, K., Ishitobi, H., Osato, M., Ema, M., Ito, Y., 
Yamamoto, M., and Takahashi, S. (2008). Runx1 is involved in primitive erythropoiesis in the mouse. Blood 111.

Yoshimizu, T., Obinata, M., and Matsui, Y. (2001). Stage-specific tissue and cell interactions play key roles in mouse germ cell specification. Development 128.

Yoshimoto, M., Montecino-Rodriguez, E., Ferkowicz, M.J., Porayette, P., Shelley, W.C., Conway, S.J., Dorshkind, K., and Yoder, M.C. (2011). Embryonic day 9 yolk sac and intra-embryonic hemogenic endothelium independently generate a B-1 and marginal zone progenitor lacking B-2 potential. Proc. Natl. Acad. Sci. 108, 1468-1473.

Zhang, J., Socolovsky, M., Gross, A.W., and Lodish, H.F. (2003). Role of Ras signaling in erythroid differentiation of mouse fetal liver cells: functional analysis by a flow cytometry-based novel culture system. Blood 102, 3938-3946.

Zhang, M., Leitch, H.G., Tang, W.W.C., Festuccia, N., Hall-Ponsele, E., Nichols, J., Surani, M.A., Smith, A., and Chambers, I. (2018). Esrrb Complementation Rescues Development of Nanog-Null Germ Cells.

Zhu, Q., Song, L., Peng, G., Sun, N., Chen, J., Zhang, T., Sheng, N., Tang, W., Qian, C., Qiao, Y., et al. (2014). The transcription factor Pou3f1 promotes neural fate commitment via activation of neural lineage genes and inhibition of external signaling pathways. Elife 3.

Zwart, R., Broos, L., Grosveld, G., and Meijer, D. (1996). The restricted expression pattern of the POU factor Oct- 6 during early development of the mouse nervous system. Mech. Dev. 54, 185-194. 



\section{PUBLICATIONS}

The work described in this thesis is included in the following manuscripts:

- Julio Sainz de Aja, Sergio Menchero, Isabel Rollan, Wajid Jawaid, Antonio Barral, Gonzalo Carreño-Tarragona, Claudio Badia-Careaga, Jennifer Nichols, Berthold Göttgens, Joan Isern, and Miguel Manzanares (2018). Control of primitive hematopoiesis by the pluripotency factor NANOG that directly regulates Tal1. (second revision in EMBO J).

- Julio Sainz de Aja* ${ }^{*}$, Antonio Barral*, Isabel Rollan*, Hector Sanchez Iranzo, Wajid Jawaid, Claudio Badia-Careaga, Inmaculada Ors, Sergio Menchero, Miguel Manzanares (2018). Nanog repress anterior-neural fate through Pou3f1 at the exit of pluripotency both in vitro and in vivo. (in preparation; *equal contribution).

The collaboration in other research projects during the development of the thesis has resulted in the following publications:

- Sergio Menchero, Julio Sainz de Aja, Miguel Manzanares (2018). Our first choice: cellular and genetic underpinnings of trophectoderm identity and differentiation in the mammalian embryo. Curr Top Dev Biol 128:5980 .

- Elena Lopez-Jimenez*, Julio Sainz de Aja*, Raquel Rouco\#, Jesus Victorino\#, Elisa Santos\#, Claudio Badia-Careaga, Isabel Rollan, Rafael D. Acemel, Carlos Torroja, Eduardo Andres-Leon, Jose Luis Gomez-Skarmeta, Giovanna Giovinazzo, Fatima Sanchez-Cabo and Miguel Manzanares (2018). Pluripotency factors control the onset of Hox cluster activation in the early embryo. (under review Cell Rep; ${ }^{*}$ equal contribution).

- Héctor Sánchez-Iranzo, María Galardi-Castilla, Andrés Sanz-Morejón, Juan Manuel González-Rosa, Ricardo Costa, Alexander Ernst, Julio Sainz de Aja, Xavier Langa, and Nadia Mercader (2018). Transient fibrosis resolves via fibroblast inactivation in the regenerating zebrafish heart. Proc Natl Acad Sci U S A 115, 4188-93. 


